OAK RIDGE NATIONAL LABOPATORY

MARTIN MARIETTA

\title{
Soils of Walker Branch Watershed
}

Environmental Sciences Division

Publication No. 3535

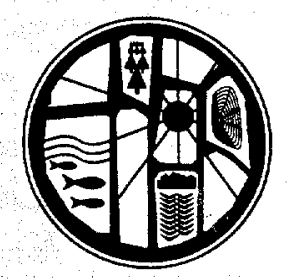

MANAGED BY

MARTII MARIETTA ENERGY SYSTEMS, INC. FOR THE UNIEO STATES

DEPARTMENT OF ENERGY 
This report has been reproduced directly from the best available copy.

Available to DOE and DOE contractors from the Office of Scientific and Technical Information, P.O. Box 62, Oak Ridge, TN 37631; prices available from (615) 5766401, FTS 6266401.

Available to the public from the National Technical Information Service, U.S. Department of Commerce, 5265 Port Royal Rd., Springfield, VA 22161.

This report was prepared as an account of work sponsored by an agency of the United States Government. Neither the United States Government nor any agency thereof, nor any of their employees, makes any warranty, express or implied, or assumes any legal liability or responsibility for the accuracy, completeness, or usefulness of any information, apparatus, product, or process disclosed, or represents that its use would not infringe privately owned rights. Reference herein to any specific commercial product, process, or service by trade name, trademark, manufacturer, or otherwise, does not necessarily constitute or imply its endorsement, recommendation, or favoring by the United States Government or any agency thereof. The views and opinions of authors expressed herein do not necessarily state or reflect those of the United States Government or any agency thereof. 
ORNL/TM-11606

\title{
ENVIRONMENTAL SCIENCES DIVISION
}

\section{SOILS OF WALKER BRANCH WATERSHED}

\author{
D. A. Lietzke' \\ Lietzke Soil Services \\ Route 3, Box 607 \\ Rutledge, Tennessee 37661 \\ 'Subcontractor \\ Environmental Sciences Division \\ Publication No. 3535 \\ Date Published - March 1994
}

\author{
Prepared by the \\ OAK RIDGE NATIONAL LABORATORY \\ Oak Ridge, Tennessee 37831-6285 \\ managed by \\ MARTIN MARIETTA ENERGY SYSTEMS, INC. \\ for the \\ U.S. DEPARTMENT OF ENERGY \\ under Contract No. DE-AC05-84OR21400
}


TABLE OF CONTENTS

Paae

LIST OF FIGURES $\ldots \ldots \ldots \ldots \ldots \ldots \ldots \ldots \ldots \ldots$

UST OF TABLES $\ldots \ldots \ldots \ldots \ldots \ldots \ldots \ldots \ldots \ldots \ldots \ldots \ldots \ldots \ldots$

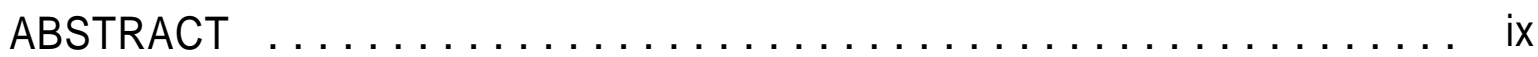

1. INTRODUCTION . . . . . . . . . . . . . . . . . . . 1

2 SITE DESCRIPTION: GEOLOGIC AND GEOMORPHIC SETTING ..... 5

21 SURFICIAL GEOLOGY

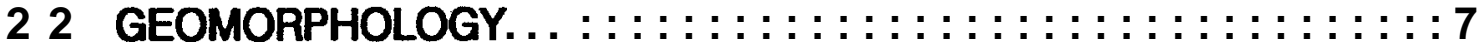

221 Geomorphic History $\ldots \ldots \ldots \ldots \ldots \ldots \ldots \ldots \ldots \ldots$

222 Modem Age Geomorphic Processes ............. 15

223 Holocene Geomorphic Processes ............. 19

224 Pleistocene Geomorphic Processes . . . . . . . . . . 19

225 Early Pleiiocene and Late Tertiary Geomorphic Processes . 20

23 KARST GEOMORPHOLOGY . . . . . . . . . . . . . . . 26

3. TECHNICAL APPROACH TO SOIL MAPPING $\ldots \ldots \ldots \ldots \ldots \ldots 29$

4. WALKER BRANCH WATERSHED SOIL CODING LEGEND . . . . . . 33

4.1 SOIL IDENTIFICATION LEGEND $\ldots \ldots \ldots \ldots \ldots \ldots \ldots .34$

4.2 DESCRIPTIONS OF KNOX GROUP; SOILS AND LANDFORMS : : : 37

4.21 Knox Group Residual Soils . . . . . . . . . . . . . . . . . . 36

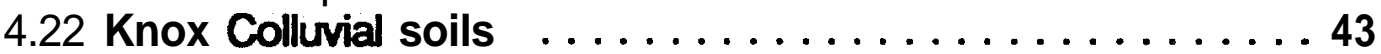

423 Doline Soils . . . . . . . . . . . . . . . . . . . . . . . . . . . 47

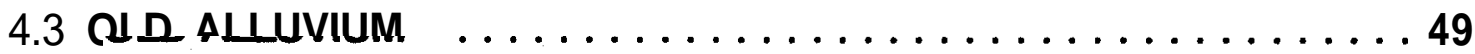

4.4 RECENT ALUUVIUM $\ldots \ldots \ldots \ldots \ldots \ldots \ldots \ldots \ldots \ldots \ldots \ldots$

5. INTERPRETATIONS $\ldots \ldots \ldots \ldots \ldots \ldots \ldots \ldots \ldots \ldots \ldots \ldots \ldots$

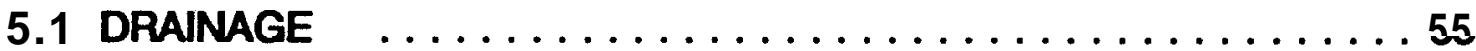

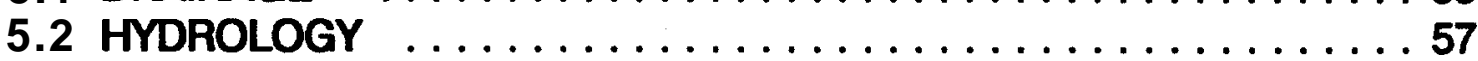

5.21 Surface Water Infiltration and Near-Surface Water Flow . . 57

52.2 Water-Flow Pathways Deeper in the Soil ..........60 60

5.23 Soil Role in Hydrologic Diige and Recharge of Perched

and Ground Water Tables . . . . . . . . . . . . . . . 60

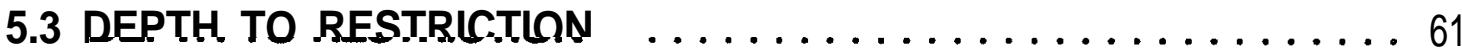

5.4 DISTURBED SOIL EROSION POTENTIAL $\ldots \ldots \ldots \ldots \ldots \ldots \ldots 61$

5.5 UNDISTURBED SOIL EROSION POTENTIAL $\ldots \ldots \ldots \ldots \ldots \ldots \ldots . \ldots 6$

5.6 SUITABIUTYY FOR PINES $\ldots \ldots \ldots \ldots \ldots \ldots \ldots \ldots \ldots \ldots \ldots$ 
TABLE OF CONTENTS (Cont'd)

Paae

5.7 RATINGS FOR HARDWOODS $\ldots \ldots \ldots \ldots \ldots \ldots \ldots \ldots \ldots \ldots 6$

5.8 RATINGS FOR PAVED ROADS AND STREETS 62

5.9 UNPAVED ROADS $\ldots \ldots \ldots \ldots \ldots \ldots \ldots \ldots:::::::::::::::$ : 63

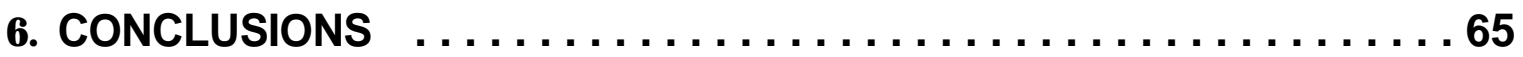

7. REFERENCES $\ldots \ldots \ldots \ldots \ldots \ldots \ldots \ldots \ldots \ldots \ldots \ldots \ldots \ldots \ldots \ldots \ldots \ldots \ldots$

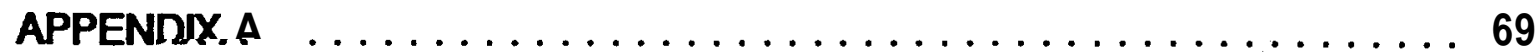

AI SOIL CLASSIFICATION $\ldots \ldots \ldots \ldots \ldots \ldots \ldots \ldots \ldots \ldots \ldots$

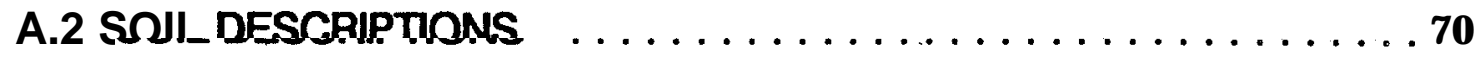

A 3 SOIL CORRELATION FROM TM-2968 $\ldots \ldots \ldots \ldots \ldots \ldots \ldots 94$ 


\section{LIST OF FIGURES}

Fiqure

Paae

1. Location map of Walker Branch Watershed on the Oak Ridge Reservation 2

2. Soil Conservation' Service soil map of Walker Branch Watershed ..... 3

3. Geologic formations and their extent on Walker Branch Watershed ... 8

4. Geomorphic terms commonly used to describe landforms ........ 9

5. Location of soil coring sites on Walker Branch Watershed ......... 11

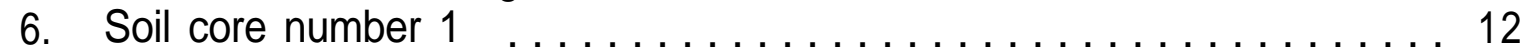

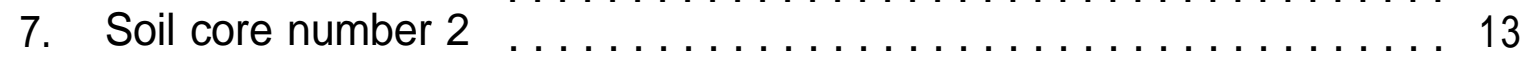

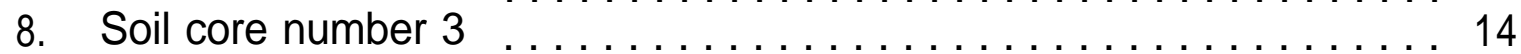

9. Pre-AEC takeover land use on Walker Branch Watershed ......... 16

10. Distribution of Pleistocene colluvium on Walker Branch Watershed ... 18

11. Topographic inversion ..................... 22

12. Topographic inversion on Chestnut Ridge . . . . . . . . . . . 23

13. Location of ancient alluvium and ancient colluvium on Walker Branch Watershed ............................ 24

14. Residual soils that occur above ancient alluvium and ancient colluvium on Walker Branch Watershed .......................... 25

15. Location of dolines on Walker Branch Watershed ............. 27

16. Silt and sand stratigraphy in East Chestnut Ridge Doline $C \ldots \ldots \ldots 28$

17. Surficial geology and soil map of Walker Branch Watershed ...... 31

18. Soil map of Walker Branch Watershed at a scale of 1:2400 (foldout) . . . . . . . . . . . . . . . . . . . . . . . . Inside Back Cover

19. Near-surface soil hydrology on Walker Branch Watershed ........ 58 

LIST OF TABLES

\section{Table}

Page

1. Soil interpretations $\ldots \ldots \ldots \ldots \ldots \ldots \ldots \ldots \ldots \ldots$ 


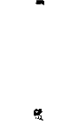


ABSTRACT

The soil survey of Walker Branch Watershed (WBW) utilized the most up-to-date knowledge of soils, geology, and geohydrology in building the soils data base needed to reinterpret past research and to begin new research in the watershed. The soils of WBW were also compared with soils mapped elsewhere along Chestnut Ridge on the Oak Ridge Reservation to (1) establish whether knowledge obtained elsewhere could be used within the watershed, (2) determine whether there were any soils restricted to the watershed, and (3) evaluate geologic formation lateral variability.

Soils, surficial geology, and geomorphology were mapped at a scale of $1: 1200$ using a paper base map having 2-ft contour intervals. Most of the contours seemed to reasonably represent actual landform configurations, except for dense wooded areas. For example, the very large dolines or sinkholes were shown on the contour base map, but numerous smaller ones were not. In addition, small drainageways and gullies were often not shown. These often small but important features were located approximately as soil mapping progressed.

WBW is underlain by dolostones of the Knox Group, but only a very small part of the surface area contains outcroppings of rock and most outcrops were located in the lower part. Soil mapping revealed the presence of both ancient alluvium and ancient colluvium deposits, not recognized in previous soil surveys, that have been preserved in high-elevation stable portions of present-day landforms. An erosional geomorphic process of topographic inversion requiring several millions of years within the Pleistocene is necessary to bring about the degree of inversion that is expressed in the watershed. Indeed, some of these ancient alluvial and colluvial remnants may date back into the Tertiary. Also evident in the watershed, and preserved in the broad, nearly level bottoms of dolines, are multiple deposits of silty material either devoid or nearly devoid of coarse fragments. Recent research indicates that most of this silty material is the result of slope wash processed during the Holocene Age.

Residual soils of the watershed were related to the underlying geologic formations by their morphology and types of chert. Colluvial soils were identified and mapped whenever the colluvium thickness exceeded 20 in. $(50 \mathrm{~cm})$. Except for the ancient colluvial soils (colluvium without a present-day source area), colluvial soils were not separated according to their geologic age, but stacked colluvial deposits are located in low footslope landforms. Colluvial soils in the watershed were identified and mapped according to their morphologic properties that would influence the perching and subsurface movement of water. Alluvial soils were restricted to present floodplains, low fan terraces, and low fan deltas. Nearly all alluvial soils contained very young surficial sediments derived from slopewash resulting from land clearing and subsequent agricultural activities. 


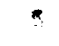




\section{INTRODUCTION}

The soil survey of Walker Branch Watershed (WBW) located on Chestnut Ridge (Fig. 1) was conducted to establish a soils base map needed for watershed research activities. The purpose of the soil survey was to determine the location and extent of all important soils on the site, to assist in the analysis of surface and near surface geohydrology, and to interpret significant soil properties that would have an effect on current and future research projects. Soil mapping (Fig. 2) of the Anderson County portion of the Oak Ridge Reservation had been done previously (Moneymaker 1981) at a scale of $1: 15840$, but the detail of that mapping was insufficient to resolve important landforms and soils that have an effect on geohydrology, especially the location of dolines, colluvial soils, and ancient alluvium. The site was previously mapped in 1967, and some characterization data were released in a 1970 publication (Peters et al. 1970). Although the 1967 mapping was made at a scale of 1:3168, none of the old alluvium was recognized, nor were the dolines delineated. However, with correlation of the soils information to current concepts and standards, much of the soils data contained in this report (Peters et al. 1970) is still useful. Earlier work elsewhere on Chestnut Ridge was also utilized in this report (Ketelle and Huff 1984; Lee, Kopp, and Lietzke 1984; Lee, Lietzke, Ketelle, and Ammons 1988). 
ORNL-DWG 92M-2043

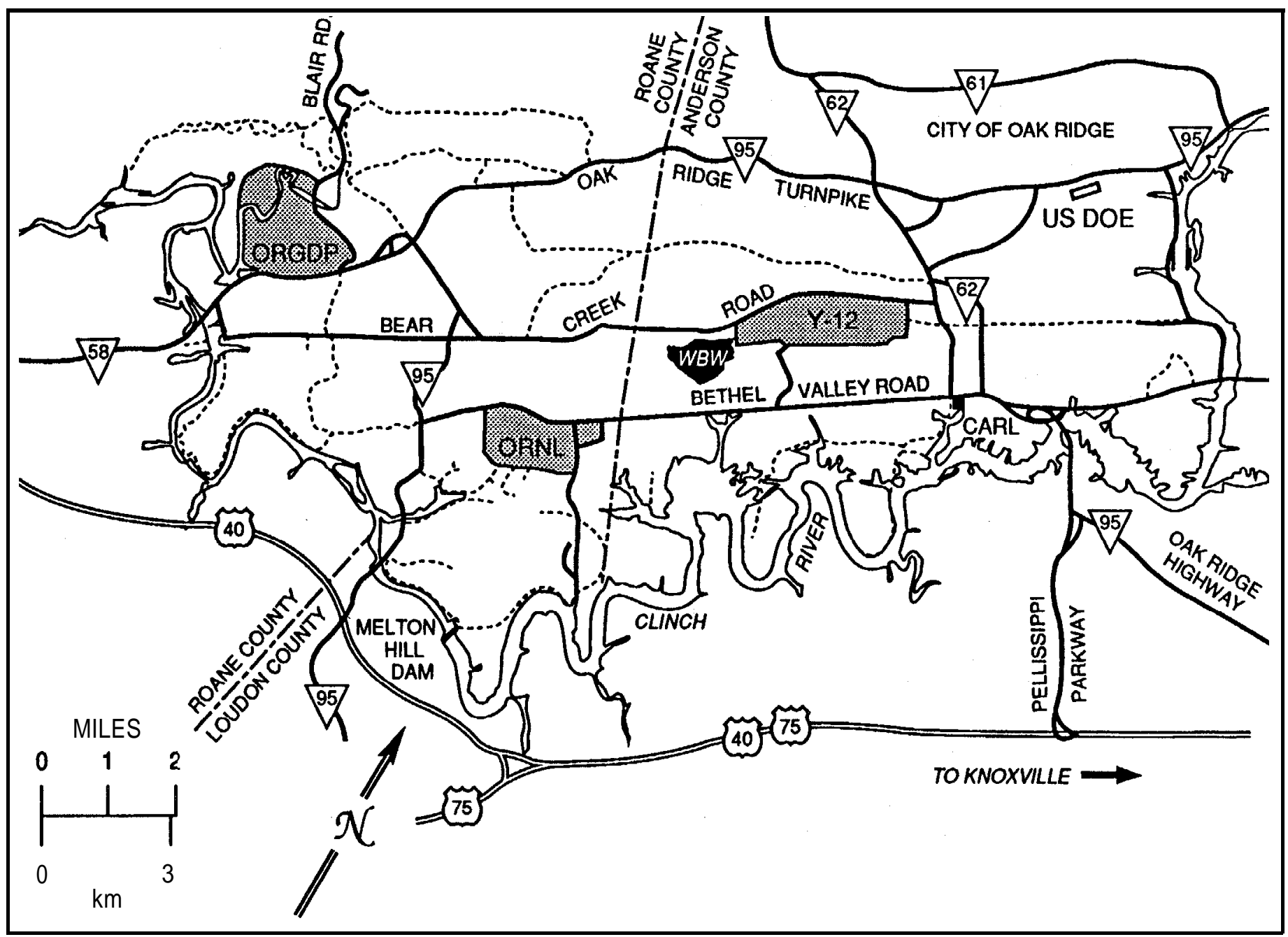

Figure 1. Location map of Walker Branch Watershed on the Oak Ridge Reservation 


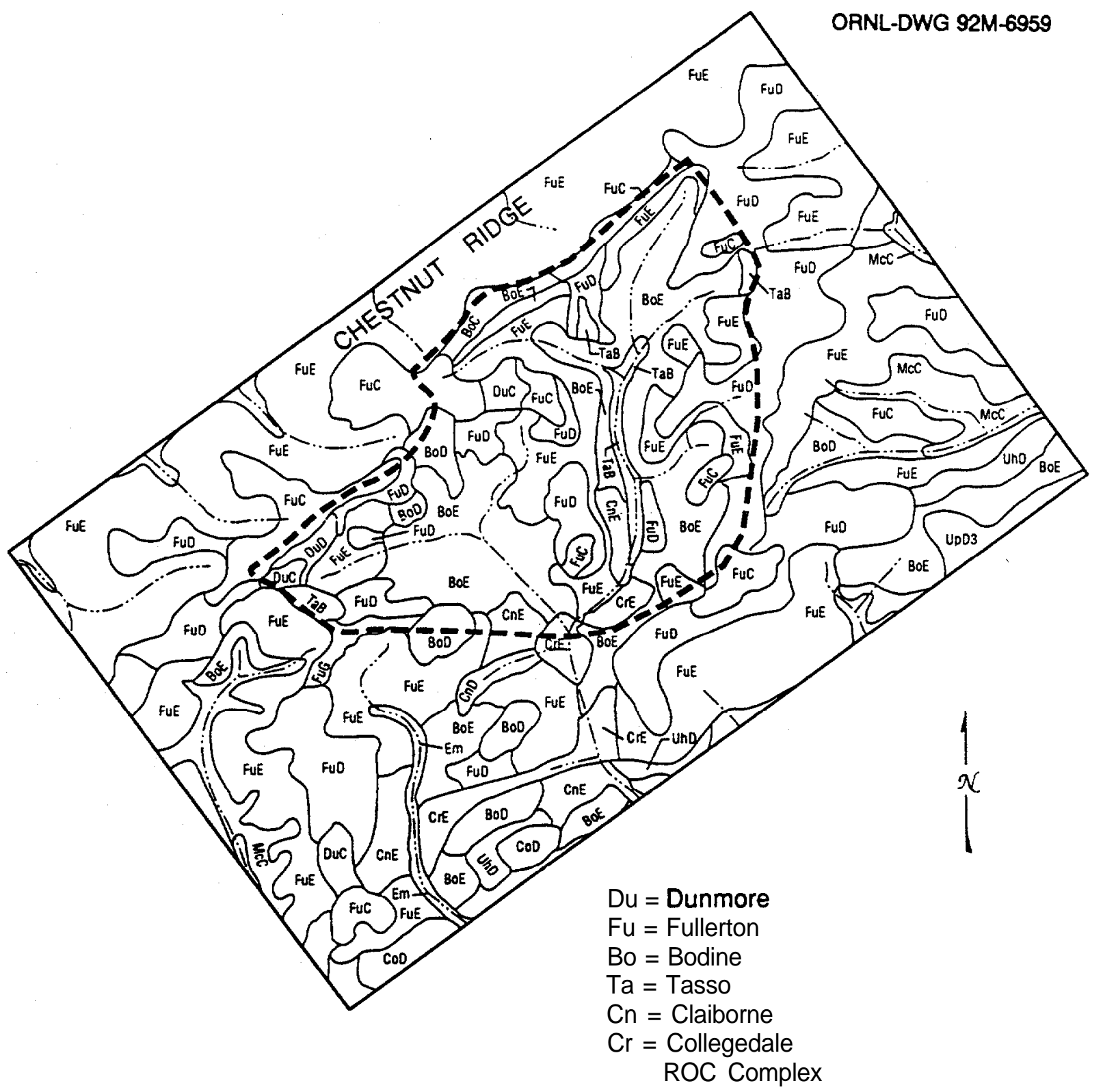

Figure 2. Soil Conservation Service soil map of Walker Branch Watershed 


\section{SITE DESCRIPTION: GEOLOGIC AND GEOMORPHIC SETTING}

WBW occupies a portion of Chestnut Ridge (Fig. 1). The boundary of the watershed generally coincides with the surface drainage divides. However, numerous dolines lie along the eastern and northern sides that seem to be outside the boundary but, in fact, may be delivering water to the watershed. The watershed is underlain by the Copper Ridge, Chepultepec, Longview, Kingsport, and Mascot formations of the Knox Group. Chemical weathering processes have transformed hard rock into saprolite, and, near the surface, soil-forming processes have transformed saprolite into distinctive soils having several pedogenic soil horizons. Imposed on the geologic formations and their residual soils are the effects of past geomorphic processes that have given rise to (1) a surficial mantle of ancient alluvium from past stream activity, (2) ancient colluvium, (3) pre-Pleistocene colluvium, and (4) Pleistocene-aged colluvium. Karst geomorphic processes have also been very active in the watershed and have given rise to the many dolines (surface depressions or sinkholes) that were identified during the soil mapping activity. Many large dolines contain silty materials that have been deposited in them one or more times during the Pleistocene and Holocene and has been preserved in the bottoms of dolines with broad shallow basins, an indication that many dolines have been stable for several thousands of years. The silty material closest to the surface has been dated at early Holocene Age.

\section{SURFICIAL GEOLOGY}

WBW is underlain on the south by the Mascot formation; in the middle by the Kingsport, Longview, and Chepultepec formations: and on the north, by the Copper Ridge formation. One major objective of the soil survey was to approximately locate the surface boundaries between every formation or member of a group. McMaster (1963) mapped the general locations of the major geologic groups of the area, but not the location of each formation within a group. Except for the Mascot formation, there were very few outcrops of hard rock. Only a few areas of ledges and pinnacles are exposed in the upper and lower Knox Group. Other rock outcrops occur in stream channels. Therefore, the characteristics of oxidized and weathered rock leached of calcium carbonate, defined here as isovolumetrically weathered saprolite, and the surficial soil morphology were used to identify the location of boundaries and extent of each major geologic formation. Characteristics of saprolite and saprolitic materials (saprolite that has undergone partial and chaotic collapse) can be drastically different from the unoxidized and unleached parent rock. The upper saprolitic materials of the Knox group, for example, consist of an acidic, high-silt and high-clay-content residue into which clay has been either translocated or neo-formed. Iron and manganese oxides are 
common but lesser components of saprolites, on which they form a coating on many fragment surfaces. Soil mapping located the boundaries and extent of the residual soils and underlying saprolite from all geologic formations wide enough to be mapped that are exposed at the surface. Substantial areas are covered by alluvium and colluvium of more than one age of deposition.

The Knox Group consists of five recognizable formations that are commonly identified by (1) their location with respect to formations above and below, (2) the type of chert they contain, and (3) their soil morphology. The youngest formation in the Knox is the Mascot. This formation generally contains subrounded jasperoid and chalcedanous chert, which is a surficial visual clue used to separate it from the younger Unit A of the Chickamauga, with its tabular chert and the older Kingsport beneath. However, geomorphic processes have scattered chert from both formations downslope across the landscape, so that one must be careful in mapping thicknesses of geologic formations by using surface lag gravel. In addition, the subsoil of the Mascot formation has its own distinctive reddish color and more-plastic rheologic properties that help distinguish Mascot soils from those soils of the Kingsport formation. In addition, the Mascot formation in WBW contains considerable sand matrix chert, giving rise to soils with relatively high sand content. This is especially evident in the southeast section of the watershed. Rocks of the Mascot formation are also commonly exposed above the surface, especially on steeper slopes, in contrast to other Knox Group formations in WBW. The next older formation in the Knox is the Kingsport. This formation contains chert of variable morphology, much of which is oolitic. Ledges and pinnacles commonly occur in the uppermost section of the Kingsport formation but also occur to a lesser extent elsewhere in the Kingsport only on very steep slopes. The Longview formation, stratigraphically beneath the Kingsport, typically contains dolomoldic chert in both the upper and lower sections; this characteristic is used to distinguish this formation and its approximate surficial thickness. The very high chert content in this formation made augering very difficult. Longview soils usually are mottled close to the surface. Partially because of its high chert content, the Longview formation tends to be a ridge former. However, because of the thinness of the Longview, it generally cannot be identified on a 1:12,000 scale soil map without considerable distortion but can be resolved on $1: 1200$ to 1:2400 scale high-resolution soil maps. Because of geomorphic processes of surficial soil transport, dolomoldic chert has been distributed downslope on both sides of Longview ridges.

The Chepultepec formation occurs stratigraphically below the Longview. It has a lower but variable chert content and contains some very-fine-grained sandstone strata in the lower part, which contributes to a loam rather than silt loam surface texture and a slightly lower upper subsoil clay content. There are only scattered sandstone fragments on the surface in WBW. However, sometimes the presence of loess masks the presence of higher sand content in the surface. Soils that 
formed in Chepultepec saprolitic materials have 7.5YR and 5YR hues in the upper mottle-free subsoil, while the Longview and Newala formations above and the Copper Ridge formation below typically have 2.5YR hues in the upper mottle-free subsoil.

The Copper Ridge formation is the lowest and oldest of the Knox Group. This formation also has variable chert content, but most of the chert is massive. Copper Ridge saprolitic materials are characterized by a mostly reddish clay-plugged upper zone that grades irregularly downward into a yellowish high-silt zone with red clay filling voids in old fractures. A thick lag gravel layer, thick $E$ horizons, gradational E/B and B/E horizons and red (2.5YR) upper subsoil horizons with much lower but highly variable chert content are common features of Copper Ridge soils. Figure 3 shows the approximate location and extent of each formation in WBW.

\section{GEOMORPHOLOGY}

Terminology commonly used to describe landforms and geologic materials is shown in Fig. 4. This terminology is used throughout the sections on geomorphology and the descriptions of soil mapping units that follow. Common terms used to describe a hill are summit or crest, shoulder or summit shoulder, sideslope, footslope, and toeslope. Ciests and sideslopes generally have convex shapes and are usually defined as erosion surfaces where soil particles are detached and transported to lower, generally concave, depositional environments. Sideslopes are sometimes referred to as (1) dip slopes, where the rock dip is approximately parallel to the landform slope and as (2) obsequent or scarp slopes, where the rock dips into the slope. Near-surface hydrology can differ, depending on the permeability of the underlying rock or saprolite, on these two kinds of sideslopes, with subsurface water flow being generally faster on dip slopes. Footslopes are areas where slope shapes change from convex to concave. Footslopes are either erosional or depositional, depending on the slope gradient and local convexity or concavity of the landform. Toeslopes have concave slope shapes and are depositional environments in their natural state, where, under the influence of gravity, water-saturated sediments are transported and deposited downslope as colluvium and alluvium. However, past agricultural activities tended to make even these landforms erode. Major Late Pleistocene and Holocene alluvial depositional environments in WBW are terraces, fan deltas, and floodplains that have a thin veneer of Modern-Age or post-European settlement alluvium. In these floodplain environments, sediments transported by running water are deposited as alluvium, which can be identified by its stratification. Local colluvium and alluvium also accumulated in drainage divides or saddles. 
ORNL-DWG 93-13663

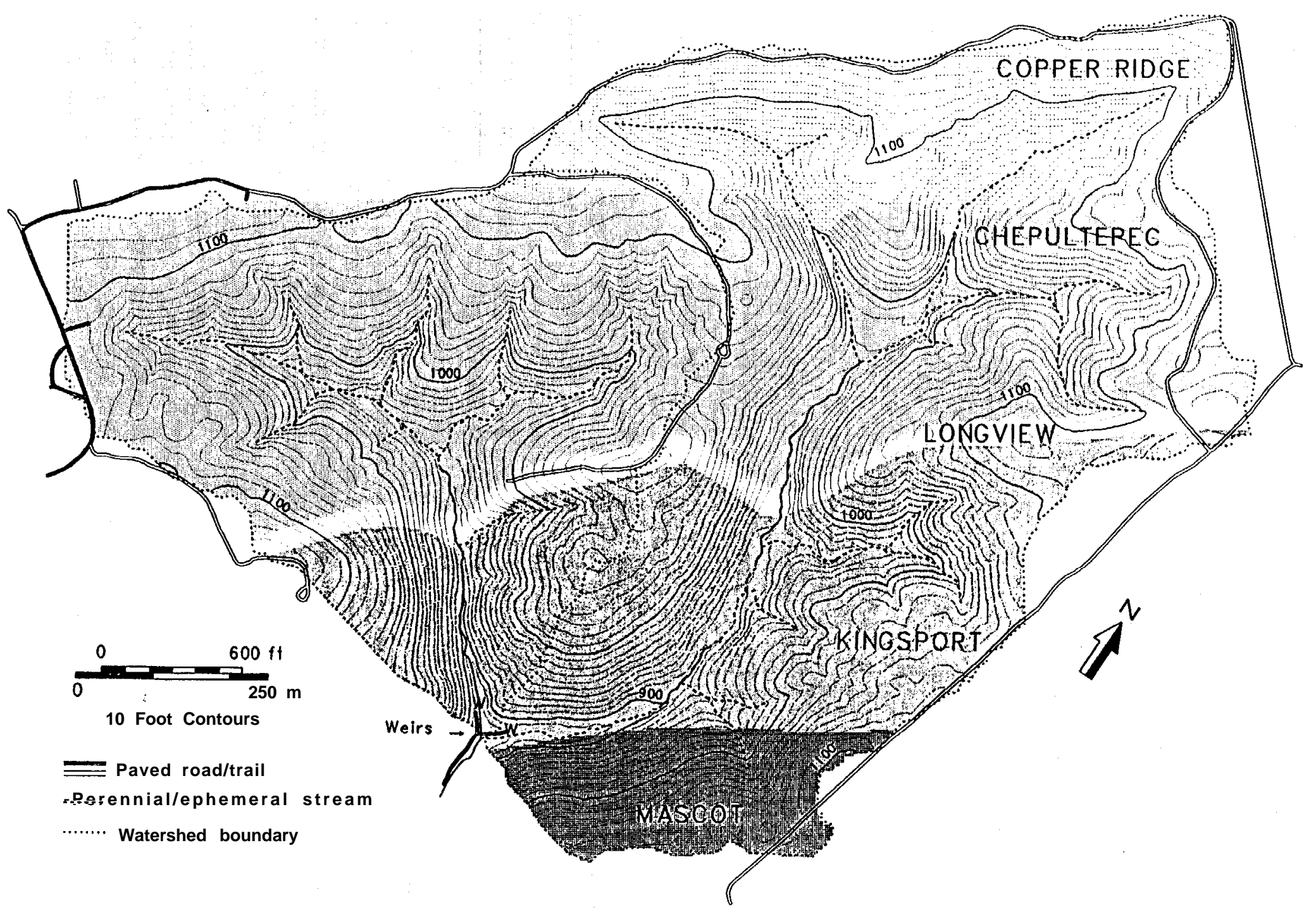

Figure 3. Geologic formations and their extent on Walker Branch Watershed 


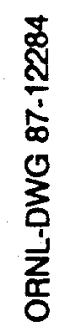

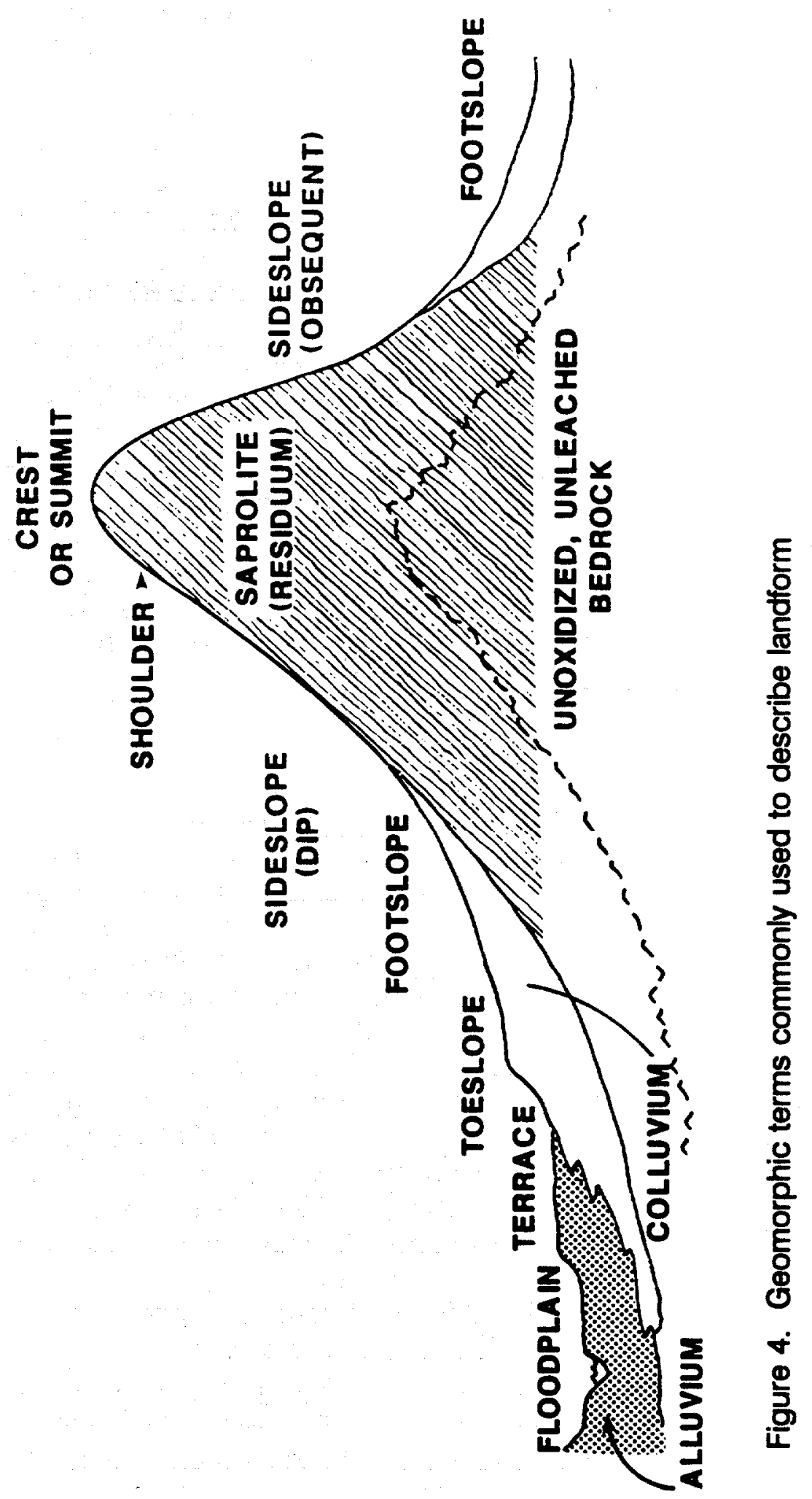


Bedrock (Fig. 4) is defined as unleached and unoxidized rock, and the weathered zones above, which have not been transported, are termed saprolite.

Saprolite is defined as isovolumetrically chemically weathered bedrock, which is a specific type of residuum. Where saprolite does not form because of a collapse of the weathered soil material, this chemically weathered earthy material is termed either regolith or residuum. The term "saprolitic materials" is commonly used to describe highly weathered carbonate rock in which there may have been partial and chaotic collapse because of insufficient framework strength of the silt and clay particles after removal of the carbonate. Some of the chaotic distribution of chert fragments in formations of the Knox Group is a result of past tectonic activities that deformed parts of the Knox Group. Evidence for this is the presence of slicken sides that were observed on large chert fragments, the brecciated appearance of some chert fragments, and the swirled appearance of saprolitic materials in some areas. The topography and depth to bedrock in the survey area is highly irregular because of the joint and fracture network and channelized flow of water at depth. Depth to rock is probably the greatest over the Copper Ridge, Chepultepec, and Longview; intermediate over the Kingsport; and least over the Mascot. Three drill holes (Fig. 5) were drilled to bedrock in March 1990. The coring logs are illustrated in Figs. 6, 7, and 8.

\section{Geomorphic History}

The geomorphic history of WBW is long and complicated. Only a postulated simplified history, based on observations starting with current or Modern Age conditions and extending back through the Holocene and Pleistocene epochs, is attempted here. The Modern Age of the Holocene epoch is defined, for purposes of this report, as beginning about 300 years ago, when the activities of European settlers resulted in large-scale deforestation, the beginning of slash-and-burn agricultural activities, and the onset of anthropogenic-accelerated erosion. The Holocene epoch covers a time span starting at the end of the Pleistocene, about 12,000 years ago and includes the Modern Age. In the Southeast, the Holocene is often been thought to have been a benign period with little climate fluctuation. However, Holocene climate changes have produced periods of geomorphic instability, the results of which are reflected in the burial of Paleo-Indian habitations on low river terraces by fresh sediments. During the Pleistocene epoch, which covers a period of at least 2 million years, several important climate fluctuations occurred in the southeastern United States that affected geomorphic stability. The widespread occurrence of colluvium in WBW is evidence for these geomorphic activities. The ancient high-elevation alluvial and ridgetop colluvial soils evidently predate the Pleistocene and are probably remnants of an earlier erosion cycle dating from the Tertiary. Topographic inversion of this magnitude requires considerable geologic time. 


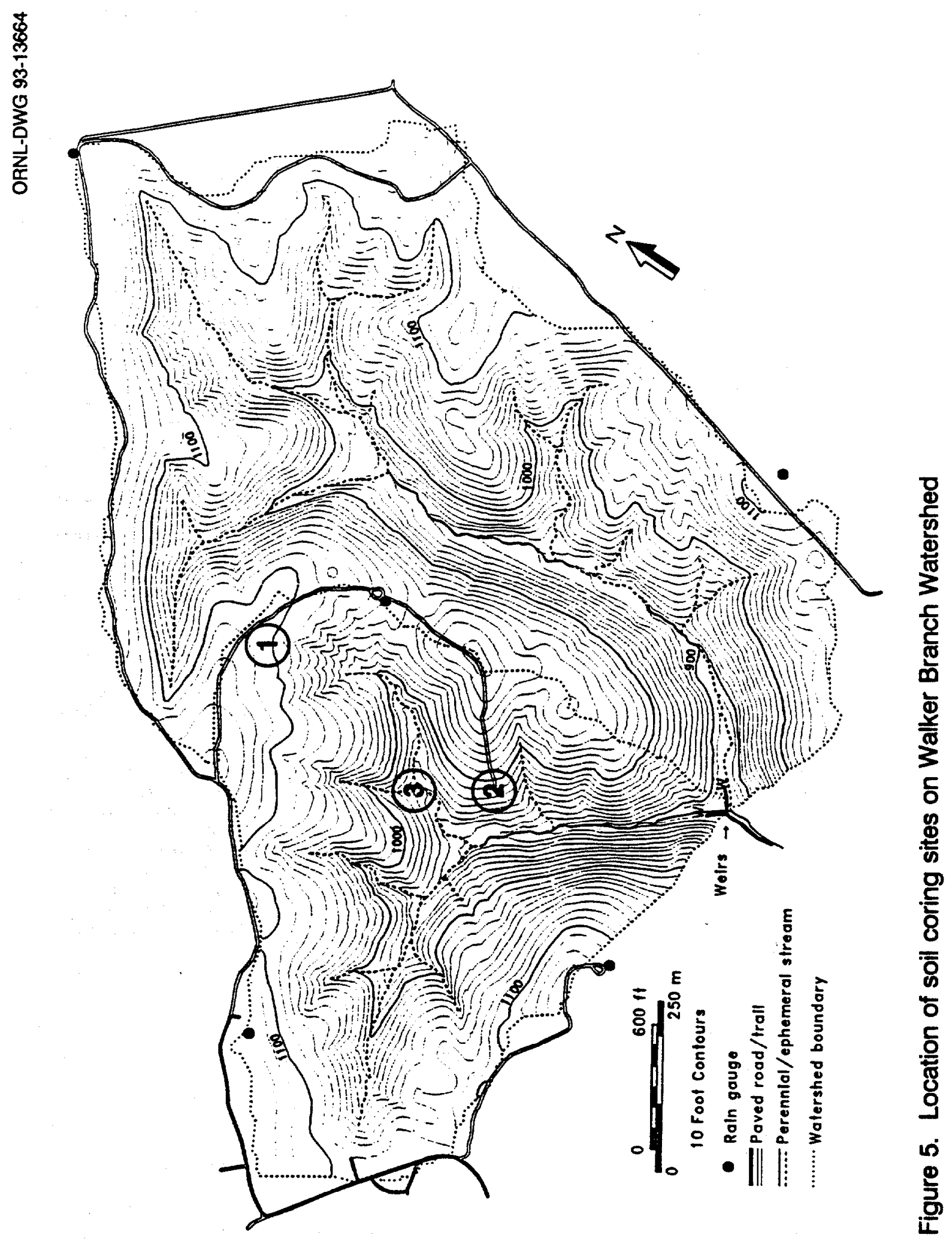


ORNL-DWG 93-13665

\section{SOIL CORE NO. 1}

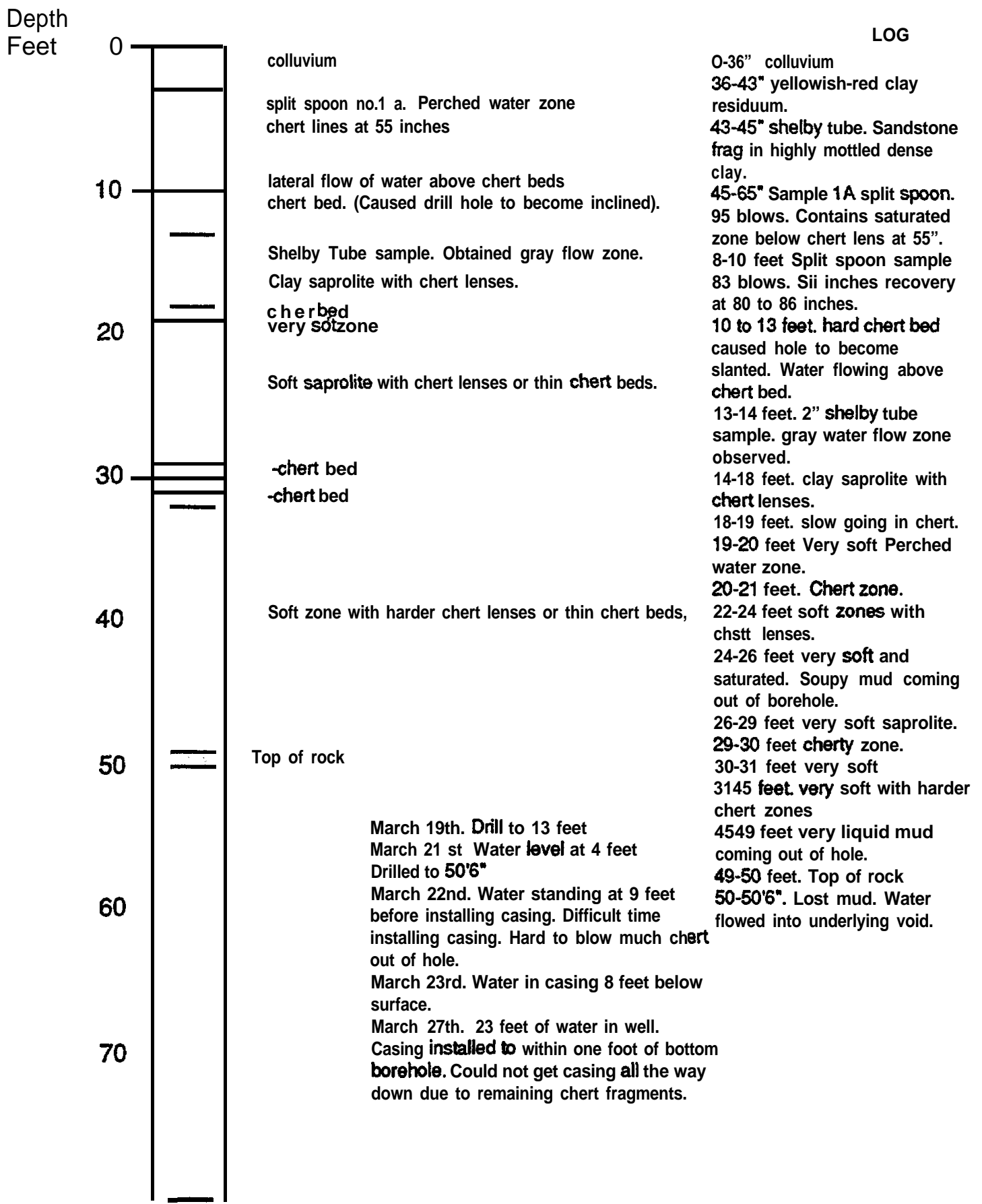

Figure 6. Soil core number 1 
Depth
Feet

\begin{tabular}{l|l}
$2.5 Y R$ & $4 / 8$ clay subsoil. \\
& Extremely cherty zone
\end{tabular}

10

Alternating zone of chert and saprolii.

Removed piece of dolomoldic chert.

Zone of much black manganese oxide resulting in brown cuttings.

-Base of Longview Formation.

Soft saprolite with very few chert zones.

Chepultepec residuum with much manganese oxide.

No chert Very soft Slow going

due to sticky sidewalls causing excessive

friction. Shelby tube showed manganese

40

oxide zones in a red to yellow saprolite

matrix.

Zones of hard and very soft saturated saprolii.

50 with some chert lenses.

\section{LOG}

0-3 feet Bt horizon of residual soil. 34.5 feet. Split spoon 80 blows. Clayey-skeletal.

4.5-5.5 feet Slow going with much chert.

5.5-7.5 feet Spl;it spoon, 80 blows. 9.5-I 1.5 feet Split spoon with 12 inches recovery.

14-16 feet Split spoon. Nearly saturated soil. Red with yellow mottling. 16-20 feet brown saprolite with much $\mathrm{Mn}$. The end of the tube was in very cherty red and yellowish saprolite. 2040 feet Soft to very firm saprolite with streaks and blebs of $\mathrm{Mn}$ oxide in a reddish and yellowish matrix.

40-55 feet. Alternating zones of very soft saprolite with occasional chert The very sticky saprolite made augering very difficult Were the Mn oxides

responsible for the stickiness?

55-74 feet Very soft saprolite with harder chert lenses.

74-75 feet Top of weathered rock. 75-75.5 feet Harder weathered rock. 75.5 feet. Auger refusal.

March 26th. Drilling.

March 27th. Finish drilling. Blew mud out of hole and installed casing to within a few inches of bottom of borehole.

-Hard zone of weathered rock

-Very hard with auger refusal about 6 inches into rock.

Figure 7. Soil core number 2 
ORNL-DWG 93-13667

\section{SOIL CORE NO. 3}

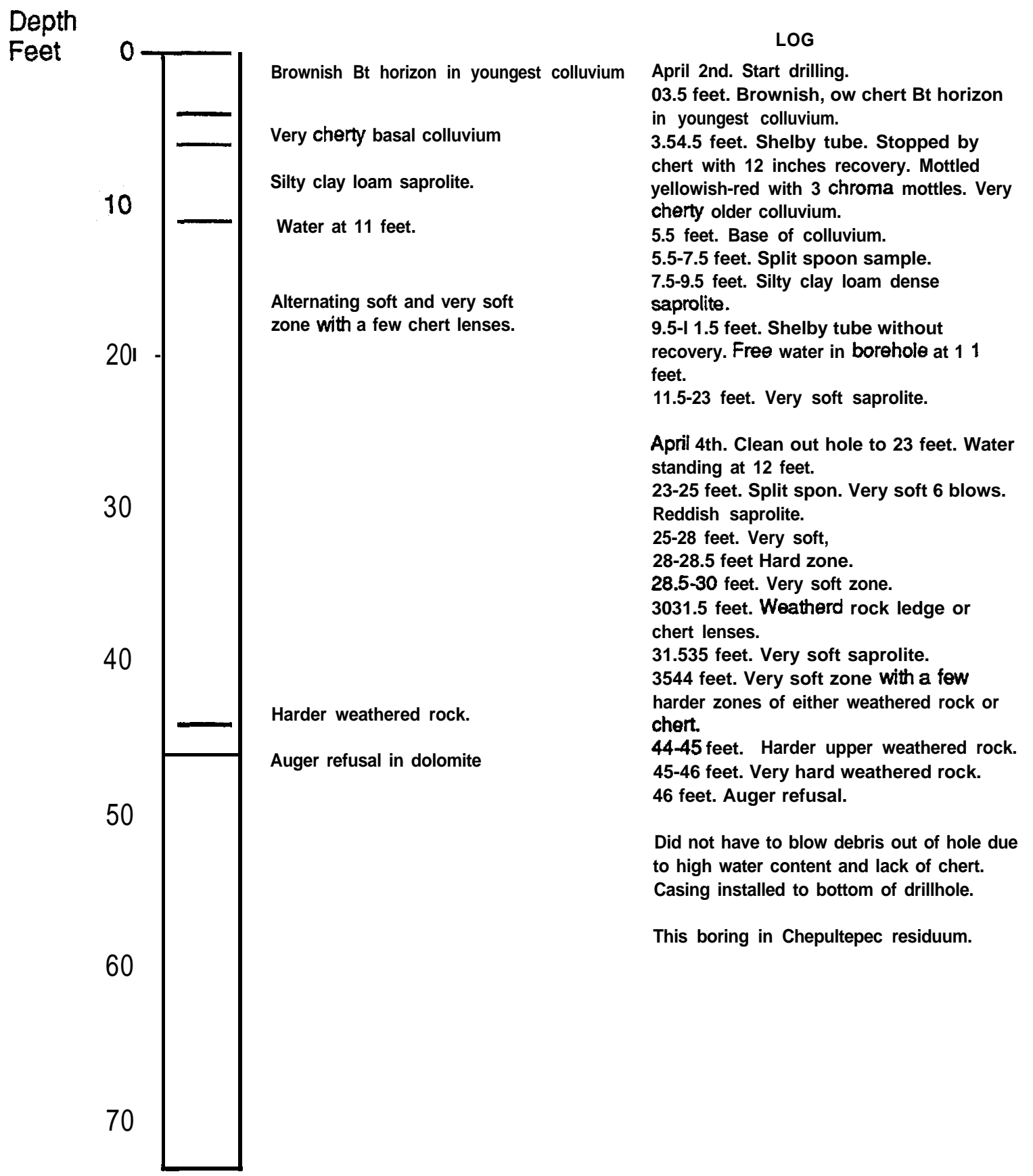

Figure 8 . Soil core number 3 


\subsubsection{Modem Age Geomorphic Processes}

The Modern Age is associated with those natural and anthropogenically accelerated geomorphic processes of hillslope erosion, sediment transport, and deposition that have been in operation for about the last 300 years. In humid environments, the dominant geomorphic processes are those of denudation (the wearing away of topographic highs) and either the filling of low areas or the transport of sediment away from the local watershed system. These processes are driven by rainfall and the force of gravity. Soil particles are detached by raindrops or overland flow and then transported downslope to a depositional site or into a stream. This natural transport process will be a slow one whenever a soil vegetative cover and a tree canopy exist above the soil surface. However, ants and other soil fauna can bring fine soil particles above the soil surface or onto or 'above the leaf litter layer. This fine material may be transported downslope and subsequently accumulate in unbreached dolines. Deforestation and primitive agricultural management practices stripped the land of vegetative cover and left bare soil exposed to the full force of raindrop impact and runoff. Agricultural fields were rapidly eroded by sheet and rill erosion and related transport processes. Erosion sediments from this activity have also accumulated in some unbreached dolines covering the high-silt-content deposits. In areas where flowing water coalesced, gullies formed and started their headwardly cutting activity into steeper landforms.

Within the WBW about half was open land, according to the 1941 U.S. Geological Survey (USGS) Topographic map of the area (Fig. 9):' However, there is evidence that some old fields had already reverted back to woods well before 1941. The open land was primarily on the more-gentle slopes and on easterly facing sideslopes that had soils with thick dark surface layers. Evidently, only the very steep slopes and extremely cherty areas in the watershed were not cultivated, but many areas were probably pastured and periodically burned. Fences were probably placed around fields to keep animals out, but cattle and pigs were allowed to roam at will throughout the woods. Most areas that were in agricultural land uses within the last 60 years can usually be readily identified by (1) the forest vegetation and (2) by the effects of plowing and erosion on soil morphology. Some areas of steeper land, once cultivated or pastured, were allowed to revert back to forest much earlier. Areas of hardwood forest without pines or cedars usually indicate a forest without much past disturbance, except for periodic logging activity. The soils in these areas show little past erosion. A hardwood forest that includes Virginia pines and cedars generally indicates that the land was once logged and cleared or partially cleared, probably pastured, or periodically burned before reverting to forest before takeover by the Atomic Energy Commission (AEC) in 1941-I 942. The soils in these areas show some effects of past erosion, but they have been revegetated long enough that the soils are regenerating their natural forest soil morphology, including a surface litter layer and thin organic 0 


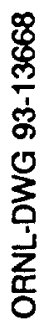

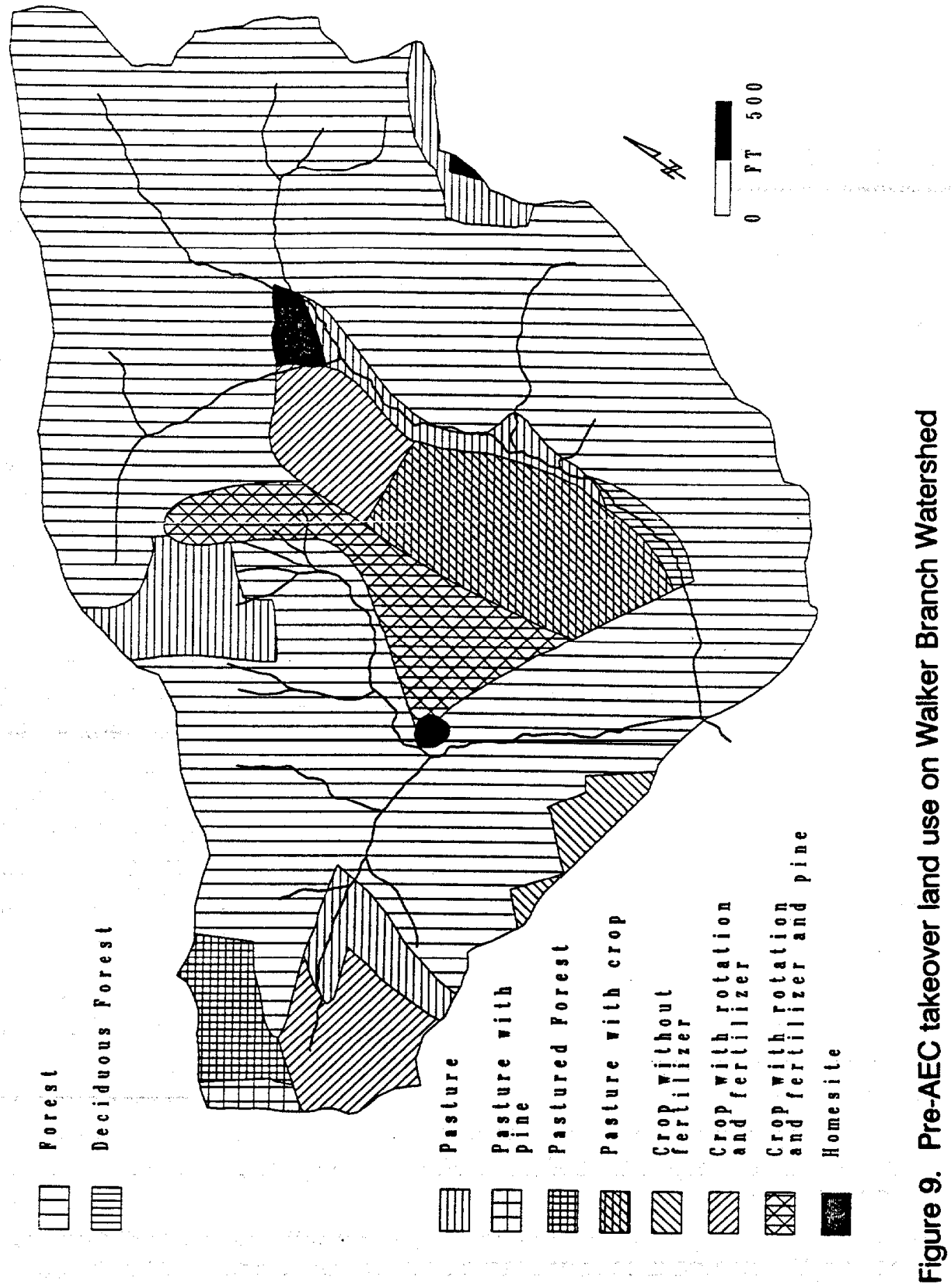


horizons. Indeed, new surface mineral A horizons 8 to $12 \mathrm{~cm}$ thick have reformed in many old fields and pastures since 1941.

Fields in the watershed that were still used for growing agricultural crops in 1941 were already or became mostly severely and very severely eroded. Erosion and crop harvests combined to remove most of the natural fertility. The abandonment of open lands after AEC took over evidently produced additional serious erosion and the formation of numerous gullies before old field succession covered the land with grass and weed vegetation and, finally, with trees. Some of these old field areas and eroded woodlands below old fields can be identified by the presence of numerous gullies that are no longer active and a forest of Virginia pine, cedars, tulip poplars, and scrub oaks, depending on remnant fertility. Past soil erosion can significantly change the hydrology of severely eroded areas. Shallow and severely eroded soils produce more overland runoff and less infiltration. Other evidence that Modern Age erosion has occurred is revealed in drainageways and floodplains, where 50 to $100 \mathrm{~cm}$ or more of Modern Age sediment (mostly topsoil derived from past agriculture and forestry land mismanagement) has covered older soils. Modern anthropogenically accelerated geomorphic processes of erosion and sedimentation have produced significant changes in some of the surficial soils of WBW.

The presence of both Modern and older multiaged colluvium on sideslopes and footslopes in the uplands indicates that past cycles of accelerated geologic erosion occurred during the Holocene and Pleistocene. Figure 10 shows the distribution of colluvium in WBW. Colluvium consists of soil particles and rock fragments that have been transported downslope under the influence of gravity, usually as a saturated mass, especially if the materials cover entire toeslopes. Other colluvium is a product of soil creep in which moist soil materials slowly move downslope. Colluvium from creep processes usually occurs on steeper slopes with less concavity and more convexity. This colluvium is generally less than $50 \mathrm{~cm}$ to about $125 \mathrm{~cm}$ thick and is termed hillside colluvium in contrast to the generally thicker colluvial deposits of footslopes. Colluvial deposits are readily identified by the lack of geologic orientation. The rock fragments in colluvium are mostly disoriented from being transported, except that larger and flatter fragments are often oriented parallel or subparallel to the slope. Colluvium derived from Knox residual soils has a distinctive appearance, with usually higher rock fragment content and other morphological clues that serve to identify it from either residuum or alluvium. The reworking and sorting of toeslope colluvium by lateral stream cutting produces a deposit that has characteristics of both colluvium and alluvium. The age of the youngest colluvium in the watershed is Modern. The largest areas of young colluvium and alluvium are identified as Modern alluvium (map symbols 981 and 982). This soil material, in which genetic soil horizons have not yet formed, covers older soils and occurs as fans at the outlets of gullies and drainageways and at the base of cultivated slopes throughout the area. 


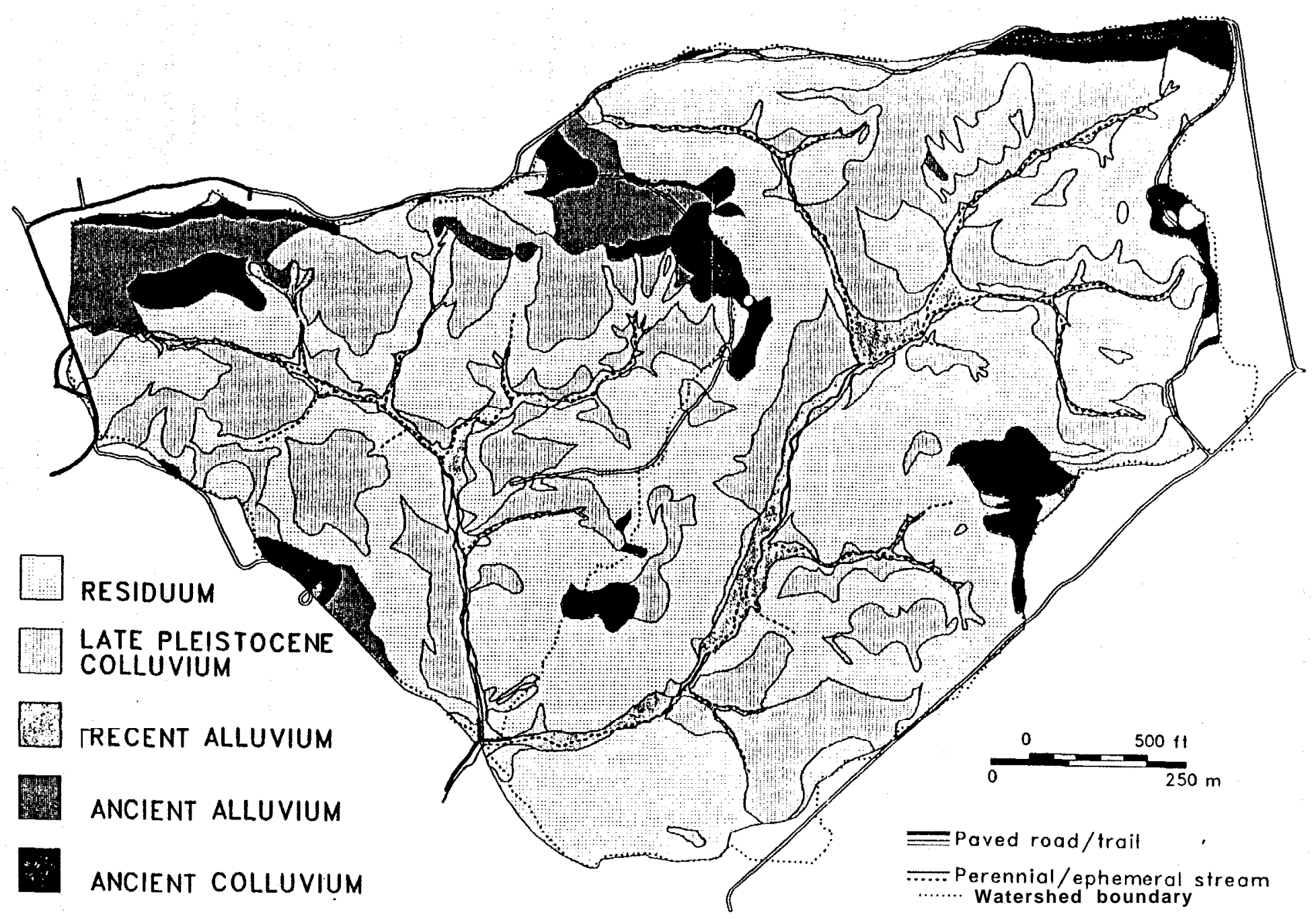

Figure 10. Distribution of Pleistocene colluvium on Walker Branch Watershed 


\subsection{Holocene Geomorphic Processes}

The next significant alteration of soils and landforms took place between approximately 4000 and 2800 years ago, a period of time in the Holocene defined in this report as the Neo-glacial. Holocene-aged Neo-glacial colluvium and alluvium have not been positively identified in WBW, probably because the relatively permeable soils were not excessively destabilized by the wetter and colder conditions during this period. However, Holocene-age colluvium occurs elsewhere on the ORR on the Rome and Conasauga formations and on some formations of the Chickamauga (1) in doubly concave landform segments that occupy footslope and toeslope positions at the base of slopes, (2) as fans at the outlets of headward-eroding drainageways, (3) on sideslopes in doubly concave elongated landform segments, and (4) in saddles between subwatersheds. Many colluvial landforms were intensively used for agricultural activities and were severely to extremely eroded with few to many shallow to deep gullies. Holocene colluvium can overlie (1) in-place saprolite, (2) the remnants of a truncated older colluvial soil of early Holocene or Pleistocene age, or (3) the truncated remnants of residual soils.

\subsection{Pleistocene Geomorphic Processes}

The largest acreage of colluvium exposed at the surface of WBW is of late Pleistocene age (Fig. 10). Because erosional geomorphic processes were dominant on many surrounding landforms, the extent of older early Holocene and late Pleistocene colluvium (and its associated older upland residual soils) is sporadic except on the Knox Group. Otherwise, no attempt was made to identify and separate young from older Pleistocene colluvium in the watershed, primarily because of the difficulty of exposing the soil stratigraphy. Knox colluvium can be identified by (1) its lower subsoil clay content, (2) the subsoil color, which is at least one hue less red than the adjacent residual soils, and (3) the lack of a distinct genetic $\mathrm{E}$ horizon. Chert content of Knox colluvial soils is variable, ranging from about $15 \%$ to more than $35 \%$. Colluvium was mapped on the Knox Group whenever it was more than $50 \mathrm{~cm}$ thick, a depth where it can be easiiy recognized and where it seems to have an effect on near-surface hydrology. More colluvium occurs on south- and west-facing slopes than on north- and east-facing slopes. Because of the more favorable physical properties of colluvium compared with residual soils, even though it usually has a higher chert content, colluvium was sought after and intensively cultivated. Often, in mapping Knox colluvium, the presence of certain tree species, characteristic of old field succession on Chestnut Ridge, was a key indicator of its presence and extent.

The climate shifts of the Pleistocene produced significant changes not only in the types of geomorphic processes that were active in the area, but in the rates and intensity of these processes. Most upland soils in the watershed underwent 
several cycles of denudation during the Pleistocene epoch, generally corresponding to periods of maximum glaciation. Some areas of more geomorphically sensitive soils, especially those on steeper slopes, were periodically stripped down to hard rock or to hard saprolite, whereas other less sensitive areas were hardly affected. Some geomorphically sensitive soils are those high in sift and clay that become easily saturated with water, whereas nonsensitive soils are more permeable and do not easily become saturated. Soils on steeper slopes are also more geomorphically sensitive than soils on flatter slopes. The latest major episode of denudation occurred during the Wisconsinan, a time period of several thousand years that ended about 12,000 years ago. The longest period of unstable soil conditions occurred between 18,000 and 25,000 years ago when Wisconsinan glaciers extended to their maximum. Numerous freeze-thaw cycles, along with periods of deep winter freezing and downward melting of the surface in the spring, produced saturated conditions that destabilized many upland soils. Large volumes of soil flowed downslope as mud and debris flows, filling in topographic lows and choking stream valleys and river channels. Figure 10 shows the rather large extent of Pleistocene colluvium in WBW. Scattered remnants of older alluvium from still earlier events in the Pleistocene are preserved in stable permeable landforms at higher elevations in WBW and elsewhere on Chestnut Ridge.

Dust blowing around during phases of the Pleistocene has apparently accumulated in certain locations on Chestnut Ridge. Here, in shallow depressions, loess or silty low-chert-content hillslope sediments accumulated, burying the very cherty lag gravel surfaces of colluvial soils. The chert-free or nearly chert-free loess or silty sediment has, in turn, often been buried by younger Holocene- or Modern-Age silty slope wash that contains a moderate content of chert fragments. In one wet depression on Chestnut Ridge close to the northern WBW boundary, at least two episodes of loess deposition seem to have been preserved. Other areas where loess has been preserved occur in WBW where yellow-brown silty deposits overlay ancient alluvium.

At the cessation of Wisconsinan glaciation, climate moderation produced' upland soil stability, allowing streams to down-cut, channelize, form meanders, and to gradually remove accumulated sediments and for drainageways to renew their headward cutting and widening activities.

\section{Early Pleistocene and Late Tertiary Geomorphic Processes}

The geomorphic events and processes that took place during the Wisconsinan were simply repetitions of similar events that took place during the lllinoian and Nebraskan glacial periods of mid and early Pleistocene. Remnants of old terraces from these earlier, more extensive Pleistocene events are preserved mostly on the Chestnut Ridge and WBW in areas underlain by permeable Knox soils. Permeable 
substrates and surface armouring by coarse fragments are two important requirements'for the preservation of paleosols and also for topographic inversion. Figure 11 illustrates the general process of topographic inversion, and Fig. 12 shows a hypothesized topographic inversion on Chestnut Ridge. The areas of ancient alluvium and toeslope colluvium must represent ancient landforms that were at the low places in an older landscape. There are four elevations on Chestnut Ridge where ancient alluvial and colluvial soils, either buried, exhumed, or never buried, have been preserved. At elevations of 1050 to $1060 \mathrm{ft}$ and extending to about $1100 \mathrm{ft}$ in places on Chestnut Ridge, ancient toeslope colluvial and alluvial soils have been preserved on northeast and east aspects, and ancient footslope-toeslope colluvium' has been preserved on what are now broad ridgetops. Also on Chestnut Ridge, old Pleistocene alluvial soils occur at elevations of 875 to $900 \mathrm{ft}$. The age of deposition of most of the ancient colluvial and alluvial soils is assumed to be late Tertiary to early Pleistocene. The extent of both ancient alluvium and ancient colluvium (colluvium without a present-day source) in WBW is shown in Fig. 13. The No. 991 soils are interpreted to be ancient local alluvium in that the alluvial materials contain chert fragments and abundant mag-hemite nodules. Of interest is the presence of a young surficial silty covering that has a yellowish brown or strong brown subsoil and a relatively high content of soil vermiculite (personal communication to D. A. Lietzke, 1990, from $P$. Jardine, ORNL, ESD). Soil vermiculite, being highly reactively, tends to indicate a relatively young deposit. Only one small area of main-channel ancient alluvium, identified by its dark red color, high clay content, and lack of chert fragments, was mapped in the watershed (map symbol No. 990). The very cherty remains of a doline having undergone topographic inversion have also been preserved in the watershed, providing additional evidence for topographic inversion. Only small areas of residual soils in the watershed (Fig. 14) were above the elevation of the ancient alluvium and colluvium, ranging from about $1140 \mathrm{ft}$ at the east end of the watershed to about $1120 \mathrm{ft}$ at the west side. The elevation of residuum that still occurs above this ancient alluvium drops to about $1080 \mathrm{ft}$ on the West Chestnut Ridge part of the Reservation, a potential indication of the river gradient during the late Tertiary erosion cycle. Further indication that there were higher topographic areas in the vicinity when this ancient alluvium and colluvium was deposited is the lack of Knox chert to the north on the Conasauga and to the south on the Chickamauga. Pleistocene erosion processes lowered both the Conasauga and the Chickamauga relative to the Knox. Only Knox chert derived from mid- and late-Pleistocene headward cutting of drainageways into Chestnut Ridge, occurs in drainageways and fan terraces underlain by the Conasauga and Chickamauga. 


\section{TOPOGRAPHIC INVERSION}
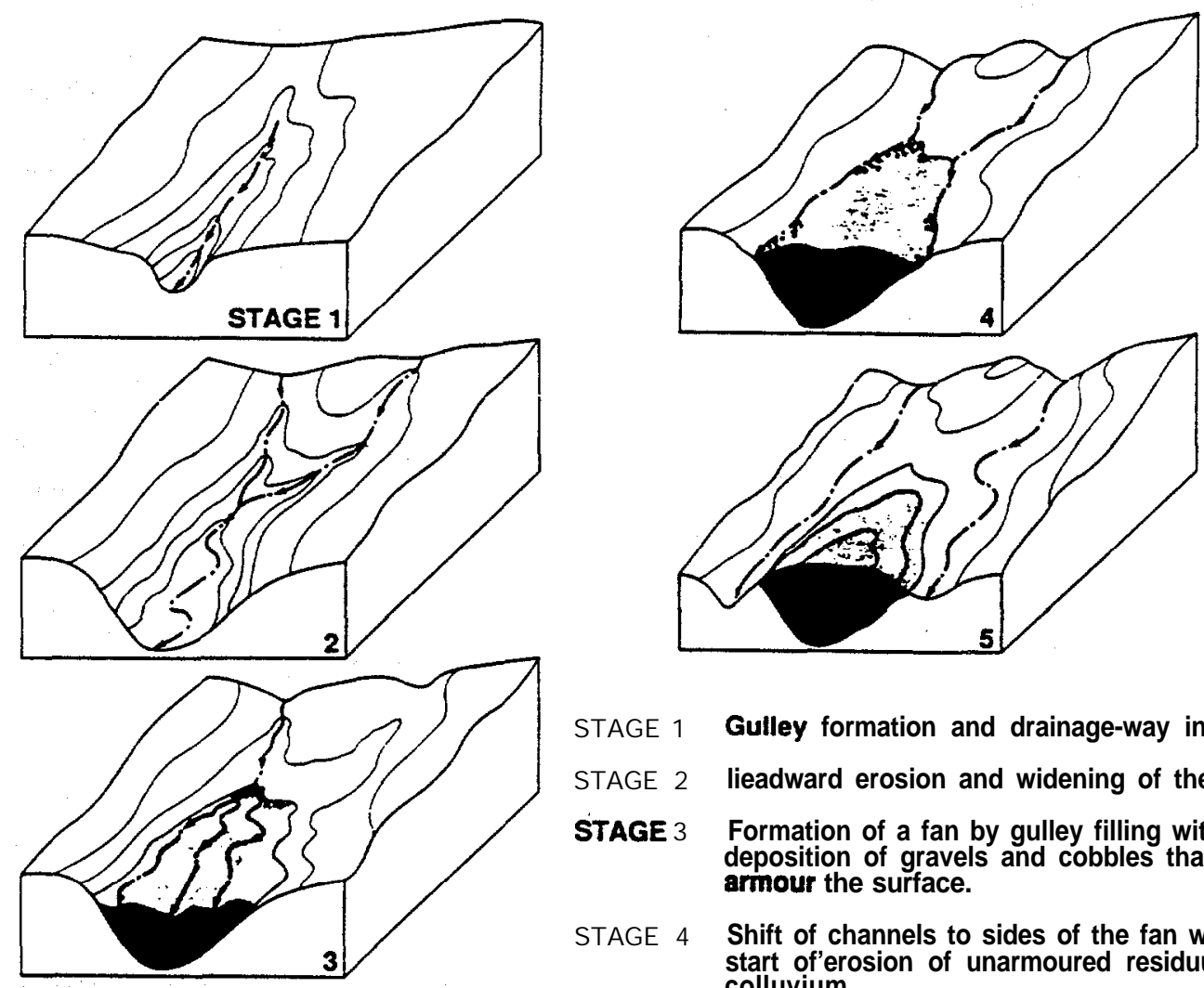

STAGE 1 Gulley formation and drainage-way intrusion

STAGE 2 lieadward erosion and widening of the gulley

STAGE 3 Formation of a fan by gulley filling with deposition of gravels and cobbles that armour the surface.

STAGE 4 Shift of channels to sides of the fan with the start of'erosion of unarmoured residuum and colluvium.

STAGE 5 Formation of a-topographic inversion where drainage-way fan becomes a topographic high as two younger drainage-ways continue downward cutting on either side of the fan.

Figure 11. Topographic inversion 


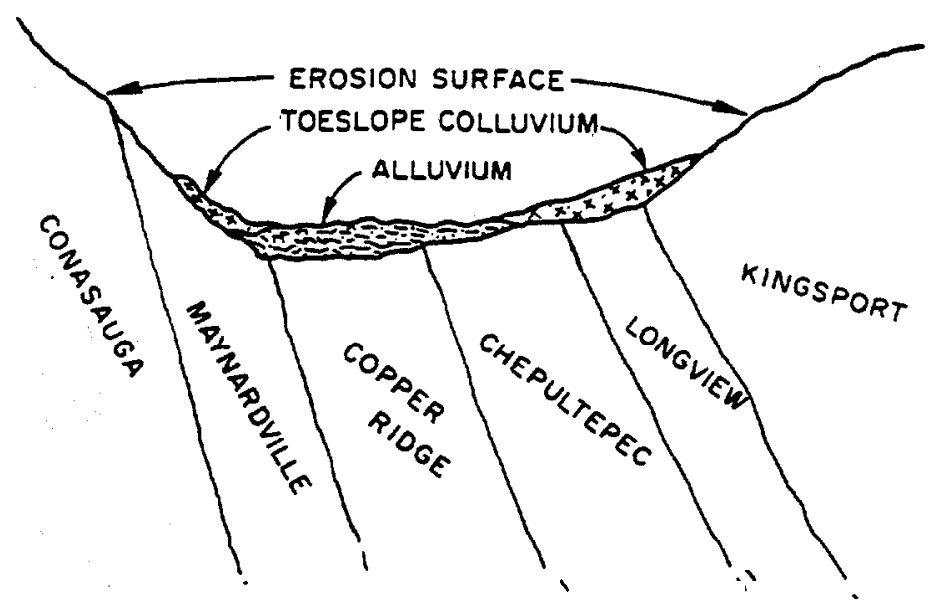

LATE TERTIARY SURFACE?

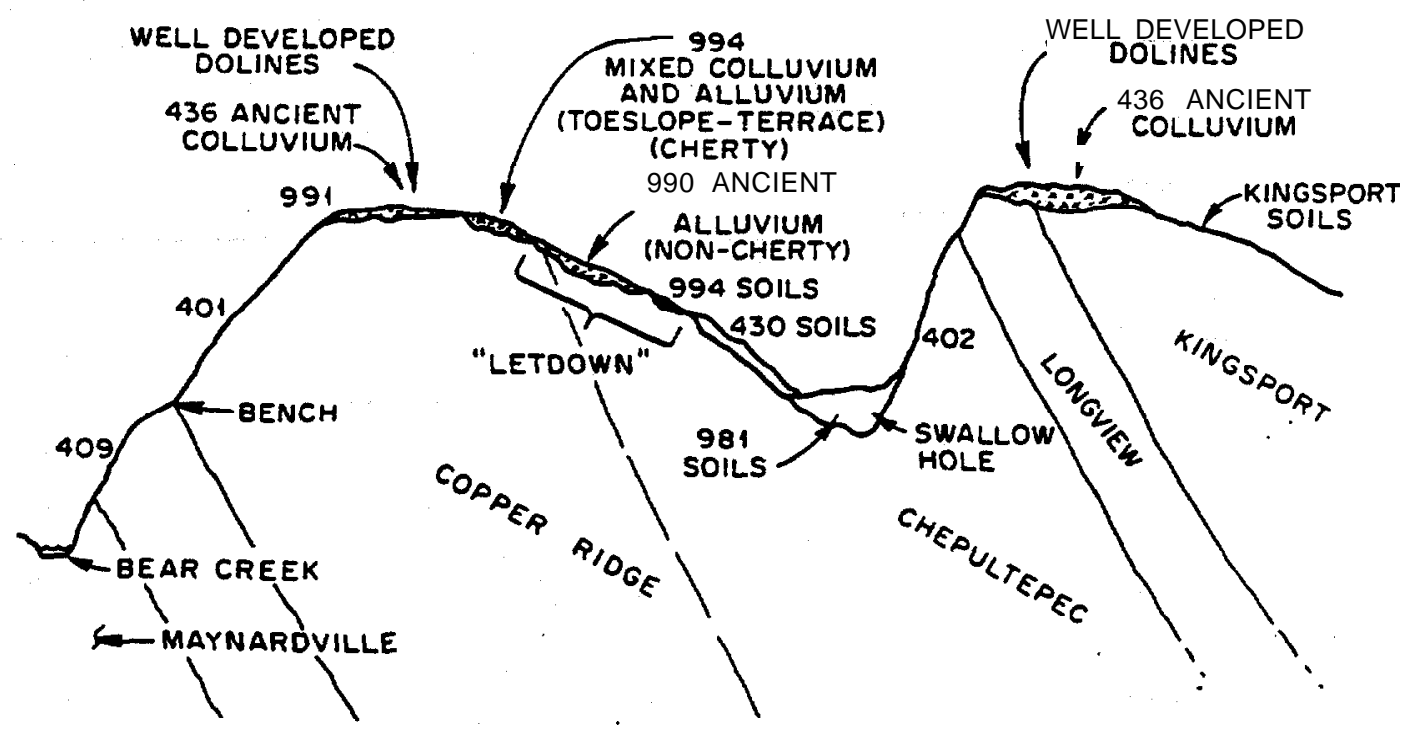

Figure 12. Topographic inversion on Chestnut Ridge 
ORNL-DWG 93-13670

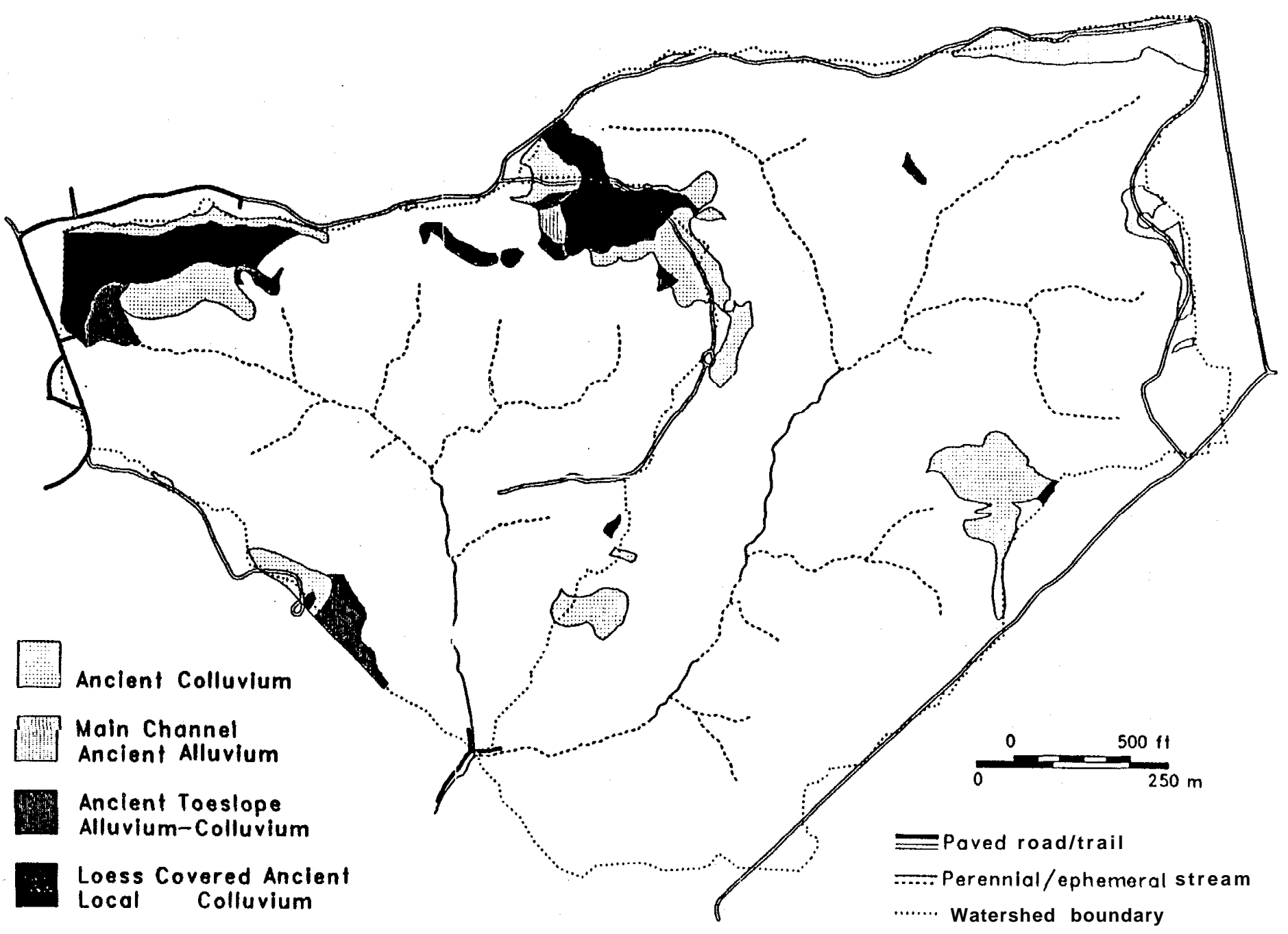

Figure 13. Location of ancient alluvium and ancient colluvium on Walker Branch Watershed 


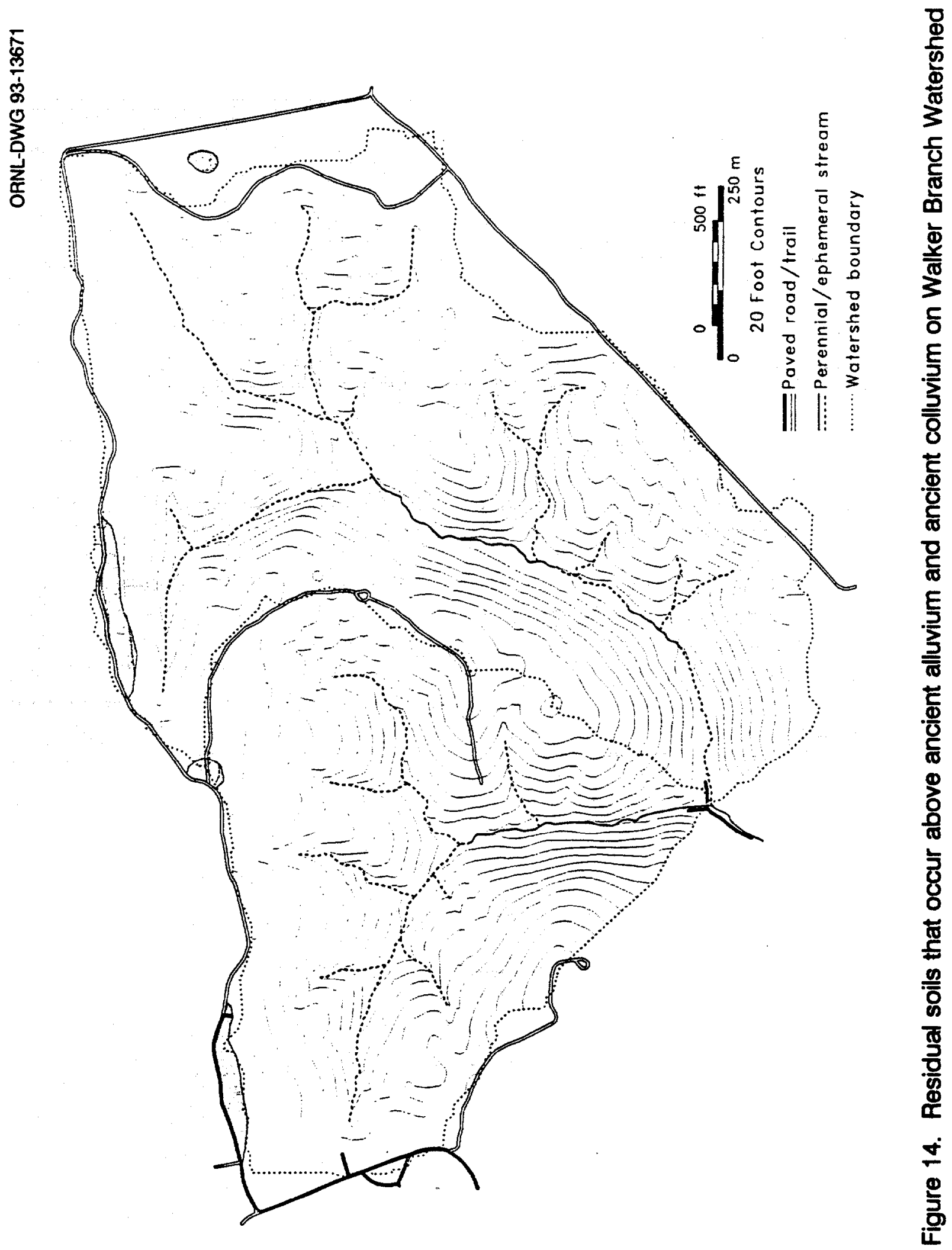




\section{KARST GEOMORPHOLOGY}

Karst geomorphic processes in WBW are dominated by the infiltration of rainfall and its generally downward movement. Overland runoff in this forested watershed tends to be a rare event and usually occurs only during catastrophic rainstorms. Water moving down through the soil becomes acidified and, as it moves into the rock beneath, dissolves calcium carbonate. Chemical weathering processes transform the rock into saprolite if there is enough structural integrity; otherwise the siliceous residue collapses. Water percolating down through soil moves in defined pathways, and when it reaches rock is further confined to cracks and joints. Water flowing, through rock enlarges cracks into solution channels and eventually into larger caves. Only one cave opening has been observed within the watershed. The soil mantle may bridge these voids for a time, but eventually the soil collapses into the underlying void forming a distinctive surface feature often called a sinkhole; the term "doline" is used in this report. A doline is a collapse structure without an open swallow hole. Some dolines also form when a cave roof collapses, whereas others form gradually as a solution pipe is enlarged and soil gradually sloughs into the opening. Only a very few dolines observed on Chestnut Ridge have extensive rock outcrops on their steep sideslopes. Most doline sidewalls are mantled with a layer of colluvium, with variable thickness. Figure 15 shows the location of all dolines, breached or unbreached, in WBW. Particle size data from an unbreached doline located in the East Chestnut Ridge waste disposal site is shown in Fig. 16, illustrating the considerable variability in particle size distribution. Horizontal lines on the left side of the figure indicate observable discontinuities. Samples were collected from the sidewall representing varying thickness that were identified visually. 
ORNL-DWG 93-13672

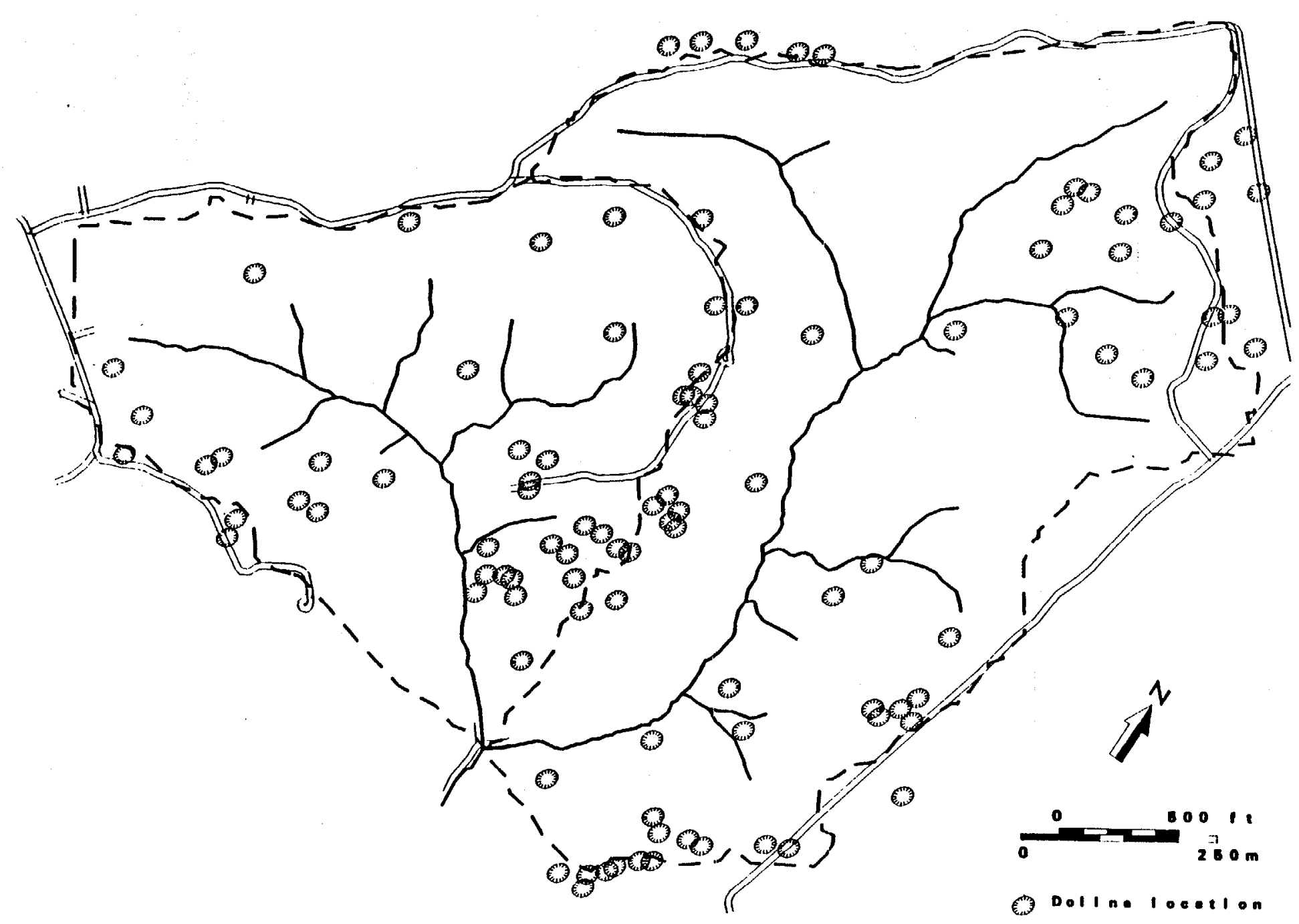

Figure 15. Location of dolines on Walker Branch Watershed 
ORNL-DWG 93-13673

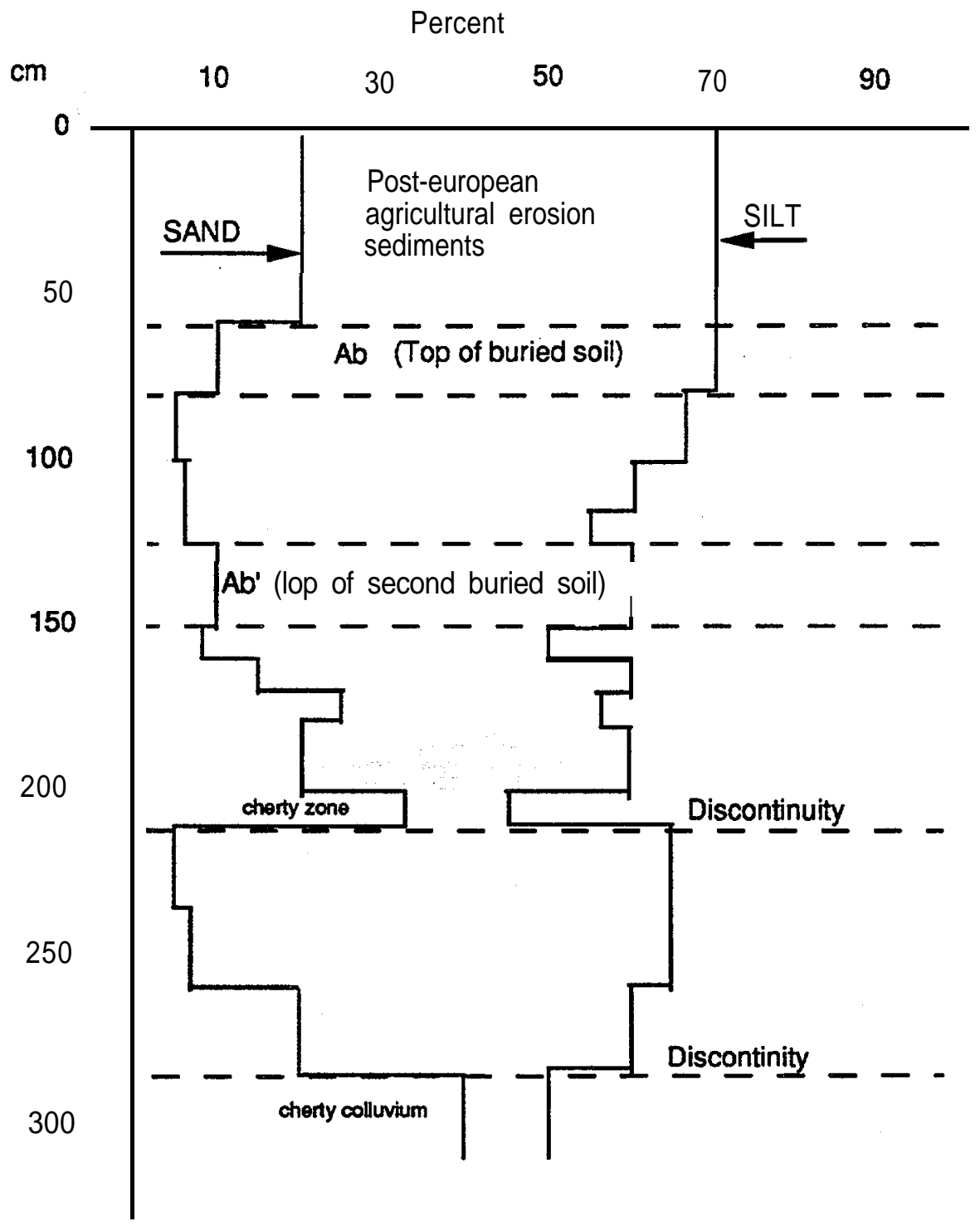

Figure 16. Silt and Sand Stratigraphy in East Chestnut Ridge Doline C. Data by Stan Crownover, University of Florida 


\section{TECHNICAL APPROACH TO SOIL MAPPING}

Based on previous geologic and soil mapping in the watershed, the approximate locations of the geologic formations were known. Also, based on past mapping elsewhere on Chestnut Ridge, many morphologic characteristics of residual, colluvial, and ancient alluvial soils were also known. A basic premise in this soil mapping project was that residual soils and landforms were closely associated (Arnold 1993, Huggett 1975). Geomorphic erosional processes that shaped landforms to their current state have also affected the soil system and the basic soil-forming processes of (1) additions to the system, (2) losses from the system, (3) translocations within the system, and (4) transformations within the system (Jenny 1941, Simonson 1959, Smeck et al. 1983).

Traverses across landforms were made at closely spaced but irregular intervals, the spacing depending on the suspected or observed spatial variability. Observations of genetic soil horizons were made with a $7-\mathrm{cm}$-diam auger. Numerous previously dug pits were also utilized. Some new pits were dug to expose soil horizons in those additional soils that were recognized and mapped. Soil horizons, horizon sequences and thicknesses, colors, soil textures, and other morphologic features were utilized in recognizing distinctive soils. Factual data were organized into conceptual taxonomic entities termed "soil series" in which each soil series was identified by the first three digits of the five-digit symbol shown within each delineation on the soils map. Each residual soil series mapped in the watershed is confined to a particular geologic formation, particular landforms, or parent materials and has a certain sequence of genetic soil horizons, which has a certain narrowly defined range in colors, textures, and other morphological features. Soil series are represented on the ground by specific bodies of soil, termed "pedons." A pedon represents a volume of natural or disturbed soil that possesses all of the morphologic properties utilized in defining the taxonomic concept of a soil series.

In the process of mapping, individual soils or polypedons belonging to one soil series are found to have a certain extent on the landform. A line drawn around this soil body becomes a mapping delineation, indicating that the soils within the delineation are more alike than the soils outside the delineation. Slope gradient, slope shape, and past erosion phases of a soil series are used in conceptually defining a map unit. A map unit, then, is a taxonomic concept that relates a particular soil series to particular segments of a landform. The sum total of all the delineations that are identified by a particular soil series identification, particular slope, and erosion phase comprises the physical "on the ground" representation of a particular map unit concept. Each mapping delineation, identified by five symbols, is different in some respects from all other delineations of the map unit. 
However, if the soil mapping is accurate, each delineation of a map unit should have similar interpretations. Figure 17 is a generalized surficial geology-soils map of Walker Branch Watershed. A large scale 1:2400 soil map (Fig. 18) is included in a pocket at the back of this report. 







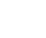




\section{WALKER BRANCH WATERSHED SOIL CODING LEGEND}

A five digit number codes all important soil map information for easy computer sorting and manipulation of the Walker Banch Soil Survey. The first digit codes for geologic formations. The second digit codes for geomorphic information including residuum, colluvium, and alluvium by major geologic formations and Pleistocene to Modern alluvium. The third digit codes for each individual soil. The fourth digit codes for slope gradient class. The fifth digit codes for soil erosion class or other soil or landform properties considered important for planning or utilization. Bold print indicates which parts of the code are used in WBW.

\section{1st-digit Codes - Geologic formations}

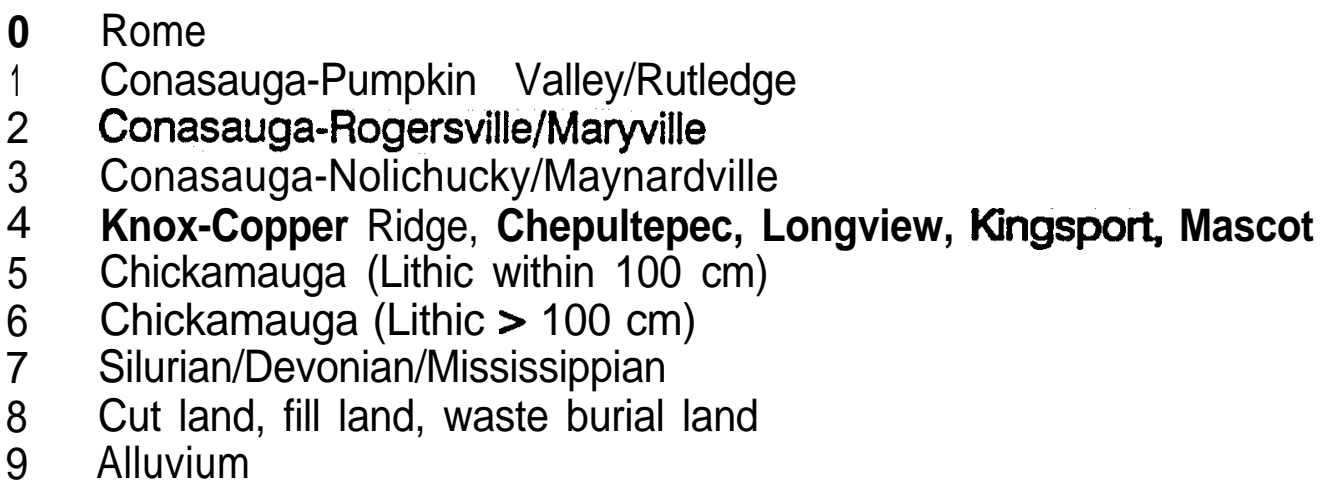

\section{2nd-digit Codes - Geomorphic codes}

$\begin{array}{ll}\mathbf{0} & \text { Residuum } \\ 1 & \text { Rome colluvium } \\ 2 & \text { Conasauga colluvium } \\ 3 & \text { Knox colluvium } \\ 4 & \text { Chickamauga colluvium } \\ 5 & \text { Silurian/Devonian, Mississippian colluvium } \\ 6 & \text { Rome alluvium } \\ 7 & \text { Conasauga alluvium } \\ \mathbf{8} & \text { Knox/Chickamaugaalluvium } \\ \mathbf{9} & \text { Pleistocenealluvium }\end{array}$

3rd-digit Codes - Individual soil identification numbers 0 through $\mathbf{9}$ (Soil series is explained in more detail in Sect. 4.1.) 
4th-digit Codes - Slope classes

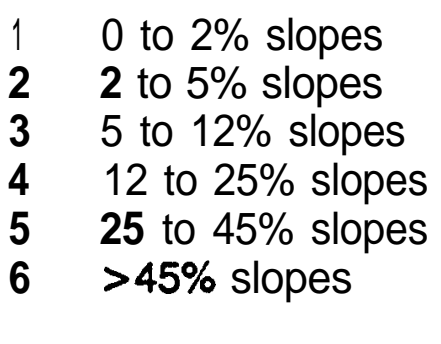

\section{5th-digit Codes - Erosion classes from past land use and other codes for disturbed lands}

1 none to slightly accelerated erosion

2 moderately accelerated erosion

3 severely accelerated erosion

4 very severely erosion with common to many gullies

5 Not assigned in WBW

6 Not assigned in WBW

7 Not assigned in WBW

8 Not assigned in WBW

\section{EXAMPLE OF SOIL MAP CODE}

40043 4---- is the geologic formation code

$-0--$ is the geomorphic code

400 - is the soil series code

-.-4- is the slope code

---3 is the erosion code

\subsection{SOIL IDENTIFICATION LEGEND}

The soil series in this section are organized with respect to geologic and geomorphic criteria. Each soil series is identified by a three-digit number, which consists of the first three digits of the five-digit mapping unit number. Most soil series identified in the WBW do not have an analog name. However, some soil series identified in WBW are very similar to named Soil Conservation Service soil series; these designations have been included in parenthesis. 


\section{KNOX GROUP}

\section{Copper Ridge Residuum}

400 Typic Paleudults; clayey, kaolinitic, thermic. (Cherty and noncherty Fullerton with degraded upper Bt.)

401 Typic or Humic Paleudults; clayey, kaolinitic, thermic. (Occurs only on east and north aspects and has thicker and darker surface layer.)

\section{Chepultepec Residuum}

402 Typic Paleudults; clayey, kaolinitic, thermic. (Dunmore, cherty and noncherty with 7.5YR or 5YR upper Bt horizon.)

408 Typic Paleudults; loamy-skeletal, siliceous, thermic. (Bodine-like series. Chert beds.)

\section{Lonaview Residuum}

403 Typic Paleudults; clayey or clayey-skeletal, kaolinitic, thermic. (Clayey-skeletal Fullerton Variant with 2.5YR upper Bt and highly mottles lower subsoil.)

\section{Kinasoort Residuum}

406 Typic Paleudults; clayey, kaolinitic, thermic. (Fullerton)

407 Hapludults-Hapludalfs-Rock Outcrop Complex; clayey, mixed, thermic.

\section{Mascot Residuum}

404 Typic Hapludults; clayey, mixed, thermic. (Fullerton)

405 Hapludalfs-Hapludults-rock outcrop complex; fine, mixed, thermic.

\section{Knox Group Colluvium}

430 Fragic Paleudults; fine-loamy or loamy-skeletal, siliceous, thermic. (Shack and Tassos series.)

431 Fluventic Dystrochrepts; fine-loamy, siliceous, thermic. (Modem slope wash from old agricultural fields and bottoms of some dolines. Greendale series.)

433 Typic Paleudults (humic); fine-loamy or loamy skeletal, siliceous, thermic. (Toeslope colluvium from $A$ and $E$ horizons of upslope soils, without a red argillic horizon. Has a brown argillic horizon.) (Pace series)

434 Typic Paleudults; fine-loamy. siliceous, thermic. (Minvale series) 


\section{ANCIENT COLLUVIUM}

436 Typic Paleudults; loamy-skeletal, siliceous, thermic.

\section{Doline Sediments}

437 Typic or Glossic Fragiudults; fine-silty/loamy-skeletal, siliceous, thermic. (Loess over old colluvium on uplands or in depressions.) (Tarklin-like.)

438 Typic and Aquic Hapludults; fine-silty; siliceous, thermic. (Silt capping over colluvium in depressions.)

439 Typic and Aeric Ochraquults; fine-silty, siliceous, thermic. (Silt capping over cherty colluvium in depressions.)

\section{ANCIENT ALLUVIUM}

990 Rhodic Paleudults; clayey, oxidic, thermic. (Decatur Soil Series.)

991 Typic Paleudults; fine-silty, siliceous, thermic (Loess over ancient local alluvium over Knox residuum. Has profile with at least two argillic horizons.)

994 Typic Paleudults; fine-loamy, siliceous, thermic. (Ancient alluvium mixed with chert. Mapped over Knox Dolostones.) (Waynesboro-like without loess capping.)

HOLOCENE ALLUVIUM

999 Typic Hapludults; fine-loamy, siliceous, thermic. (Sequatchie-Variant.)

\section{MODERN ALLUVIUM}

$\underline{\text { Knox Oriain }}$

980 Udifluvents-Hapludults-Fragiudults complex; fine-loamy/loamy-skeletal, siliceous, thermic, acid.

981 Typic and Aquic Udifluvents; loamy-skeletal, siliceous, thermic.

982 Typic and Aeric Fluvaquents; loamy-skeletal, siliceous, thermic. 


\subsection{DESCRIPTIONS OF KNOX GROUP SOILS AND LANDFORMS}

Soils that formed in Knox Group residuum and are on slopes up to 25\% seem to have thick enough, clay-enriched, subsoil Bt argillic horizons and solum thicknesses to classify as Paleudults. Knox Group residual soils on slopes exceeding $25 \%$ are mostly Hapludults, based on observations in trenches, even though laboratory data does not show much decrease in clay content, a consequence of clay translocation into porous saprolite. The presence of saprolite-yellow colors (a different shade'of yellow than drainage yellow mottles) and loss of most pedogenic soil structure within a depth of $1.5 \mathrm{~m}$ would indicate that the argillic horizon terminates'before the depth required for Paleudults, even though transitional $\mathrm{BC}$ and $\mathrm{CB}$ horizons beneath 'may be quite thick and 'extend for many centimeters deeper. The WBW area encompasses all formations of the Knox Group. The Longview formation, situated -between the Chepultepec and Kingsport formations, is not very 'thick; but it contributes large blocks of chert in some areas that mantle the surface. In addition, numerous quantities of smaller-sized Longview chert have been. let down as "lag" "onto the uppermost Chepultepec and lowermost Kingsport. Often, the Longview can be identified by chert ledges, which are most often exposed. on the east side of drainageways. Some of the chert from the Longview also has a distinctive appearance-the presence of dolomolds. Dolomolds are cavities in the chert that were once occupied by calcite or dolomite rhombs. In the current geomorphic erosion cycle, the Longview formation occupies ridgetop positions. However, where, ridgetops in WBW underlain by the Copper Ridge, Chepultepec, and Longview are broad enough, the surface is'often mantled with a thin layer of ancient colluvium. This indicates that in a previous erosion cycle, what are now ridgetops were situated in toeslope-drainageway landforms similar to the present-day toeslope landforms, where very cherty colluvium is now accumulating. Topographic inversion occurred because the very high chert content of both the residuum and overlying colluvium preserved the soils beneath, while the adjoining less-cherty residual soils, lacking any armouring, underwent faster rates of denudation..

A combination of morphologic' features were utilized in the identification of soils that formed in the Copper Ridge, Chepultepec, Kingsport, and Mascot formations in WBW. These features, including the residual chert, are derived from the inert residue that remains after the carbonates have been stripped from the underlying bedrock. It must be pointed out that the carbonate, bedrock features that geologists use to make distinctions between the members of the Knox Group are not necessarily the same as the soil and saprolite features that are utilized by pedologists. Indeed, as the carbonate content of a rock increases, the similarity between bedrock and the inert residue decreases. Increasing age and intensive chemical and mineral weathering also tend to result in the formation of similar soils from fairly diverse but relatedsoil parent materials such as the rocks of the Knox Group. 
Soil map units in this section are described by soil series in increasing numerical order.

\subsubsection{Knox Group Residual Soils}

40031, 40033, 40041, 40043, 40044, 40053. These soils formed in residuum of the Copper Ridge formation. The residuum has high silt plus high-clay content and highly variable chert content. Soils of this unit are on doubly convex landforms. The A and $\mathrm{E}$ horizons are very cherty to extremely cherty due to lag chert remaining behind as fines are washed downslope by overland flow. The $\mathrm{Bt}$ horizons beneath vary in chert content from about 5 to $30 \%$. Some included soils that are more than $35 \%$ chert in the subsoil, and others are almost chert-free. The chert is commonly massive, but both oolitic and chalky types are present. The upper part of the subsoil has a uniform red (2.5YR) color and is free of yellow mottles. In some areas, the lower subsoil becomes increasingly mottled in shades of dull yellow because of decreased permeability. Decreased permeability in the lower subsoil can result in the temporary perching of water, which is accompanied by gray colors in reduced water flow zones. Even in well-drained permeable soils, the lower subsoil and the underlying saprolitic materials will have increasing amounts of yellowish color. This particular yellowish color represents saprolite or saprolitic materials that are oxidized and highly leached. Saprolite colors are dominated by yellows and reds, but the red colors are different from the red colors of the upper subsoil. Translocated or neo-formed yellowish red to red clay coats voids and fracture faces in the upper saprolite. Depth to rock is generally deep, probably more than $50 \mathrm{ft}$, and is highly variable. Some drill holes on Chestnut Ridge have penetrated more than $100 \mathrm{ft}$ of saprolite before encountering rock. However, because of Karst geomorphic processes in an acidic humid environment and the way carbonate rock weathers, pinnacles and ledges, either attached or detached, are a common feature of the underlying extremely variable rock topography, and their location is not predictable. Surface depressions, called dolines, are a common surface expression of underground collapse of caverns and solution channels. Some areas of Chestnut Ridge and WBW have higher concentration of dolines than other areas. Most large dolines occur on crestal landforms or at relatively high elevations with respect to the ridgetop; this is evidence of their relatively great geomorphic age and stability. Most depressions in the higher-elevation uplands appear to be stable and do not exhibit evidence of recent subsidence activity. One or more layers of silt have been deposited in many broad shallow dolines. Most dolines with active swallow holes and cave entrances seem to be situated on lower sideslopes where water flow is concentrated or close to present drainageways. Only a few cave entrances or swallow holes were noted in WBW, and they were at low elevations in the watershed.

Because of the high chert content in the upper 40 to $80 \mathrm{~cm}$ of the soil, most areas of these No. 400 soils were not cleared and cultivated. They were apparently 
periodically logged, and there was some woodland pasturing. Current forest vegetation ranges from stands dominated by chestnut oak to stands dominated by white and red oak. However, based on observations further east along Chestnut Ridge, better forest stands of white oak, red oak, and tulip poplar tend to be underlain by either pinnacles, ledges, or bedrock that are closer to the surface where long-lived tree roots can encounter them and cycle calcium to the surface. Forest that is dominated by chestnut oak with a vaccinnium ground cover is generally over areas of colluvium or residuum much deeper to rock, or in areas where there are few if any pinnacles and tree roots do not encounter rock, or in areas that were badly eroded in the past with loss of most surface soil fertility. Forest stands on Chestnut Ridge are still in the process of adjusting from the demise of chestnut trees, which dominated the canopy at one time. Past land-use practices of partial clearing, pasturing, and burning increased overland flow and the removal of nutrient-rich 0 and $A$ horizons. Based on numerous observations elsewhere on Chestnut Ridge, regrowth of trees on these eroded areas seems to follow different successional pathways than on other areas not as disturbed. Indeed, certain tree species (among other indicators) were used to indicate the presence of old fields in WBW.

Some areas of these soils that were severely to very severely eroded from past agricultural activities are identified by the presence of the digits " 3 " or " 4 " in the fifth place of the identification symbol. Eroded areas have lost most of their original $A$ and $\mathrm{E}$ horizons, with the newly formed $\mathrm{Al}$ and older Ap horizon resting directly on the clayey subsoil beneath. Eroded soils become-saturated in the uppermost horizons very quickly. Consequently, they tend to generate overland flow more quickly than do adjacent uneroded soils. Rainwater infiltrates rapidly and moves downward to the top of the clayey subsoil. Here, water tends to perch and then move either downward under hydraulic head as saturated flow in macropores or laterally downslope in the lower portion of the $E$ horizon. During heavy rains, the $\mathrm{E}$ horizons of these soils usually saturate, and during late winter, they are often saturated for extended periods.

The soils in these map units classify as Typic Paleudults; clayey, kaolinitic, thermic.

40151. These soils formed in surficial creep materials and the underlying residuum of the Copper Ridge formation. They occur in protected, shaded, and cool northeast and east aspects on the north side of Chestnut Ridge and on steep, shaded slopes of larger drainageways. They have a thicker and darker A horizon and a darker and less distinct $E$ horizon beneath than the adjacent No. 400 soils, which occur on southerly and westerly aspects. Most areas of these soils also occur on obsequent scarp slopes where the rock dips into the slope, resulting in greater retention of subsurface water flow. Rock outcrops occur with . a higher frequency in areas of these soils elsewhere on Chestnut Ridge, but none was observed in the watershed. The higher nutrient content in the thicker and darker A horizons of the No. 401 soils compared with the No. 400 soils is also 
reflected in the forest vegetation composition, including canopy trees and the forest floor vegetation. Especially noticeable is the presence of sugar maple saplings on other parts of Chestnut Ridge that are growing thickly in areas that were partially logged about 10 to 15 years ago.

The soils in this map unit classify as Typic or Humic Paleudults; clayey, kaolinitic, thermic.

40221, 40222, 40231, 40241, 40242, 40243, 40251, 40253, 40261. The soils of these map units formed in saprolite weathered from dolomite of the Cheputtepec formation. These soils are on low. upland summits and convex sideslopes in relationship to the higher Copper Ridge and Longview landforms. Depth to hard carbonate rock tends to be deeper beneath these soils than for any of the other formations of the Knox Group. Mapping units differ primarily by slope and past erosion classes. Because some areas of these soils had lower surface chert content, they were farmed in the past. The A and $E$ horizons of these soils have higher chert content than subsoil horizons because of the lag gravel effect. Lag gravel consists of inert materials that have been "let-down" on the current land surface by the removal of silt and clay-sized particles, an effect of past geologic erosion.

The uppermost Bt horizon in uneroded soils has a 10YR or 7.5YR hue and a clay loam texture, but the lower clayey horizons become redder in 5YR and 2.5YR hues, and the amount of bright yellow colors from saprolite increases with depth. Subsoil chert content is highly variable, ranging from less than $5 \%$ to more than $35 \%$ by volume, and its occurrence is not predictable. Eroded phases have lost most of their original $A$ and $E$ horizons and have an old plow layer (Ap) horizon in which a new Al horizon is forming.

Rainwater infiltrates rapidly and moves downward to the top of the clayey subsoil. Here, water tends to perch and then move either downward under hydraulic head as saturated flow in macropores or laterally downslope in the lower portion of the $E$ horizon. During heavy rains, the $E$ horizons of these soils usually saturate, and during late winter, they are often saturated for extended periods.

The soils in these map units classify as Typic Paleudults; clayey; kaolinitic, thermic.

40321, 40331, 40341, 40351, 40361. The soils in these map units formed in a thin layer of surficial creep or ancient colluvium and the very cherty underlying saprolite that weathered from the Longview formation. Soils in these units occur only on narrow ridgetops and summit shoulders. The surficial soils of the Longview formation occupy a strip $15 \mathrm{~m}$ to about $20 \mathrm{~m}$ wide. They could not be mapped at a scale of 1:12,000 without distortion, but they can generally be mapped at a scale of 1:1200 to 1:2400. Blocks of dolomoldic chert on the surface 
tend to help identify the presence of the Longview formation. However, other chert from the Kingsport formation has in places also been let down onto the Longview and does not have dolomolds. Dolomoldic chert from the Longview has also been let down onto Chepultepec and Kingsport soils downslope. However, dolomoldic chert in substratum saprolite usually confirms that the soil formed in Longview residuum. Most areas of these soils were never cleared and farmed because of the high chert content on the surface and within the soil. These soils have a very thick, very cherty to extremely cherty $E$ horizon that extends to a depth of 60 to $80 \mathrm{~cm}$. Depth to the red (2.5YR hue) clayey Bt horizon is commonly 75 to $90 \mathrm{~cm}$. The colluvium that is derived from the Longview soils has a very high chert content throughout, and the footslope colluvial soils below are loamy-skeletal, with more than $35 \%$ chert by volume throughout the soil.

These soils have limited extent but their location and extent can be important for some land uses where high surface chert content and subsoil chert content is a limiting consideration. Because of the high chert content, Longview soils have low water-storage capacity. Trees tend to be subjected to several drought-stress cycles during the summer. Consequently, only trees and ground cover that tolerate drought stress will grow well on these soils.

The soils in these map units classify as Typic Paleudults; clayey-skeletal, kaolinitic, thermic.

40431, 40432, 40433, 40441, 40442, 40443, 40451, 50453. The soils in these map units formed in residuum weathered from the Mascot formation. These soils have a more-intense red upper subsoil than the adjacent No. 406 Kingsport soils. In addition, the subsoil has a much more plastic consistency. The presence of sandstone fragments and chert matrix sandstones on the surface and in the residuum serve as additional indicators. Because of the sandstone fragments, these soils often have a higher sand content in the surface; with loam or fine-sandy loam rather than silt loam textures. These soils do not have any exposed rock outcrops, but carbonate rock is evidently close enough to the surface that lime-loving trees such as redbud tend to grow well on these soils. Because these soils evidently had higher natural fertility, they were more intensively farmed during the past, and many areas were severely eroded before abandonment.

Because of the closeness of bedrock to the surface, these soils have slightly higher base cation status and higher cation exchange capacity because the clay minerals are less weathered. Tree roots are apparently able to tap into the weathering front at the rock-saproliie interface and cycle calcium to the surface. As a result, tree growth and species diversity of both the overstory and ground cover appears to be higher in WBW. Depending on depth to rock, the soils in . these map units classify as Typic Hapludalfs, Ultic Hapludalfs or Typic Halpudults; fine, mixed, thermic. 
40531, 40541, 40551, 40561. Within these map units are few to many areas of ledges and pinnacle outcroppings of rock. The soils in these map units formed in saprolite weathered from the uppermost Mascot formation. They are adjacent to the Unit A soils of the Chickamauga Group, which are close to but not included along the southern side of the watershed. The type of chert in the Mascot (jasperoid and chalcedonic) helps to identify these soils and was used to separate them from the Kingsport No. 406 soils which contain soft chalky chert to the north and the Unit A Chickamauga soils to the south which contain blocky brick-shaped tabular chert.

The presence of pinnacles and ledges, especially noticeable on steeper slopes, is a common surficial feature of the landscape. Karst depressions are also a common landscape feature. The soils have a cherty or very cherty lag gravel surface and upper subsoil and a highly variable chert content in the lower subsoil. Depth to rock is also highly variable.

Because of variable depth to rock and numerous karst features, these soils and their landscapes should be managed for forest and wildlife purposes. They are not suited for other more-intensive uses. The soils in these map units occur as a complex. Some soils classify as Typic Hapludults; clayey, mixed, thermic. Some soils classify as Ultic Hapludalfs; fine, mixed thermic, and some are Typic Hapludalfs; fine, mixed, thermic.

40621, 40622, 40631, 40632, 40633, 40641, 40643, 40651, 40653, 40661. These soils formed in saprolite weathered from the Kingsport formation. They have a variable subsoil chert content, which approaches $15 \%$ by volume. Subsoil chert in the lower part of the formation is quite soft and chalky, appearing to be highly weathered and serving as an indicator for these soils and their separation from the adjacent Longview soils. The Bt horizon is red (2.5YR hue) in the upper part and does not exhibit much evidence of pedogenic degradation. Eroded phases of these soils have lost most of their original $A$ and $E$ horizons. These particular eroded soils have an old plow layer in which a new A horiion is forming. In the most eroded areas, clayey subsoil is just below the surface horizon. The lower subsoil stays redder with depth than most other Knox Group soils. Most soils underlain by the Kingsport are deep to rock and have few if any outcrops. Areas with ledges and rock outcrops were mapped as Soil No. 407. The soils in these map units classify as Typic Paleudults; clayey, kaolinitic, thermic.

40751. The soils in this map unit formed in saprolitic residuum of the Kingsport formation. Outcrops of dolomite are a common surface feature. The upper soil horizons have a very high lag chert content. Chert content is also relatively high throughout the lower subsoil. Because the slopes on which these soils are found are quite steep, they have relatively thin sola. Clay-plugged saprolitic soil occurs at a depth less than $100 \mathrm{~cm}$. Depth to rock is also highly variable. Because of variable depth to rock and numerous karst features, these 
soils and their landscapes should be managed for forest and wildlife purposes. They are not suited for other more intensive uses. In these soils rainfall probably reaches rock quite quickly. One cave opening occurs in this map unit. The soils in these map units occur as complexes. Some soils classify as Typic Hapludults; clayey, mixed, thermic. Some are Ultic Hapludalfs; fine, mixed thermic; and some are Typic Hapludalfs; fine, mixed, thermic.

40851, 40861. The soils in these map units formed in thick residual chert beds of the Chepultepec formation and have been mapped only in' WBW on south-facing dip slopes. The upper soil horizons have a very high chert content. The subsoil has a high content of sharp-edged chert, 'and 'chert content' increases with increasing depth. Chert beds in the Chepultepec formation have a limited distribution and have been mapped only in a small area of WBW. Because of their

high chert content and steep slopes, these soils were never farmed, but were probably logged one or more times. Trees growing on these soils are probably tolerant of low fertility and drought conditions. The soils in this map unit classify as Typic Paleudutts; loamy-skeletal, kaolinitic, thermic.

\subsection{Knox Colluvial Soils}

Most Knox colluvium has a rather high chert content, ranging from about $15 \%$ to more than $50 \%$ by volume. Colluvium is generated by several processes. One process occurs whenever the upper part of upland residual soils becomes saturated with a consequent loss in stability. The saturated mass flows downslope as a mud and covers the slope below. Another process is colluvium generated by bioturbation. Trees are overthrown, and the upturned roots bring soil above the surface. As the roots decay, soil is let-down the slope a few meters. This process produces a particular kind of microrelief that is commonly called "cradle-knoll" or "pit and mound." The colluvium generated by this particular process has a sporadic distribution on the landscape and accounts for the sporadic distribution of colluvial pockets in larger areas of residual upland soils. Another geomorphic process that generates colluvium is creep. Creep is a very slow process in which soil material is very slowly transported downslope under the primary influence of gravity. Creep processes also slowly move windthrow soil mounds downslope. it is difficult to distinguish creep materials from bioturbated materials (soil disturbed by the growth of roots). However, creep processes are more active on steeper slopes and the local colluvium has a more general and more uniform distribution over the hillslope in contrast to colluvium produced by bioturbation.

Knox colluvial soils were identified and separated in mapping according to several criteria including (1) soil morphology and chert content, (2) landscape setting, (3) age, and (4) minimum thickness. Colluvial soils were mapped only when the colluvium was more than $50 \mathrm{~cm}$ thick, a thickness that appears to affect near-surface lateral water-flow pathways. Colluvial soils were also separated, 
depending on the presence or absence of fragic subsoil properties, often identified by pale brown mottles, brittleness, compactness, and direct evidence of its ability to perch water. Fragipans, or subsoil layers with fragic properties that perch water, occur only in some colluvial soils. Colluvial soils with fragipans occur on low toeslopes in the watershed but have a sporadic distribution that cannot be mapped at a scale of 1:1200 to 1:2400. Colluvial soils on doubly concave landscapes, commonly with fragic properties, were separated from nonfragic colluvial soils that occur mostly on convex landscapes. Knox colluvium spans a wide range in age, from Tertiary to at least Late Pleistocene. Ancient Knox colluvium has undergone topographic inversion and now occupies some of the highest elevations on Chestnut Ridge. Pleistocene colluvium occurs in saddles and other concave footslope and toeslope landforms. Most Knox footslope colluvium has one or more time discontinuities, an indication of more than one major episode of geomorphic instability. The presence of fragic subsoil layers, fragipans, or glossic zones always marks such a discontinuity in these soils.

Loess has also been deposited throughout the Pleistocene, with the latest significant deposition occurring about 12,000 to 25,000 years ago during the melting of the Wisconsinan glaciers. Most of the loess either mixed into the upper soil horizons by biotic activity or was washed downslope into depressions or onto gentle toeslopes and preserved beneath younger cherty slopewash or removed entirely from the area. Only at scales of 1: 1200 to 1:2400 could loess-derived soils (Soil No. 438 and 439) be mapped in dolines.

43021, 43023, 43031, 43033, 43041, 43042, 43043, 43051. The soils in these map units formed in a minimum of $50 \mathrm{~cm}$ to several meters of colluvium derived from residual soils of the Knox Group. The No. 430 soils are similar in some respects to the ancient colluvium No. 436 soils, but the No. 436 soils are only mapped in the highest places on hilltops and have no current source area of colluvium. The No. 430 soils generally have more than $15 \%$ chert by volume throughout and can range to more than $50 \%$ by volume in some areas, depending on the chert content in the residual soils above. These soils occur in saddles and below saddles to the heads of drains but have a colluvial source in residual soils above them. These soils also occur on lower sideslopes and commonly have a doubly concave slope configuration. Most areas of these soils have a restrictive layer that perches water during wet periods. This restrictive layer commonly occurs at a depth of 80 to $125 \mathrm{~cm}$ below the surface and is more pronounced where slope forms are doubly concave. The restrictive layer, identified by the presence of 10YR 6/3 mottles, locates a discontinuity and the presence of an older, often truncated paleosol, that formed in either an older colluvium or in residuum beneath. Some areas of these soils have a fragipan, but the fragipan is intermittent. Most of the surficial colluvium is of late Pleistocene age, with the latest period of upland denudation and downslope mass movement occurring during the Wisconsinan stage of glaciation. The No. 430 colluvial soils have not experienced topographic inversion. Where topographic inversion has occurred, 
the ancient late Tertiary or early Pleistocene colluvial soils are identified as No. 436 soils on the soil map.

The dominant subsurface water flow in these soils is lateral downslope. Because of the extensive lateral water flow, these soils are highly leached and extremely acidic, Forest vegetation does not seem to be as productive on these soils, in contrast to the Knox No. 433 and No. 434 colluvial soils. Thickness of colluvium varies from about $50 \mathrm{~cm}$ on upper concave sideslopes to $1 \mathrm{~m}$ or more on some low footslopes. These soils have a very high capacity for the lateral downslope transmission of water, with water perching and flowing above the fragic layer. During periods of late winter and early spring, the soil above the fragic layer is often saturated with shallow pits and drill holes that fill 'rapidly 'under these wet conditions. However, during the summer, these soils dry out and become very droughty as plant roots extract the soil water from above the fragic layer. Some roots do penetrate the fragic layer and can extract water from deeper parts of the soil. The high chert content of these soils also reduces water-storage capacity. Perching of water can occur at several depths in these soils. On steeper hillsides, where colluvium ranges from $50 \mathrm{~cm}$ to about $80 \mathrm{~cm}$ thick, perching occurs at the contact with the colluvium and the truncated residual soil beneath. If perching lasts long enough to allow biologic activity to reduce the oxygen content of water to very low levels, a process of ferrolysis can begin. Ferrolysis is a process in which iron is differentially reduced in some part of the perched zone, translocated laterally or downwards, and precipitated out as coatings on ped faces or eventually forming a nodule. This process produces the typical drainage mottling and, especially, the formation of pale brown (10YR 6/3) mottles. Ferrolysis, in addition, also destroys clay minerals with the subsequent release of silica and aluminum plus whatever base cations might be present in the clay mineral. The aluminum is often incorporated into the mineral lattice of vermiculite, transforming this mineral into hydroxy interlayered vermiculite. The silica and aluminum may also recombine in the perched zone as an-amorphous alumino-silicate, which acts as a cementing agent in the formation of a genetic fragipan, or the aluminum and silica can recombine lower in the soil to form the clay mineral kaolinite. Iron, released by this process is translocated to lower positions in the soil where drainage mottles are formed. Where these soils occur on more-concave footslope and toeslope landforms, the thickness of colluvium increases, and there is usually more than one layer of colluvium. In these low landforms,' water can perch at several depths. The soils in these map units classify as Fragic Paleudults; loamy-skeletal or fine-loamy, siliceous, thermic.

43121, 43131, 43141. The soils in these map units formed in Recent and Modem deposits of slopewash where surface soil washed from higher slopes has accumulated to a depth of more than $50 \mathrm{~cm}$. A buried soil always occurs in these soils within a depth of $100 \mathrm{~cm}$. These soils have very limited extent in the watershed and are mostly situated in dolines and drainageways along the eastern 
WBW boundary in old agricultural fields The soils on these mapping units classify as Fluventic Dystrochrepts; fine-loamy, siliceous, thermic.

43351, 43353, 43361. These soils formed in soil creep materials of varying thicknesses and in the underlying Knox Group residuum. They occur only on shaded east and northeast aspects. The surface layer is dark from the high organic matter content and $18 \mathrm{~cm}$ to more than $25 \mathrm{~cm}$ thick. The clay enriched subsoil has a yellowish-brown color. Windthrow cradle-knoll microrelief is a common surface feature of these soils, Included in mapping are small areas of soils with higher base saturation caused by the proximity to rock pinnacles or ledges to the surface. One area of these soils in WBW was farmed, became severely eroded, and is identified by the No. 43353. Numerous shallow gullies formed either before abandonment or after the area was abandoned and before the land surface was stabilized by forest vegetation. The soils in these map units are classified as Humic Hapludults and Typic Paleudults; fine-loamy and loamy-skeletal, siliceous, thermic.

43421, 43431, 43432, 43433, 43441, 43433, 43451. These soils formed in colluvium between 50 and $125 \mathrm{~cm}$ thick and in the underlying Knox Group clayey residuum. These soils occur on landforms that are mostly convex in contrast to the No. 430 soils, which occur on landforms that are more concave. The No. 434 soils have subsoil colors that are brighter and less yellow than the No. 430 soils, and they have no evident subsoil layer that perches water. Included in mapping are areas where depth of colluvium is less than $50 \mathrm{~cm}$, and small concave portions of the landform where colluvial soils with subsoil fragic layers occur. Because of the rapid infiltration of rainwater and the rapid subsurface lateral flow in these soils, they are rarely saturated. The soils in these map units classify as Typic Paleudults; fine-loamy, siliceous, thermic.

43621, 43631, 43641. The soils in these map units formed in ancient toeslope colluvium and ancient local alluvium that through topographic inversion now occupies upland summit landscapes. Soils in these map units are mapped only on broad, stable high-elevation upland summits on Chestnut Ridge and are generally underlain by the Longview formation and parts of the Chepultepec and Kingsport formations on either side. In WBW some areas of No. 436 soils are underlain by Copper Ridge residuum. The No. 436 soils have a thicker and more strongly expressed $E$ horizon than the younger No. 430 and No. 434 soils that occur on recognizable colluvial landforms. A paleosol that formed in very cherty residuum commonly occurs beneath the colluvium. The chert fragments in this old paleosol are highly weathered, most are soft and easily broken by augering, indicating a long age of weathering. Chert fragments in the ancient colluvium are also highly weathered and commonly impregnated with iron oxides. Downslope from delineations of these No. 436 soils, it is common to find adjacent areas of the No. 990, No. 991, and No. 994 soils that formed in ancient alluvium. Both these No. 436 soils and the related No. 990, No. 991, and No. 994 soils have a probable 
mid to late Tertiary age considering the time required for topographic inversion and reddening of the No. 990 alluvium.

Some areas of these soils were cultivated in the past and were moderately eroded. The thickness of ancient colluvium that remains is highly variable, ranging from less than $50 \mathrm{~cm}$ to more than $150 \mathrm{~cm}$. The soils in these map units classify as Typic Paleudults; loamy-skeletal, siliceous, thermic.

\subsection{Doline Soils}

Most Dolines in WBW of larger diameter are associated with topographically inverted, former footslope, toeslope, and terrace landscapes and are of considerable age. Dolines with broad, nearly level bottoms contain distinctive soils. Soil materials have been periodically added to the surfaces of preexisting doline soils and then preserved, unless the doline sidewall has been breached. The lowermost paleosol of large dolines typically has a very high chert content, and appears to have a colluvial origin. Its major source was from the sidewalls as the doline increased in diameter, although some increase in content was a result of clay washing from the residuum that slumped into the bottom. In larger and broader dolines, a layer of compacted sift loam occurs immediately above this very cherty layer. This stratum contains from none to a few pea-sized, soft, chert fragments. This particular stratum was evidently deposited in standing water. A cherty stratum mantles this lowermost, mostly chert-free silt layer and probably represents a time when slope erosion processes were more active. Above this cherty stratum, another layer of high-silt-content materials was deposited, again in a very wet environment. Within this stratum a complete paleosol has often been preserved. Above this particular stratum, there is another thin layer of larger chert fragments. Above this paleosol, another layer of high silt content soil material, presumed to have a mostly loessal origin, has been deposited. It has very few pea-sized chert fragments. A soil horizon sequence has formed in this stratum. This stratum occurs at the surface in dolines that are forested. However, where dolines occur in cultivated areas, this high-silt-content stratum has been buried by Modern Age cherty slope sediments that are $25 \mathrm{~cm}$ to more than' $100 \mathrm{~cm}$ thick. Colluvium, of presumed Wisconsinan age, has covered the uppermost silty layer around doline margins. The history of most dolines in WBW is one of formation, infilling, and enlargement; a wet period or periods when ponded water occurred; and the more recent infilling and drying during the Holocene. Periods of 'infilling or of subsidence activity are probably associated with Pleistocene climate changes producing increased rainfall. The youngest surficial materials in many dolines is derived from soil eroded from hillsides after clearing. Charcoal fragments are abundant in this most recently buried surface. A discussion of dolines and their stratigraphy is contained in TM-I 1364 (Lietzke, Ketelle, and Lee 1989).

43721, 43731, 43741. The soils in these map units formed in a layer of loess, high-silt-content slope wash, and the underlying very cherty to extremely cherty 
colluvium. These soils occur in some dolines that have broad shallow bottoms and on broad gently sloping hilltops underlain by ancient colluvium. A well-developed but highly degraded fragipan occurs at the contact of the loess and the cherty colluvial soil materials beneath. These soils have very limited extent. The soils in these mapping units classify as Typic or Glossic Fragiudults; fine-silty over loamy-skeletal, siliceous, thermic.

43821, 43831. The soils in these map units formed in loess or high-silt-content slopewash materials that are $50 \mathrm{~cm}$ to more than $100 \mathrm{~cm}$ thick and occur only in the broad bottoms of well-drained and moderately well-drained dolines. These soils are very similar to the No. 439 soils but are better drained. The high-siltcontent material is commonly capped with a thin layer of Modern Age slopewash, having a few to many chert fragments. The paleosol beneath generally has a completely preserved genetic soil horizon sequence, but the buried A horizon has lost its organic component and now has a grayish bleached-out appearance. At some depth below the loess, another paleosol occurs in cherty or very cherty colluvium. In some broad and stable doline bottoms, there are two layers of loess, commonly separated by a thin layer of silty slopewash that contains some chert fragments. Not all dolines that are shown on the surficial geology map have loess deposits in them. Dolines with a funnel-shaped bottom generally have only very cherty slopewash in their lowermost portions. Dolines with breached sidewalls commonly have lost their silty strata and contain only very cherty sediments. These dolihe soils have very limited extent and can be mapped only at scales of $1: 2400$ or $1: 1200$. The preservation of strata in dolines is important in that a history of some past geomorphic events has been preserved. On smaller-scale soil maps, dolines are shown by spot symbols, and the soils in their bottoms cannot be mapped. The soils in these mapping units classify as Typic and Aquic Hapludults; fine-silty, siliceous, thermic.

43911, 43921. The soils in these map units formed in one or more layers of loess and the underlying cherty colluvium. (Two distinct layers of loess have been identified thus far.) Surficial loess thickness is $50 \mathrm{~cm}$ to more than $100 \mathrm{~cm}$. These soils become increasingly gray with depth, although there are some places where surficial water is perched by palic fragipans that formed in the underlying colluvial paleosol before it was buried by the loess. These soils have very limited extent and can be mapped only at scales of 1:2400 or larger. The soils are important in acquiring an understanding of the past geomorphic processes and events that have shaped the surrounding landforms. Very small dolines are shown on the soil map with a spot symbol. The soils in these map units are classified as Aeric and Typic Ochraquults; fine-silty, siliceous, thermic. 


\subsection{OLD ALLUVIUM}

Geomorphic process of the past are preserved in scattered locations in WBW. Ancient streams deposited sediments in floodplains and on terraces. Subsequent processes of erosion and topographic inversion have resulted in these alluvial deposits being located on some of the higher elevations of Chestnut Ridge. Old alluvium on the site has both local (contains local chert) and distant sources (meta quartzites from the Unaka mountains). Main-channel ancient alluvium has a darkred clayey subsoil and few, if any, chert fragments, whereas ancient alluvium of a more local source area has a higher content of highly weathered and iron impregnated chert fragments. Most of the ancient alluvium on the site occurs on the upper Copper Ridge formation, where it blankets southeast-facing slopes. Subsequent erosion processes and the headward migration of drainageways have removed some of this ancient alluvium. The thickness of ancient alluvium on Chestnut Ridge'ranges from 'less than $1 \mathrm{~m}$ to about $6 \mathrm{~m}$, as revealed in one drill hole located in the East Chestnut Ridge area'and several boreholes located-in the West Chestnut Ridge area of the Reservation.

99031, 99042, 99043, 99053. The soils in these map units formed in alluvium of probable late Tertiary or early Pleistocene. Today, these soils occupy some of the higher elevations on Chestnut Ridge. Most areas of these soils were preserved on southeast and south slopes, which tend to be more geomorphically stable, and are mostly underlain by residuum of the upper Copper Ridge formation and the lower Chepultepec formation. The No. 990 soils have not been mapped over the Kingspott, Mascot, or Chickamauga Unit A formations on Chestnut Ridge or in WBW.

The No. 990 soils have a thick, dark surface layer and dark-red clayey subsoil horizons. Most areas of these soils have very few coarse' fragments, and only fragments resistant to weathering remain. These are chert of local origin and metaquattzites from the Unaka Mountains of Upper East Tennessee or perhaps Chilhowee Mountain that have been impregnated with maghemite and iron oxides. Another key indicator of these soils is the presence of numerous small, 1- to 2-mm-diam hard iron-manganese nodules throughout the soil, nodules that do not occur in adjacent residual or colluvial soils.

Because of their generally favorable physical properties, nearly all areas of these soils were in agriculture when the Reservation area was taken over by the AEC. Because the soils are relatively permeable, they were. not all severely eroded, although there are some severely eroded areas. The soils are sticky when wet because of the high iron oxide content, but they dry rapidly and become very friable and have a strong granular or blocky soil structure. These soils are the alluvial remnants preserved from an earlier erosion cycle. Several questions remain about how these soils became dark red, including What is 'the "source of all the iron oxide? Was the iron oxide translocated from higher landforms when 
these soils were in floodplain and terrace landforms? Today, except for the occasional rounded river slick gravel, it is difficult to imagine that these soils were once in low-lying but well-drained floodplain landscapes with hills rising from their edge. The current distribution of iron oxides and their color suggest that these soils were not subjected to a long period of fluctuating water tables. If they had been, then the iron would have been organized into hard nodules, with a pale soil matrix between nodules. Typically, these soils are identified by the numerous iron nodules that are about 1 to $2 \mathrm{~mm}$ in diameter. This soil feature would suggest that these soils were once in a fluctuating water table zone, a condition required for the migration of these oxides into hard nodules. However, as rivers shifted course and continued to downcut, the soil would have become better drained. It would seem that further additions of iron would be necessary to form the dark-red colors observed today. There are at least two possible sources of additional iron that are now disseminated throughout these dark-red soils. One source is deposition from the air, the other iron sources are weatherable biotite and chlorite minerals carried from the Unakas by an ancestral Tennessee River. The soils in these map units classify as Rhodic Paleudults; clayey, oxidic, thermic.

99121, 99131. The soils in these map units formed in a thin layer of Late Pleistocene loess $50 \mathrm{~cm}$ to about $100 \mathrm{~cm}$ thick, with the underlying old local alluvium and residuum beneath. These soils typically have two or more clay-enriched subsoil horizons. The upper subsoil formed in loessal materials. It is yellowish-brown and has a silt loam-silty clay loam texture. The lower clayenriched subsoil formed in the underlying old alluvium. This particular subsoil layer has a redder but often mottled color, caused by perching of water, and a clay loam or silty clay loam texture. Maghemite nodules, 2 to $3 \mathrm{~cm}$ in diameter, and iron-impregnated chert fragments are a common feature of the old alluvium and help to identify its presence. The underlying soil materials are highly weathered cherty residuum. These soils occur on dissected terrace landforms close to the crest of the residual soil hills. They have undergone topographic inversion, an indication that their absolute age is quite old. The greater permeability of the alluvium compared with the surrounding clayey residual soils allowed for greater geomorphic stability, thus preserving these ancient soils. The permeability of the alluvium also allowed for the preservation of loess. The surficial loess is presumed to be of Wisconsinan age, or about 19,000 to 23,000 years ago. Older loess would have been mostly washed off. However, some soil borings revealed the presence of an older loess with a yellowish-red color and a silty clay loam texture beneath the younger yellowish-brown uppermost loess. The soils in these map units classify as Typic Paleudults; fine-silty, siliceous, thermic.

99421, 99431, 99433, 99441, 99443. These soils are on broad upland summit landscapes. They formed in a mixture of ancient local cherty colluvium and alluvium and the underlying Knox clayey residuum and were mapped whenever the surficial materials were more than $50 \mathrm{~cm}$ thick. These soils originally occupied low toeslope-terrace landforms where alluvium and colluvium accumulated. 
Subsequent topographic inversion has transformed these once low-elevation landforms. The soils in these map units have subsoils that contain less clay than nearby residual soils. Subsoil colors also tend'to be redder than the adjacent residual soils but less red and with lower clay content than the adjacent No. 990 ancient alluvial soils. They are also very similar to the No. 991 soils but lack the loess capping. A more important indicator of these soils is the highly weathered and iron-impregnated nature of the chert fragments. Maghemite is a common feature of these soils, and its presence helps in their identification. Many chert fragments are quite soft and have partially converted to kaolinite. Other chert fragments have a red rind. These soils usually occupy a transition zone between the No. 436 soils, which were stripped free of iron and manganese oxides, and the No. 990 soils, which have red and dark red subsoils and abundant iron-manganese nodules. Where these soils occur near the No. 436 soils, they have a higher chert content and a less-red-color, whereas areas near No. 990 soils have redder colors, higher clay content, and less chert. As mapped on Chestnut Ridge and in WBW, the No. 994 soils represent at least two erosion cycles. Ridgetop areas of No. 994 soils represent the remnants of the oldest cycle. Other areas of No. 994 soils are mapped at a lower elevation elsewhere on Chestnut Ridge on old fan-terrace landscapes but are still high above present areas of toeslope and fan-terrace colluvium-alluvium deposition. The extent of the No. 994 soils is not large, but the age and geomorphic history of these soils and the associated No. 436 and No. 990 soils is important in determining both the ages of landform surfaces and the development of karst geomorphic features. The soils in these map units classify as Typic Paleudults; fine-loamy, siliceous, thermic.

99922 The soils in this map unit classify as Typic Hapludults; fine-loamy, mixed, thermic. (Sequatchie-like.) These soils occur in one area in WBW. They are located in the East Fork area, at the confluence of two tributaries. An old home site is located on this fan terrace landform. These soils are considered to have a late Pleistocene or early Holocene age. They have a high content of very fine sand and silt throughout the upper profile and a yellowish brown Bt horizon with a silt loam or light clay loam" texture. The soils are underlain by extremenely cherty alluvium. They have segregated iron-manganese zones in the subsoil but no hard nodules, an indication that sediment deposition ceased in the late Pleistocene to Early Holocene, or about 20,000 to 18,000 years ago.

These soils are classified as Typic Hapludults; fine-loamy over loamy-skeletal, siliceous, thermic.

\subsection{RECENT ALLUVIUM}

98031, 98041. The landforms and soils in these units occur as a complex that comprise the coves and narrow drainageways and coves of Chestnut Ridge and WBW. The Udifluvent soils occur in floodplains and narrow bottoms. They are 
stratified and show minimal evidence of soil genesis, Textures are cherty to extremely cherty silt loams and loams. The Fragiudult and Paleudult colluvial soils occur in narrow strips on toeslopes that are usually too small to delineate but are important in hydrology and land use. Also included in the colluvial parts of the landscape are small alluvial fans from recently cut gullies, the results of past land mismanagement from both farming and forestry. Old farm or logging access roads are a common feature in areas of these soils, especially in wider drainageways. Most of the soils in these mapping units are well-drained but some areas, where small seeps and springs occur, are wet. Knick points, entrenched channels, and overwashed zones occur throughout the Udifluvent soil areas, giving rise to a complicated sequence and pattern of soils. Fragipans commonly occur in low colluvial soil areas. In addition there are areas without fragipans and areas that have fragic subsoil properties. Some toeslope areas have been covered by modern slopewash from agricultural fields on the slopes above. Most vegetation on these soils is forest, ranging from tulip poplar to red maple, and Paw Paws are common in some moist drainageways. Some areas of these soils have abundant cobble-sized and boulder-sized chert on the surface and in the soil. Most rainfall and run-on water from higher slopes infiltrates and flows downward and laterally in these soils. Consequently, these soils have a tendency to become filled with water during wet periods. Water also perches at discontinuities, but these soils tend to drain freely because of the low clay content, slope, and the pipes that have formed from bioactivity. The soils in these map unit complexes classify as Udifluvents, Fragiudults, and Paleudults; loamy-skeletal, siliceous, thermic.

98121, 98131. These well- and moderately well-drained soils formed in alluvium washed from residual upland and colluvial soils of the Knox Group. The upper part of these soils is derived from Modern Age sediments washed down into drainageways by land clearing and subsequent agricultural activities of European settlers. The thickness of this Modern Age sediment ranges from about $50 \mathrm{~cm}$ to more than $100 \mathrm{~cm}$. The Modern sediments commonly contain one or more buried surface layers, the results of catastrophic local intense storms on bare soils. Buried soils beneath this Modern Age alluvium have a variety of morphologic expression ranging from weak cambic horizons to clay-enriched argillic horizons. The largest area of these soils occurs along the east fork of Walker Branch Creek. However, most areas of these soils occur in narrow drainageways, are mapped as a complex with low toeslope colluvial soils, and are identified by the No. 980 symbol.

The soils in these map units classify as Typic and Aquic Udifluvents; fine-loamy or loamy-skeletal, siliceous, thermic.

98211. The soils in this map unit are located on wet floodplains but are undifferentiated with respect to their morphology and classification. They are somewhat poorly to very poorly drained. Most of the delineations in this unit generally contain springs and seeps that keep the soils wet and saturated most 
of the time. In other areas that are wet, stream channels tend to be poorly defined or else they are very shallow. Only vegetation tolerant of wet conditions grows well on these soils. Small areas of these soils occur as inclusions in larger areas of No. 980 soils. These soils should be kept in a natural 'condition. They are important in maintaining stream water quality regardless of upper-watershed land use. The soils in this undifferentiated map unit classify as Fluvaquents and Ochraqualfs; loamy-skeletal, siliceous, thermic. 


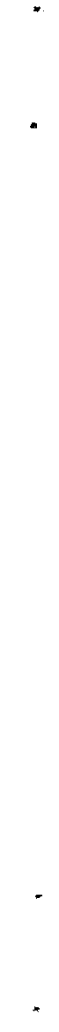




\section{INTERPRETATIONS}

The ability to predict the response of a particular type of soil to a change in land use needs to be known. Many predictions of soil behavior or potential forest productivity are based on (1) past observations, (2) research on the same or similar soils, (3) external and internal forces and processes that influenced rock weathering and soil formation, and (4) the physical, chemical, mineralogical, and hydrologic properties of the soil. Many of the interpretations of Table 1 were developed according to the criteria in the National Soils Handbook (Soil Survey Staff 1983). The rating criteria in the Handbook allow soil scientists to make reasonable estimates of inferred soil properties based on observable soil characteristics. The depth of soil observation for predicting soil 'behavior in the National Soils Handbook is confined to a depth of about $2 \mathrm{~m}$ or to hard rock or dense weathered bedrock (saprolite) if it occurs at a shallower depth. Table 1 lists interpretive ratings for each soil series. Where there is a range in "the ratings, the range is usually related to the slope gradient and its effects on that particular interpretation.

\subsection{DRAINAGE}

Drainage classes are based in the frequency and duration of periods when the soil is saturated. Water may be either perched by some restrictive layer in the soil during wet periods or saturated by the groundwater table. Perched water or groundwater in the soil can be identified by soil color patterns. Soil colors are of two general kinds: colors inherited from'the parent materials (saprolite, colluvium, or alluvium) and colors that are the result of soil formation (oxidation and reduction). Most color in the soil is caused by (1) iron oxides, (2) organic carbon (surface horizon), (3) manganese, and (4) colors that result-when 'water saturates the soil.

When water perches in a soil, the soil is usually not uniformly saturated, but there are areas with high biologic activity where the bacteria remove oxygen from the soil, resulting in anoxic conditions.- In these anoxic areas, manganese and iron are reduced, becoming much more mobile. These mobile forms migrate laterally and downward to areas that are oxidized, where they precipitate out forming either coatings or nodules that have their own stiades of reds and yellows, whereas the reduced zones acquire a pale brown to grayish-brown color. Perched zones usually have a highly mottled color pattern, whereas the more-oxidized-unsaturated zone beneath does not. In those areas where the groundwater table intersects the surface, the upper soil can have a mottled color pattern, but the color becomes increasingly gray with increasing depth. There are only a few areas on the Reservation where the groundwater table comes to the surface. These areas are found below springs and seeps and in drainageways that flow year round. 
Table 1. Soil Interpretations

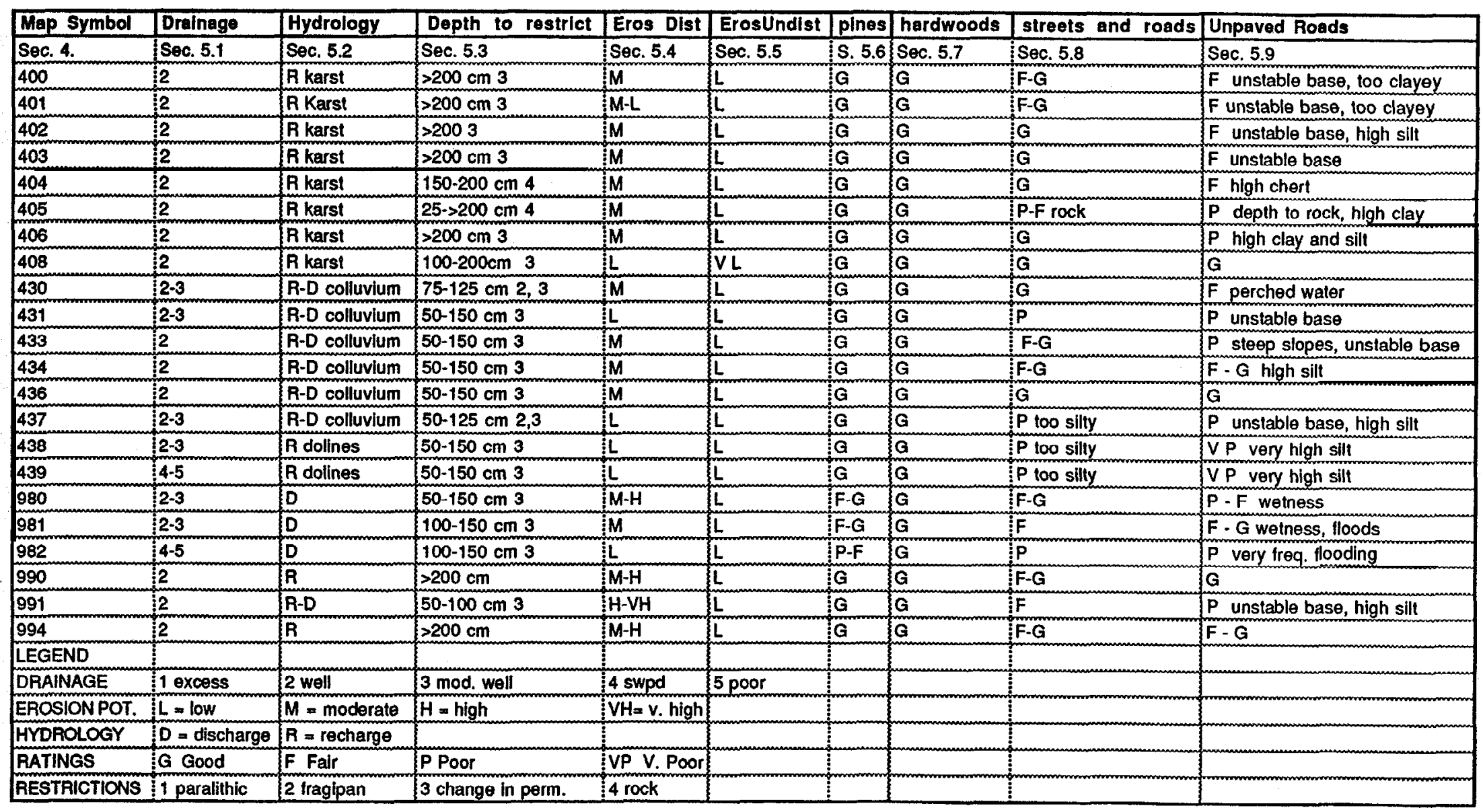


Drainage conditions in soils have traditionally been interpreted for growing agronomic plants during the growing season. Drainage conditions are divided into five classes, ranging from excessively well-drained to very poorly drained. Definitions of these classes are in the Revised Soil Survey Manual (Soil Survey Staff 1964) and are used in this report because other definitions of drainage wetness classes for deeper soil zones do not exist.

\section{2 HYDROLOGY}

Soils and their associated landforms are rated for their capability to allow the downward movement of water to recharge the groundwater or for their discharge potential. Once rainfall has infiltrated the soil surface, it tends to move downward rather uniformly through the surface layer and upper subsoil. However, with increasing depth in the subsoil, water tends to move in preferred pathways, many of which were formed by biologic activity including deep rooting by trees and burrowing by soil fauna, or flow becomes confined to fractures and joints that are preserved in the underlying saprolite. Figure 19 illustrates schematically some pathways of water flow in the soil.

\section{21 Surface Water Infiltration and Near-Surface Water Flow}

Direct infiltration of rainfall, tree drip, or stemflow into the soil is a dynamic process controlled by several factors including: (1) slope gradient; (2) slope shape; (3) presence or absence of surficial organic layers and their hydrophobicity; (4) surface layer soil texture, soil structure and aggregate stability, and macropores; (5) subsoil hydraulic conductivity, including pore size distribution and continuity; and (6) the layer in the soil that has limiting hydraulic conductivity. Rainfall initially infiltrates at its highest rate in either dry or moist bare soil. The ability of a soil to sustain its high rate of infiltration depends on the ability of the soil to transmit this water downward. Whenever the rate of rainfall exceeds the rate of infiltration, overland flow starts. As water moves downward, the rate at which it does so decreases. Once a limiting hydraulic layer is encountered, water will tend to pile up and to saturate flow pathways in the soil. Eventually, the 'surface layer can become saturated. Once this happens, overland runoff can start, even under conditions of less-intense rainfall. Saturated soil layers also tend to lose much of their stability and move downslope if not anchored by roots.

Surface litter can greatly affect the pathways by which- rainfall "eventually gets into the mineral soil. Leaves and needles with high surface wax content and most dry organic matter tend to be hydrophobic. Water beads up on leaf surfaces and tends to puddle. Where the ground surface is covered with a thick layer of waxy leaves, intense rainfall can puddle on the surface and flow off the site without much infiltration. The overlapping leaves act somewhat like a shingle roof. Often, rainfall that beads up on leaves will break through in random places and flow downward 
ORNL-DWG 93-13675

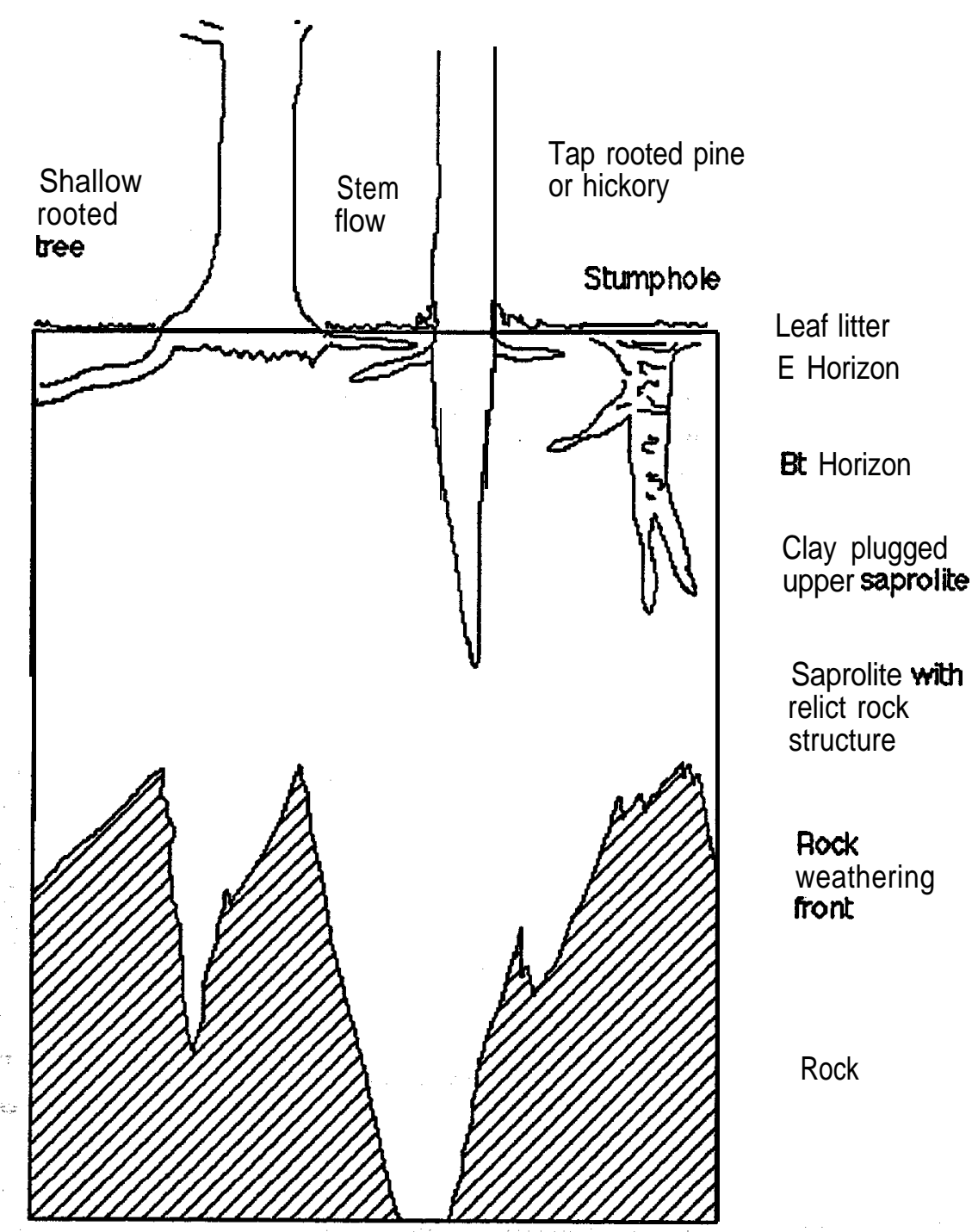

Figure 19. Near-surface soil hydrology on Walker Branch Watershed 
as saturated flow, while in other places the mineral soil does not become wetted. Tree stemflow, once it starts, results in considerable delivery of water into the soil. Stemflow water can evidently penetrate quickly to considerable depth via saturated flow, down existing root channels. Rainfall that initially ponds and flows on the surface litter can also impinge on old stump holes that are filled with leaves. The loose soil and leaves in the stump hole become saturated, as noted in numerous observations. Water leaving old stump holes can also move rapidly downward as saturated flow. This water, because it passes through a thick layer of decayed and decaying leaves, can be enriched with dissolved organic carbon.

Water can perch in a soil whenever the saturated hydraulic conductivity of the soil layer beneath is exceeded. Perched water has a tendency to flow laterally along a hydraulic gradient, In residual soils, water commonly perches during and after heavy rains within the $E$ horizon because the Bt horizon beneath has much slower conductivity. Perched E horizon water also moves readily laterally downslope. Water that perches in the $E$ horizon is responsible for both its pedogenic formation and its thickening over time. Specific kinds of chemical processes take place within an $\mathrm{E}$ horizon that is underlain by a Bt horizon. Water infiltrating through the organic surface layers and the carbon enriched A horizon carry dissolved organics into the $E$ horizon. The presence of these organics plus anaerobic respiration result in the reduction of iron, destruction of clay minerals, and subsequent organic chelation of iron and aluminum. Iron and aluminum are carried downward into the Bt horizon. Here, aluminum can recombine with silica, forming kaolinitic clay, and iron can precipitate as oxides or hydroxides. In addition, downward streaming of water through the $E$ horizon can also transport particulate clay particles into the Bt horizon. Here, translocated clay, neo-formed clay, and clay-oxide complexes coat ped surfaces and pores.

The upper part of the clay-enriched Bt horizon has higher conductivity than does the lower part. Water that gets into the Bt horizon tends to become confined to particular flow pathways in the lower part. Here, water tends to perch again whenever the conductivity of the more-limiting layer beneath is exceeded. Once water has moved through the lower subsoil, it tends to move rapidly via saturated flow in defined pathways and also much more slowly by unsaturated flow away from these saturated zones. Patterns of soil colors in the lower subsoil and saprolite visually define these pathways of saturated water flow. Water usually perches at two or more depths in many residual soils in WBW. Water commonly perches at the base of the $E$ horizon at a depth between about $25 \mathrm{~cm}$ to nearly $80 \mathrm{~cm}$, the depth depending the thickness of the $\mathrm{E}$ horizon. Water also commonly perches in the lower Bt horizon between depths of about 100 to $125 \mathrm{~cm}$, especially in soils with high-clay-content subsoils. Water can also perch in the upper $\mathrm{Cr}$ horizon boundary zone and also on top of hard rock.

The colluvial soils in the soil survey area have slightly different hydraulic conductivity properties than do the residual soils. First, the colluvial soil material 
was once saturated and flowed downslope as a saturated mass to a lower concave slope position, where it achieved some degree of geomorphic stability. This colluvial material underwent a partial sorting as it moved downslope. The clay content was reduced, and considerable iron was removed. Colluvium tends to have a higher hydraulic conductivity, and water tends to readily infiltrate and move downward. However, the contact with the more-permeable colluvium and the lesspermeable paleosol beneath constitutes a limiting layer. Here, water perches and then readily flows laterally downslope. If conditions are right, a fragipan having very limited conductivity forms at this discontinuity. Fragipans are not a common feature of most Reservation and WBW colluvial soils because of the relatively good permeability of the underlying paleosol, but some lower colluvial subsoil layers have some properties of fragipans or show visual morphologic evidence of present or past perching of water. Water usually perches in colluvial soils at the uppermost discontinuity that commonly occurs at a depth of about $80 \mathrm{~cm}$ to more than $125 \mathrm{~cm}$.

Most young alluvial soils, because of their stratified nature, tend to transmit water laterally very easily because the fine strata act as water barriers for downward movement.

\subsection{Water-Flow Pathways Deeper in the Soil}

Most saturated water movement in deeper soil layers and in saprolite is strongly confined along cracks, fractures, and bedding planes. Color patterns, including distributions of iron and manganese coatings in saprolite, can be used to show where water is moving via saturated and unsaturated flow. Water flows away from saturated zones via unsaturated flow mechanisms. Manganese is commonly reduced and mobilized in saturated zones but is then transported laterally away via unsaturated flow. Some but not all chert beds in residual soils derived from the Knox Group tend to be zones in which water moves downward quite rapidly. These water-flow zones have bright-red iron oxide coatings. Manganese, if present, occurs as a crystalline mineral that has been occluded from the system by a thick iron oxide-clay coating. Water, once it reaches a limestone pinnacle, can move downward very rapidly in the thin but very permeable weathering zone between hard rock and the clayey residuum. Lee and Ketelle (1987) discuss pathways of deep groundwater flow on West Chestnut Ridge in greater detail.

\subsection{Soil Role in Hydrologic Discharge and Recharge of Perched and Ground Water Tables}

Rainfall that infiltrates the soil can either move downward to recharge either ephemeral perched water tables or the groundwater table or can. move laterally at shallow depths in permeable zones, where it either surfaces as a wet weather spring or seep or eventually moves downward to the water table. Most landforms underlain by residual soils tend to be recharge areas to the groundwater, but 
some upland residual soils have much higher capacity to recharge groundwater than other soils. For example, residual soils that formed over feldspathic sandstones and siltstones of the uppermost Rome formation have a very high capacity to transmit water very quickly to the groundwater. Many of the Knox Group residual soils also can transmit water quickly downward compared with residual soils underlain by shale; although clay-plugged lower subsoil and upper clay-plugged saprolite slows down the rate. Knox Group 'soils also have the capability to transmit water laterally in $\mathrm{E}$ horizons to lower landforms, a discharge of the ephemeral uppermost perched water table.

Colluvial soils also have the capability to both recharge and discharge water. Laterally transmitted water from colluvial soils is discharged by upwelling in ephemeral "wet weather" seeps or is discharged in seepy wet areas at the bases of hills. Both colluvium and alluvium have a high capacity to move water laterally downslope. Groundwater recharge occurs readily in areas of karst, allowing for rapid movement of rainfall, overland flow; or near-surface lateral flow directly to the watertable through dolines, pipes, or open swallow holes.

The only areas where groundwater is discharged is at permanent springs. The soils downslope from these springs have the gray soil colors typical of soil that is constantly saturated. Stream reaches that flow only during periods of rainfall in which overland flow is generated tend to be areas of groundwater recharge. Stream reaches having permanent flow are areas of discharge.

\subsection{DEPTH TO RESTRICTION}

Depth to a restriction refers to the location in the soil where there is a significant change in porosity or where a lithologic or time discontinuity results in a change in porosity. The potential for perched water conditions, the depth at which perching will occur, and its subsequent lateral downslope movement beneath the soil surface are often controlled by pore-size continuity or discontinuity. Restrictions to water flow are (1) depth to weathered bedrock, (2) subsoil fragipan or fragic properties, (3) pore size discontinuity, and (4) hard rock.

\subsection{DISTURBED SOIL EROSION POTENTIAL}

Soils are rated for erosion of disturbed soils without surface vegetation cover or mulch. Erosion potential is rated from low to very high. Erosion is caused by raindrop splash, which detaches soil particles and overland flow. [See Soil Survey Staff (1983) for rating criteria and classes.] 


\subsection{UNDISTURBED SOIL EROSION POTENTIAL}

Soils are rated for erosion of undisturbed soils that are covered by grass or covered by a forest litter layer. Erosion potential is rated from low to medium in WBW. Soil surface layers that have a high silt and clay content generally have a medium erosion potential, or less than I-2 tons of soil per acre per year. In a forested area, soil particles are brought to the surface above the litter layer by ant and other soil fauna activity and then subjected to downslope transport by overland flow. Increasing slope gradients also affect undisturbed soil erosion potentials.

\subsection{SUITABIUTY FOR PINES}

Soils are rated for their suitability for growing tap-rooted pines. Soil depth for rooting activity is an important rating criterion. Subjective ratings range from poor to good for short-rotation management of pines.

\subsection{RATINGS FOR HARDWOODS}

Soils are rated for long-term management of hardwoods for saw logs. Different species of hardwoods have varying site requirements, including the ability of the soil to supply water and nutrients and potential rooting depth over the life span of the tree. Some hardwoods have the potential to extend their root systems downward deeply into saprolite and to hard rock, where chemical weathering processes release quantities of calcium, potassium, and other elements that trees need for sustained growth. Soils are subjectively rated from poor to good.

\subsection{RATINGS FOR PAVED ROADS AND STREET'S}

Paved roads and streets are covered with an impermeable layer of asphalt or concrete, which covers a prepared subbase of natural soil materials that are modified by the additions of gravel to support a design load. Soils are rated for their suitability as a source of on-site subbase materials and for the ability of the natural undisturbed soil beneath the subbase to support the road and its designed dynamic load.

Ratings range from very poor, for soils with very high silt content or are saturated close to the surface, to good, for soils that have good physical properties and are well drained. Rating criteria are defined in Soil Survey Staff (1988) and were used for generating these interpretive classes. 


\subsection{UNPAVED ROADS}

Unpaved roads are those that rely on the properties of the natural soil for strength. Unpaved roads may be covered with gravel or cinders. Often in construction, the surface organic enriched material is stripped off and the subsoil material from the ditches on either side is put onto the road bed, shaped to crown it, compacted to some extent, and covered with gravel. Therefore, on-site soils are rated for their suitability to support loads. Ditch and roadbank erosion potential is also considered in rating soils for this use. Ratings range from very poor to good. 
. 


\section{CONCLUSIONS}

The soils of WBW were mapped using the most up-to-date knowledge of soil genesis, geologic information, and geomorphic processes that shaped present-day landforms. The extent and distribution of residual soils were used to map the surficial geology and to evaluate spacial lateral geologic variability, primarily distribution of chert throughout all formations of the underlying Knox dolostones, and sandstone in the Mascot formation. Evidence of past geomorphic processes were preserved throughout the watershed by the presence of (1) ancient dark-red clayey alluvium, (2) ancient loamy local alluvium, (3) ancient colluvium (i.e., colluvium without a present-day source), and (4) extensive hillside colluvium of presumed Pleistocene age. Karst Geomorphic processes have also had significant effects on landform evolution in the watershed. Large dolines, surface depressions without open shallowholes, are located at high elevations around the perimeter of the watershed and show minimal evidence of recent subsidence or other activity. The presence of high-silt-content strata separated by cherty slopewash indicates (1) the preservation of dust deposition from the air and (2) slopewash which transported hillside cherty sediments into large, flat-bottomed dolines. Large flatbottomed dolines have also preserved evidence that they contained water for periods of time, possibly during glacial stages of the Pleistocene. The remains of one topographically inverted doline are preserved in the watershed. The only dolines that exhibit effects of present or very-recent-past subsidence are located within present-day drainageways. These particular dolines have the more typical funnel-shaped appearance and do not have flat bottoms. 
. 


\section{REFERENCES}

Arnold, R. W. 1983. Concepts of soils and pedology. IN Wilding, Smeck, and Hall (eds.), Pedogenesis and Soil Taxonomy 1. 'Concepts and interactions. Developments in Soil Science 11A. Elsevier, Amsterdam.

Huggett, R. J. 1975. Soil landscape systems: A model of soil genesis. Geoderma 13: I-22.

Jenny, H. 1941. Factors of Soil Formation. McGraw-Hill, New York. 281 pp.

Ketelle, R. H., and D. D. Huff. 1984. Site characterization of the West Chestnut Ridge Site. ORNUTM-9229.

Lee, S. Y., 0. C. Kopp, and D. A. Lietzke. 1984. Mineralogical characterization of West Chestnut Ridge soils. ORNL/TM-9361.

Lee, S. Y., D. A. Lietzke, R. H. Ketelle, and J. T. Ammons. 1988. Soil and surficial geology guidebook to the Oak Ridge Reservation, Oak Ridge, Tennessee. ORNLTM-10803.

Lietzke, D. A., R. H. Ketelle, and R. R. Lee. 1989. Soils and geomorphology of the East Chestnut Ridge Site. ORNL/TM-11364.

McMaster, W. C. 1963. Geologic map of the Oak Ridge Reservation, Tennessee. ORNL/TM-713.

Moneymaker, R. 1981. Soil Survey of Anderson County, Tennessee. U.S. Government Printing Office, Washington, DC.

Peters, L. N., D. F. Grigal, J. W. Curlin, and W. J. Selvidge. 1970. Walker Branch Watershed Project: Chemical, physical, and morphological properties of the soils of Walker Branch Watershed. ORNL/TM-2968.

Simonson, R. W. 1959. Outline of a generalized theory of soil genesis. Soil Sci. Soc. Am. Proc. 23: 152-I 56.

Smeck, Neil E., E. C. A. Runge, and E. E. Macintosh. 1983. Dynamics and genetic modelling of soil systems. IN Wilding, Smeck, and Hall (eds.), Pedogenesis and Soil Taxonomy 1 . Concepts and Interactions. Developments in Soil Science $11 \mathrm{~A}$. Elsevier, Amsterdam. 
Smith, G. D. 1983. Historical development of soil taxonomy. IN Wilding, Smeck, and Hall (eds.), Pedogenesis and Soil Taxonomy 1. Concepts and Interactions. Developments in Soil Science 1 IA. Elsevier, Amsterdam.

Soil Survey Staff. 1975. Soil taxonomy: A basic system of soil classification for making and interpreting soil surveys. Agriculture Handbook No. 436. U.S. Department of Agriculture, U.S. Government Printing Office, Washington, D.C.

Soil Survey Staff. 1983. National soils handbook. USDA-SCS Agriculture Handbook No. 430-VI-NSH. U.S. Government Printing Office, Washington, D.C.

Soil Survey Staff. 1984. Soil survey manual, rev. USDA-SCS Agriculture Handbook 430-V-SSM. U.S. Government Printing Office, Washington, D.C. 


\section{APPENDIX A}

\section{AI SOIL CLASSIFICATION}

Each soil has distinctive subset of morphologic properties that can include color, horizonation, soil structure, and soil texture. Some related properties are measured in the laboratory. Important diagnostic properties that soils have in common and that were produced by a soil-forming process (i.e., soil genesis) are used to define conceptual classes for purposes of classifying soils (Smith 1983). in the United States, a hierarchical system of soil classification evolved to its current state with the development of the handbook Soil Taxonomy (Soil Survey Staff 1975), along with more recent amendments that are a reflection of advancing knowledge of soil science and soil genesis. Soil Taxonomy is based primarily on the properties of soil near the surface (i.e., properties that are the most direct result of a soil-forming process), but some deeper soil properties (at or near a depth of $2.0 \mathrm{~m}$ ) are used to define one or more high-level categories of the classification system. The highest category of Soil Taxonomy is the "order." There are currently eleven orders. The WBW area has soils in four of the ten orders. These orders are:

1. Entisols. Entisols in WBW are very young, well to poorly drained soils of floodplains that have a thin A horizon over stratified alluvium.

2. Inceptisols. Soils with weakly developed genetic soil horizons are classified into this order. Most of these soils are on low terraces or on floodplains where there is little if any deposition.

3. Affisols. Soils in this order have a clay enriched subsoil Bt horizon (argillic horizon) and more than 35\% base saturation at a depth of 1.8 to 2.0 meters.

4. Ultisols. Soils in this order have a clay enriched subsoil Bt horizon' (argillic horizon) but are highly weathered and very acidic with less than $35 \%$ base saturation at a depth of 1.8 to 2.0 meters below the surface.

All of the soils in an order must have at least one or more common properties that are the result of a common genetic pathway of soil formation.

Each order has one or more suborders. Suborder soils have 'more properties in common. In the order Entisols, there are two suborders present in WBW. These are (1) Fluvents, well- and moderately well-drained soils of floodplains that have fine stratification throughout the upper soil and (2) Aquents, wet soils of floodplains and seepage areas. There is one suborder to Ochrepts in the Inceptosol order. Ochrepts have a thin, light-colored surface horizon and a subsoil cambic horizon with minimal soil formation (i.e., a horizon where geologic rock structure has been 
destroyed by the formation of stable soil structure). Within the watershed, there is one suborder of Udalfs in the order of Alfisols. Udalfs are freely drained and well-oxidized soils. Within the watershed there are two suborders of Ultisols. The suborder of Aquults includes wet soils that have a light-colored surface layer (ochric epipedon) and a clay-enriched subsoil horizon (argillic horizon). The suborder of Udults, includes well-drained soils that have both an ochric epipedon and an oxidized subsoil argillic horizon. Udults comprise the soils of greatest extent in WBW.

Each suborder has one or more "great groups," with the soils in each great group having still more commonality of properties. Each great group has one or more "subgroups," and each subgroup has one or more 'families." Every category above. the family is conceptual. The family category is represented by real physical, chemical, and mineralogical properties derived from a prescribed depth and thickness of soil. In the WBW area, mineralogy classes are similar for most soils (either kaolinitic, mixed or siliceous), whereas particle-size classes range from loamy-skeletal to fine-loamy to fine-silty to clayey to clay-skeletal. The "soil series" is the lowest conceptual category. Each soil series is mostly defined by observable soil features. Some of the soils in the WBW area would fit into existing soil series, provided only the upper soil, above a depth of $2 \mathrm{~m}$ (or to rock if shallower), were classified. Appendix A-3 lists soil series names from the 1967 WBW soil survey with a comparison with soil series from this soil survey.

\section{A.2 SOIL DESCRIPTIONS}

The following soil profile descriptions were described from pits or trenches. Each profile description represents a fairly typical example of a pedon.

\section{KNOX SOILS}

Soil Series No. 400

Location:

Classification: Geomorphic Position: Slope and Aspect: Parent Material(s): Vegetation: Described By: Date:
East Chestnut Ridge, Doline A sideslope trench in upper northeast corner of site. E60950, N27650

Typic Paleudults (Hapludults); clayey, kaolinitic, thermic.

Doline sideslope

25 to $30 \%$ SW

Copper Ridge residuum

Pines, hardwoods, and cedars of old field succession

Lietzke

May 30, 1989 
Soil Description

O 3 to $0 \mathrm{~cm}$; leaf litter and twigs.

A 0 to $7 \mathrm{~cm}$; dark brown (1 OYR $3 / 3$ ) extremely cherty silt loam; strong fine granular structure; very friable; many fine and common medium roots; 50 to $60 \%$ chert fragments; clear wavy boundary.

Ap 7 to $25 \mathrm{~cm}$; dark yellowish brown (10YR 4/4) extremely cherty silt loam; moderate fine granular structure; very friable; common fine and medium roots; 50 to $60 \%$ chert fragments; gradual wavy boundary. (Base of surficial creep materials.)

E/B 25 to $40 \mathrm{~cm}$ : yellowish brown (10YR 5/4) E part and strong brown (7.5YR 5/6) B part; extremely cherty silt loam; weak fine subangular blocky structure; very friable; few fine and medium roots; 60 to $70 \%$ fragments; gradual irregular boundary.

B/E 40 to $64 \mathrm{~cm}$ : yellowish red (5YR 5/6) B part and strong brown (7.5YR 5/6) E part; extremely cherty silty clay loam; weak medium subangular blocky structure; very friable; few fine roots; 50 to $60 \%$ fragments; gradual irregular boundary.

Btl 64 to $86 \mathrm{~cm}$ : red (2.5YR 4/8) cherty clay; moderate medium subangular blocky structure: firm: yellowish red (5YR 5/6) clay on ped surfaces; yellowish and reddish saprolite colors within ped interiors in lower part; few fine roots; 15 to $25 \%$ fragments; gradual wavy boundary.

Bt2 86 to, $130 \mathrm{~cm}$; highly mottled red (2.5YR 4/8), yellowish red (5YR 5/6) brownish yellow (10YR 6/8) cherty clay; weak medium subangular blocky structure; firm; yellowish red (5YR 5/6) clay on ped surfaces; few fine roots; 20 to $30 \%$ fragments; gradual wavy boundary.

BC 130 to $150 \mathrm{~cm}$; yellowish red (5YR 5/6) and brownish yellow (10YR 6/8) saprolitic material that easily crushes to cherty clay; weak coarse subangular blocky structure, but ped interiors are saprolite; very firm; thick red (2.5YR 4/6) clay of surfaces; few fine roots; 15 to $20 \%$ chert fragments.

NOTES: The Copper Ridge residual soils in this trench, about $30 \mathrm{~m}$ long, and on slopes of 25 to $30 \%$ are borderline Hapludults-Paleudults based on soil morphology.

Soil Series No. 401

Location:

Classification:

Geomorphic Position:

Slope and Aspect:

ORR. Chestnut Ridge area of Roane County, and about 200 feet north of boundary of borrow area and southwest of depression. E33500, N28100

Typic Paleudults; clayey, mixed, thermic

Upper sideslope

25 to $28 \%$ north-northwest 
Parent Material(s):

Vegetation:

Described By:

Date:

Copper Ridge residuum

Hardwoods of old field succession

Lietzke

May 18, 1988

\section{Soil Description}

Oi 4 to $0 \mathrm{~cm}$; leaf litter.

A $\quad 0$ to $12 \mathrm{~cm}$; dark brown (1 OYR $3 / 3$ ) cherty silt loam; moderate fine granular structure; very friable; many fine and medium roots; many pores; 15 to $20 \%$ chert fragments; clear wavy boundary.

E $\quad 12$ to $33 \mathrm{~cm}$; yellowish brown (1 OYR 5/4) cherty silt loam; weak fine granular structure; very friable; common fine and medium roots; many pores; 25 to $35 \%$ chert fragments; clear wavy boundary.

E/B 33 to $53 \mathrm{~cm}$; dark yellowish brown (1 OYR 4/6) cherty silt loam E part and strong brown (7.5YR 5/6) cherty silty clay loam B part; weak medium subangular blocky structure; very friable; few fine and medium roots; many pores; 20 to $35 \%$ chert fragments; gradual wavy boundary.

B/E 53 to $75 \mathrm{~cm}$; yellowish red (5YR 5/6) B part and strong brown (7.5YR 5/6) E part; cherty silty clay loam; moderate medium subangular blocky structure; friable; few fine and medium roots; many pores; 30 to $35 \%$ chert fragments; gradual wavy boundary.

Btl $\quad 75$ to $100 \mathrm{~cm}$; red (2.5YR 4/8) cherty clay; moderate medium subangular blocky structure; firm; ped faces are yellowish red (5YR 5/6) with no evidence of clay flows; few fine and medium roots; 20 to $25 \%$ chert fragments; gradual wavy boundary.

Bt2 100 to $116 \mathrm{~cm}$; red (2.5YR 4/8) cherty clay; moderate medium subangular blocky structure; very firm; yellow (2.6Y 7/8) saprolite colors; thick yellowish red (5YR 5/6) clay flows on ped faces; few medium and fine roots; many pores.

NOTES: Large chert fragments prevented further auger penetration. Pit dug to $75 \mathrm{~cm}$ depth. This is an included soil in No. 400 map unit delineations. It occurs on steep north and east facing slopes.

Soil Series No. 402

Location':'

Classification:

Physiography:

Geomorphic Position:
ORR. Telephone ROW transect across Chestnut Ridge. Second pit north of gasline road and telephone line intersection. E29900, N26300

Typic Hapludults; clayey,.mixed, thermic Upland Mid sideslope 
Slope and Aspect:

Parent Material(s):

Vegetation:

Described By:

Sampled By:

Date:
25 to $45 \%$ WNW

Chepultepec residuum

Chestnut oak, red oak, and white oak

Lietzke

Lietzke, Ammons, and Timpson

March 23, 1988

Soil Description

Oi 5 to $0 \mathrm{~cm}$; leaf litter and root mat.

El $\quad 0$ to $17 \mathrm{~cm}$; pale olive (5Y 6/3) cherty loam: weak fine granular structure; very friable; many fine and medium roots; many pores; 15 to $25 \%$ chert fragments; gradual wavy boundary.

E/B 17 to $40 \mathrm{~cm}$; olive yellow (2.5Y 6/6) E part and yellowish brown (10YR 5/6) B part; cherty loam; weak fine granular structure; very friable; many fine and medium roots; many pores; 15 to $25 \%$ chert fragments; gradual wavy boundary. (Lower boundary contains B/E horizon.)

Btl 40 to $69 \mathrm{~cm}$; yellowish red (5YR 5/8) clay or clay loam; moderate fine subangular blocky structure; friable; common medium and fine roots; many pores; 5 to $10 \%$ chert fragments; gradual wavy boundary.

Bt2 69 to $99 \mathrm{~cm}$; yellowish red (5YR 5/8) with red (2.5YR 4/8) and yellowish brown (1 OYR 5/6) saprolite colors; clay or clay loam; moderate fine subangular blocky structure; firm; yellowish red (5YR 5/8) clay films on all ped faces; common medium and fine roots; many pores; 5 to $10 \%$ chert fragments; gradual wavy boundary.

BC 99 to $139 \mathrm{~cm}$; brownish yellow (10YR 6/6) and red (2.5YR 4/8) saprolite colors; clay or clay loam: weak coarse subangular and angular blocky structure; very firm: red (2.5YR 4/8) clay films on many ped faces and coating large pores; few fine roots; many pores; 5 to 10\% chert fragments; gradual wavy boundary.

CB 139 to $187 \mathrm{~cm}$ : yellowish brown (10YR 5/8) saprolite that easily crushes to silty clay loam; angular blocks from fractured saprolite; very firm; strong brown (7.5YR 5/6) clay flows on most faces: water flow zones with light gray (1 OYR 7/1) interiors and olive yellow (2.5Y 6/8) exteriors; few fine roots; many pores:' clear wavy boundary.

Cl 187 to $231 \mathrm{~cm}$; strong brown (7.5YR 5/6) and brownish yellow (10YR 6/8) saprolite that easily crushes to silty clay loam; angular blocks from fractured saproliie; very firm; yellowish red (5YR 5/8) clay flows on some faces; red (2.5YR 4/8) iron plasma in pores and coating some faces; few fine roots; many pores; (Manganese concentrate zone marks base of horizon.) 
C2 231 to $276 \mathrm{~cm}$; yellowish red (5YR 5/6) and brownish yellow (10YR 6/8) multi-colored saprolite with thin strata of disoriented highly weathered grayish and reddish very fine grained sandstone that crushes to silty clay loam; very firm; water flow zones have light gray (10YR 7/2) interiors and yellowish iron depleted exteriors: few fine roots; common to many manganese concentrate bodies; less than $5 \%$ chert fragments.

Soil Series No. 403

Location:

Classification: Geomorphic Position: Slope and Aspect: Parent Material(s): Vegetation: Described By: Date:
East Chestnut Ridge site in long trench that crosses the Chepultepec-Longview and Longview-Kingsport boundaries. E61050, N26450

Typic Hapludults; clayey-skeletal, kaolinitic, thermic Summit shoulder and upper sideslope

15 to $18 \%$ SE Longview residuum, uppermost part of the section Hardwoods Lietzke May 30, 1989

\section{Soil Description}

03 to $0 \mathrm{~cm}$; leaf litter and root mat.

A $\quad 0$ to $10 \mathrm{~cm}$; very dark grayish brown (1 OYR $3 / 2$ ) very cherty silt loam; strong fine granular structure; very friable; many fine and common medium roots; 45 to $50 \%$ chert fragments; clear wavy boundary.

E $\quad 10$ to $27 \mathrm{~cm}$; light yellowish brown (10YR 6/4) very cherty silt loam: weak fine granular structure; very friable; many fine and common medium roots; 45 to $50 \%$ chert fragments; clear wavy boundary.

B/E 27 to $37 \mathrm{~cm}$; strong brown (7.5YR 5/6) B part, and yellowish brown (10YR 5/6) E part; very cherty silty clay loam; weak fine subangular blocky structure: very friable; few fine and medium roots; 35 to $40 \%$ fragments; clear wavy boundary.

Btl 37 to $56 \mathrm{~cm}$; red (2.5YR 4/8) cherty to very cherty clay; moderate medium subangular blocky structure; friable; few fine and medium roots; 30 to $40 \%$ fragments; gradual wavy boundary.

Bt2 56 to $77 \mathrm{~cm}$; mottled red (2.5YR 4/8) and yellowish red (5YR 5/6) very cherty clay; moderate medium subangular blocky structure; firm; some yellowish brown (10YR 5/6) saprolite bodies in ped interiors; strong brown (7.5YR 5/6) clay on ped surfaces; few fine roots; 30 to $40 \%$ fragments; gradual wavy boundary. 
Bt3 77 to $110 \mathrm{~cm}$; distinctly mottled yellowish brown (10YR 5/6) and yellowish red (5YR 5/6) very cherty clay with some red (2.5YR 4/8) streaks; moderate fine subangular blocky structure; firm; strong brown (7.5YR 5/6) clay on ped surfaces; 35 to $45 \%$ chert fragments; gradual wavy boundary.

BC 110 to $135 \mathrm{~cm}$; prominently mottled red (2.5YR 4/8), brownish yellow (1 OYR $6 / 6)$, and olive yellow (2.5Y 6/6) very cherty clay; weak fine subangular blocky structure; firm; yellowish red (5YR 5/6) clay on ped surfaces; no roots; 35 to $45 \%$ fragments. (Upper clay-plugged saprolite.)

Soil Series No. 404

Location:

Classification:

Geomorphic Position:

Slope and Aspect:

Parent Material(s):

Vegetation:

Described By:

Date:
East Chestnut Ridge. Trench in open field. E58500, N25550

Typic Hapludults; clayey, mixed, thermic

Broad ridgetop bench

4 to $5 \%$ SE

Lowermost Mascot residuum

Grass and weeds

Lietzke

May 23, 1989

Soil Description

Ap 0 to $20 \mathrm{~cm}$; dark brown (10YR 3/3) cherty loam; moderate fine granular structure; friable; many fine roots; 20 to $25 \%$ chert fragments; abrupt wavy boundary.

Btl 20 to $36 \mathrm{~cm}$; strong brown (7.5YR 4/6) cherty clay loam; weak fine subangular blocky structure: friable; common fine roots; 15 to $20 \%$ chert fragments; clear wavy boundary.

Bt2 36 to $68 \mathrm{~cm}$ : red (2.5YR 4/8) clay; moderate fine and medium subangular blocky structure; firm; red (2.5YR 4/6) clay films on ped faces; 10 to $15 \%$ chert fragments; gradual wavy boundary.

Bt3 68 to $117 \mathrm{~cm}$; mottled red (2.5YR 4/8) and yellowish red (5YR 5/6) clay; moderate fine angular blocky structure; very firm; yellowish red (5YR 4/6) clay films on ped faces; some saprolite remnants in ped interiors; few fine roots; 5 to $10 \%$ chert fragments; gradual wavy boundary.

BC 117 to $145 \mathrm{~cm}$; prominent1y mottled red (2.5YR 4/8), brownish yellow (1 OYR 6/8) and yellowish red (EYR 5/6) clay; moderate fine angular blocky structure: very firm; clay plugged; few fine roots: 5 to 10\% chert fragments; gradual irregular boundary.

CB 145 to $185 \mathrm{~cm}$; swirled brown (1 OYR 4/3), yellowish red (5YR 4/6), strong brown (7.5YR 5/6) and brownish yellow (1 OYR 6/8) saprolitic material that easily crushes to clay; very firm (augered). 
C $\quad 185$ to $263 \mathrm{~cm}$; multi-colored saprolite that is dominated by reds in the upper part and yellows in the lower part; black manganese coatings on some cracks. (Hit chert fragment at $263 \mathrm{~cm}$.)

NOTES: Enough chert matrix sandstone occurs so that the surface of these soils commonly has a loam and sometimes a fine sandy loam texture.

Soil Series No. 405

Location:

Southeast corner of Walker Branch Watershed above

Classification:

Geomorphic Position:

weirs. Approx. 75' N of grid point 7582, 5546

Typic Hapludalfs; fine, mixed, thermic

Slope and Aspect:

Parent Material(s):

Vegetation:

Described By:

Date: Uppermost bench of bench landform segments on steep sideslope

35 to $40 \%$ NW

Mascot residuum

Hardwoods

Lietzke

May 22, 1989

\section{Soil Description}

03 to $0 \mathrm{~cm}$; leaf litter.

A $\quad 0$ to $11 \mathrm{~cm}$; very dark grayish brown (1 OYR 3/2) extremely cherty silt loam; moderate fine granular structure; very friable; many fine and few medium roots; 75 to $85 \%$ chert lag from slopes above; clear wavy boundary.

E $\quad 11$ to $20 \mathrm{~cm}$; yellowish brown (1 OYR 5/4) very cherty silt loam; weak fine granular structure; very friable; common fine and few medium roots; 50 to $75 \%$ lag chert; clear wavy boundary.

Btl 20 to $45 \mathrm{~cm}$; red (2.5YR 4/8) clay: moderate medium and coarse subangular blocky structure; firm; continuous yellowish red (5YR 4/6) clay flows on ped surfaces; common fine and medium roots; 10 to $15 \%$ fragments; gradual wavy boundary.

Bt2 45 to $75 \mathrm{~cm}$ : red (2.5YR 4/6) clay; moderate medium and coarse subangular and angular blocky structure: very firm; continuous red (2.5YR $4 / 8$ ) clay flows on ped surfaces; few fine and medium roots; 10 to $15 \%$ fragments; clear irregular boundary.

BC 75 to $86 \mathrm{~cm}$; light yellowish brown (10YR 6/4) chert seam and sandstone that crushes to sandy loam; massive; sand strata saturated; few fine and medium roots; abrupt wavy boundary. 
CB 86 to $140 \mathrm{~cm}$; red (2.5YR 4/6) clay; fine angular blocks brachiated?; friable; thin dark reddish brown (2.5YR 3/4) strata: some thin strata fragments are coated with iron-manganese oxides; few fine roots; 1 to $5 \%$ fragments; clear irregular boundary.

C $\quad 140$ to $148 \mathrm{~cm}$ : pinkish gray (7.5YR 7/2) and red (2.5YR 4/8) soft saprolite; massive.

R $148 \mathrm{~cm}$; carbonate rock contact.

NOTES: Removed large chert fragment with slickensides on surface, which indicates that the rock may have been brachiated. Removed small unattached dolomite ledge from right side of pit at a depth of $50 \mathrm{~cm}$. Depth to rock on other side of pit was $150 \mathrm{~cm}$.

Soil Series No. 406

Location:

Classification:

Geomorphic Position:

Slope and Aspect:

Parent Material(s):

Vegetation:

Described By:

Date:
East Chestnut Ridge. E58730, N26050

Typic Hapludults; clayey, kaolinitic, thermic

Ridgetop bench landform

3-4\% SE

Kingsport residuum

Hardwoods

Lietzke in lineament trench

May 23, 1989

Soil Description

$0 \quad 2$ to $0 \mathrm{~cm}$; leaf litter and some grass.

A 0 to $4 \mathrm{~cm}$; very dark grayish brown (10YR 3/2) cherty silt loam; strong fine granular structure; very friable: many fine roots; 15 to $20 \%$ chert fragments; abrupt wavy boundary.

E $\quad 4$ to $16 \mathrm{~cm}$; pale olive (5Y 6/4) cherty silt loam; moderate fine granular structure; very friable; many fine roots; 15 to $20 \%$ chert fragments: clear wavy boundary.

EB 16 to $28 \mathrm{~cm}$; strong brown (7.5YR 5/8) cherty silty clay loam; weak fine subangular blocky structure; very friable; common fine roots; 15 to $20 \%$ chert fragments: clear wavy boundary.

Btl 28 to $48 \mathrm{~cm}$; yellowish red (5YR 518) clay; moderate fine subangular blocky structure; friable; strong brown (7.5YR 5/6) clay films on most ped faces; common fine roots; 5 to $10 \%$ chert fragments; gradual wavy boundary. 
Bt2 48 to $75 \mathrm{~cm}$; mottled red (2.5YR 4/8) and strong brown (7.5YR 5/6) clay; moderate fine angular blocky structure; firm; red (2.5YR 4/8) clay films on most ped faces; light gray (10YR 7/2) streaks due to perching of water; remnant saprolite colores in some ped interiors in the lower part; few fine roots; 5 to $10 \%$ chert fragments; gradual wavy boundary.

BC 75 to $135 \mathrm{~cm}$; highly mottled saprolitic and drainage colors of reds, yellow browns and light grays; clay; moderate fine angular blocky structure; very firm; brown (7.5YR 5/4) clay films on most ped faces; few fine roots; 5 to $10 \%$ chert fragments; most ped interiors are saprolite; gradual irregular boundary.

CB 135 to $150 \mathrm{~cm}$; multi-hued reddish and yellowish very soft saprolitic material that easily crushes to clay, but there are distinct strata that are silt loam or silty clay loam; friable; massive rock controlled structure.

NOTES: Depth to the CB horizon ranges from 75 to $140 \mathrm{~cm}$ in the trench.

Soil Series No. 407

Location:

Classification:

Geomorphic Position: Slope and Aspect: Parent Material(s):

Vegetation:

Described By:

Date:
Walker Branch Watershed. About 50' grid south of 6074-6790 grid stake in recent tipover Typic Hapludults; clayey or clayey-skeletal, kaolinitic, thermic

Steep sideslope above main channel of west fork $40 \%$ WSW

Surficial creep and residuum of Kingsport, 1-2\% outcrops in delineation

Forest

Lietzke

January 11, 1990

\section{Soil Description}

Oi \& Oe 4 to $0 \mathrm{~cm}$; oak leaves.

Oa-A 0 to $1 \mathrm{~cm}$; black (1OYR 2/1) extremely cherty silt loam; moderate fine granular structure; very friable; more than $70 \%$ chert fragments; many fine and few medium roots; abrupt wavy boundary.

El 1 to $28 \mathrm{~cm}$; light brownish gray (2.5Y 6/2) extremely cherty silt loam; weak fine granular structure; very friable; slightly sticky; $60-70 \%$ chert fragments; many fine and common medium roots; gradual wavy boundary.

E2 28 to $41 \mathrm{~cm}$; light yellowish brown (2.5Y 6/4) extremely cherty silty clay loam; weak fine subangular blocky structure; very friable; sticky; 50-65\% chert fragments; few fine roots; few medium roots; few coarse roots; clear irregular boundary. 
E/B 41 to $56 \mathrm{~cm}$; light yellowish brown (2.5Y 6/4) extremely cherty silt loam E part, and strong brown (7.5YR 5/6) extremely cherty silty clay loam B part; weak medium subangular blocky structure; very friable; sticky; $45-55 \%$ chert fragments; few fine roots; few medium roots; clear irregular boundary. (Boundary includes thin B/E horizon.) Base of saturated soil.

Bt $\quad 56$ to $79 \mathrm{~cm}$; red (2.5YR 4/8) with streaks and ped coatings of yellowish red (5YR 5/6) and strong brown (7.5YR 5/6) cherty clay; moderate fine and medium subangular blocky structure; friable; 20 to $25 \%$ chert fragments; few fine and few medium roots; abrupt irregular boundary. (Chert fragments become oriented with respect to strike and dip at base of horizon.)

BC 79 to $120 \mathrm{~cm}$; highly mottled red (2.5YR 4/8), yellowish red (5YR 5/8), strong brown (7.5YR 5/6) and yellowish brown (10YR 5/8) clay plugged saprolitic material that very easily crushes to cherty clay; massive; firm; red (2.5YR 4/6) clay flows in pores and cracks; black Mn-Fe zones; $15-25 \%$ highly weathered gravel sized chert fragments; few medium roots; diffuse irregular boundary.

CB 120 to $170 \mathrm{~cm}$; saprolitic strata of red (2.5YR 4/8) clay, brownish yellow (10 YR 6/8) silty clay loam, and yellow (1 OYR 7/6-7/8) silt loam; massive; clay plugged with red (2.5YR 4/8) clay flows; black Mn-Fe coatings; common highly weathered otitic and relatively less weathered chalcedaneous chert fragments.

NOTES: Pit dug to 50 inches, augered rest of way to 67 inches and large chert fragment. This delineation has an cave opening.

Soil Series No. 408

Location:

Walker Branch Watershed above old road that goes down from subsurface transport research site. Along grid line 7130 . East about 100 feet between grid point 7130,5470 , and grid point 7130,5734 , then about 60 feet grid north.

Classification:

Geomorphic Position:

Slope and Aspect:

Parent Material(s):

Typic Hapludults; loamy-skeletal, siliceous, thermic

Steep dip slope

$30 \%$ SSW

Chepultepec chert beds with $30 \mathrm{~cm}$ of surficial cherty

Vegetation:

Described By:

creep

Hardwoods

Date:

Lietzke

May 2, 1989 
Soil Description

04 to $0 \mathrm{~cm}$; oak leaf litter.

Al 0 to $5 \mathrm{~cm}$; very dark brown (10YR $2 / 2$ ) cherty silt loam; strong fine granular structure; very friable; many fine roots; 15 to $20 \%$ chert fragments; clear wavy boundary.

A2 5 to $16 \mathrm{~cm}$; dark brown (1 OYR $3 / 3$ ) cherty silt loam; strong fine granular structure; very friable; many fine roots; 20 to $50 \%$ chert fragments: clear wavy boundary.

E $\quad 16$ to $40 \mathrm{~cm}$; yellowish brown (1 OYR 5/4) extremely cherty silt loam; weak fine granular structure; very friable to loose; organic matter streaming downward; common fine and medium roots: 50 to $70 \%$ chert fragments; gradual irregular boundary.

E/B 40 to $61 \mathrm{~cm}$; light yellowish brown (10YR 6/4) E part, and yellowish brown (10YR 5/4) B part, extremely cherty silt loam; weak medium subangular blocky structure; very friable to loose; few brown (7.5YR 4/4) clay bridges; few fine and medium roots; 70 to $80 \%$ chert fragments; gradual irregular boundary.

B/E 61 to $90 \mathrm{~cm}$; yellowish brown (10YR 5/6) extremely cherty silty clay loam B part, and pale brown (1 OYR 6/3) extremely cherty silt loam E part; weak coarse subangular blocky structure; friable to firm; few strong brown (7.5YR 4/6) clay bridges and clay coatings on fragments; few fine and medium roots; 70 to $75 \%$ chert fragments; gradual irregular boundary.

Bt 90 to $114 \mathrm{~cm}$; yellowish brown (10YR 5/6) and brownish yellow (10YR 6/6) extremely cherty silty clay loam; weak coarse subangular blocky structure; very porous; firm to very firm; yellowish red (5YR 5/6) clay coats on fragments, as bridges, and as filaments; few fine roots; 60 to $70 \%$ fragments; gradual irregular boundary. (Base of chert bed.)

BC 114 to $150 \mathrm{~cm}$; mottled yellowish brown (1 OYR 5/6) and brownish yellow (1 OYR 6/6) very cherty to extremely cherty clay; weak coarse subangular blocky structure tending towards massive; very firm; yellowish red (5YR 5/6) clay coats on fragments, as bridges, and asfilaments; few fine roots: 50 to $60 \%$ fragnents; gradual irregular boundary. (Partially transformed saprolite..)

CB 150 to $176 \mathrm{~cm}$ : mottled yellowish brown, brownish yellow, yellowish red and red very cherty clay, with light gray (10YR 7/1) in flow zones; some saprolitic areas are light gray (10YR 7/2) but cracks are coated with brownish yellow (1 OYR 6/6) clay.

NOTES: Estimated permeability is rapid to $70 \mathrm{~cm}$, moderate to $130 \mathrm{~cm}$, and slow below. 


\section{KNOX COLUVIUM}

Soil Series No. 430

Location:

Classification:

Physiography: Geomorphic Position: Slope and Aspect: Parent Material(s): Vegetation: Described By: Date:
Roane County. ORR West Chestnut site. E18900, N25950

Fragic Paleudults; fine-loamy or loamy-skeletal, siliceous, thermic

Upland

Doubly concave lower footslope

$4 \%$ SE

Younger colluvium over older colluvium

Pines and hardwoods

Lietzke

December 5, 1983

Soil Description

$0 \quad 4$ to $0 \mathrm{~cm}$; leaves, needles and twigs.

E 0 to $15 \mathrm{~cm}$; dark grayish brown (1 OYR 4/2) gravelly loam; moderate fine granular structure; very friable; many fine and medium roots; 15 to $30 \%$ chert fragments; clear wavy boundary.

Btl $\quad 15$ to $39 \mathrm{~cm}$; yellowish brown (1 OYR 5/4) gravelly to very gravelly clay loam; moderate fine to medium subangular blocky structure; friable; thin dark yellowish brown (1 OYR 4/4) clay films on ped faces; few medium roots; 25 to $50 \%$ chert fragments; gradual wavy boundary.

Bt2 39 to $60 \mathrm{~cm}$ : brown (7.5YR 4/4) gravelly clay loam; moderate medium subangular blocky structure; friable; thin yellowish red (5YR 4/6) clay films on ped faces; some ped faces coated with black manganese materials; few medium roots; 20 to $35 \%$ chert fragments; gradual wavy boundary.

2Btx/Ex 60 to $115 \mathrm{~cm}$; yellowish red (5YR 4/6) -B part, and light yellowish brown (10YR 6/4) -E part; gravelly clay loam; weak coarse prismatic structure; 30 to $40 \%$ brittle zones mostly associated with Ex, remainder is friable to firm; reddish brown (5YR 4/4) coats both primary and secondary ped faces, pores and roots channels; many vesicular pores in brittle parts; few roots on prism faces and in friable material; 25 to $30 \%$ chert fragments; gradual irregular boundary.

2Bt 115 to $150 \mathrm{~cm}$; strong brown (7.5YR 5/6) gravelly loam; weak coarse subangular blocky structure; friable; thin red (2.5YR 4/6) clay films on ped faces: many light yellowish brown (10YR 6/4) flow zone streaks descending from the $\mathrm{E}$ materials in the horizon above; no roots; 10 to $20 \%$ chert fragments.

NOTES: Fluctuating water rises to about $90 \mathrm{~cm}$ below the surface or less during rainy periods when soil water is moving laterally. Some ares within the mapping dellineatlon are saturated at the surface for several days during late winter. 
Soil Series No. 431

Location:

Classification:

Geomorphic Position:

Slope and Aspect:

Parent Material(s):

Vegetation:

Described By:

Date:
East Chestnut Ridge Site, Doline A. E60850, N27850 Fluventic Dystrochrepts; fine-loamy, siliceous, thermic Doline bottom

$1-2 \%$

Modern agricultural sediments overlying an older paleosol

Hardwoods

Lietzke

July 12, 1989

\section{Soil Description}

A $\quad 0$ to $23 \mathrm{~cm}$ : dark brown (7.5YR 3/2) very cherty silt loam slope wash; moderate fine granular structure; very friable; common fine and common medium roots; 30 to $40 \%$ chert fragments; clear wavy boundary.

C $\quad 23$ to $98 \mathrm{~cm}$; dark brown (7.5YR 3/3) loam; massive; stratified; friable; thin strata and bits of red silty clay loam scattered throughout; charcoal fragments scattered throughout; few fine and medium roots; 5 to $10 \%$ chert fragments; clear wavy boundary.

$\mathrm{Ab} \quad 98$ to $140 \mathrm{~cm}$; dark brown (7.5YR 3/2) silt loam; strong fine granular structure; very friable; few fine roots; less than $10 \%$ chert fragments; high amount of charcoal fragments in upper part; gradual wavy boundary.

Bw $\quad 140$ to $190 \mathrm{~cm}$ : dark brown (7.5YR 3/4) silt loam; weak fine subangular blocky structure; friable; few fine roots; less than 10\% chert fragments; clear wavy boundary.

2Bt 190 to $235 \mathrm{~cm}$; strong brown (7.5YR 4/6) heavy silt loam; friable; 10 to $15 \%$ chert fragments. (augered)

$3 \mathrm{Bt} \quad 235$ to $260 \mathrm{~cm}$; yellowish red (5YR $5 / 8$ ) cherty silty clay loam; 15 to $25 \%$ chert fragments. (augered)

Soil No. 433

Location:

Classification:

Geomorphic Position:

Slope and Aspect:

Parent Materials:

Vegetation:

Described By:
Walker Branch Watershed. Pit No 11 from TM 2968. pages 67 to 71

Typic (Humic) Paleudults, fine-loamy or loamy-skeletal, siliceous, thermic

Steep sideslopes with easterly aspects

25 to $45 \%$ E

Colluvium over residuum

Old field succession hardwoods

R. Moneymaker, modified by Lietzke 


\section{Soil Description}

02 to $0 \mathrm{~cm}$; hardwood litter, the lower part partially decomposed.

Al 0 to $5 \mathrm{~cm}$; dark brown (7.5YR 3/2) cherty silt loam; strong medium granular structure; friable; abrupt smooth boundary; $27 \%$ sand, $7 \%$ clay, $66 \%$ silt, $19 \%$ frags., $34 \%$ base sat.

A2 5 to $23 \mathrm{~cm}$; dark brown (7.5YR 4/2) cherty silt loam: weak medium granular structure; friable; clear smooth boundary; $26 \%$ sand, $7 \%$ clay, $67 \%$ silt, $20 \%$ frags., $55 \%$ base sat.

Btl $\quad 23$ to $38 \mathrm{~cm}$; strong brown (7.5YR 5/6) cherty silt loam; weak medium subangular blocky structure: friable; patchy clay films; clear smooth boundary; $22 \%$ sand, $12 \%$ clay, $66 \%$ silt, $17 \%$ frags., $29 \%$ base sat.

Bt2 38 to $60 \mathrm{~cm}$; strong brown (7.5YR 5/6) cherty silt loam: moderate fine and medium subangular blocky structure; friable; common clay films; clear smooth boundary; $18 \%$ sand, $20 \%$ clay, $63 \%$ silt, $23 \%$ frags., $71 \%$ base sat.

2Bt3 60 to $80 \mathrm{~cm}$; yellowish red (5YR 4/8) cherty silt loam; moderate medium subangular blocky structure; firm; patchy clay films; gradual smooth boundary. $18 \%$ and, $17 \%$ clay, $65 \%$ silt, $22 \%$ frags., $58 \%$ base sat.

2Bt4 80 to $110 \mathrm{~cm}$; yellowish red (5YR 4/8) cherty silt loam; strong medium subangular blocky structure; firm; patchy clay films; $19 \%$ sand, $20 \%$ clay, $61 \%$ silt, $34 \%$ frags., $27 \%$ base sat.

Soil Series No. 434

Location:

Classification:

Geomorphic Position:

Slope and Aspect:

Parent Materials:

Vegetation:

Described By:
Walker Branch Watershed. Pit No. 3 from TM-2968, pages 25 to 28

Typic Paleudults; fine-loamy, siliceous, thermic

Linear to slightly convex sideslopes

15 to $25 \%$ SW

Colluvium over residuum

Hardwoods

R. Moneymaker, modified by Lietzke

Soil Description

03 to $0 \mathrm{~cm}$; hardwood litter, the lower part partially decomposed.

El 0 to $5 \mathrm{~cm}$; grayish brown (1 OYR 512) cherty silt loam; weak fine granular structure; friable; clear smooth boundary; $41 \%$ sand, $2 \%$ clay, $57 \%$ silt, $17 \%$ frags., $20 \%$ base sat. 
E2 5 to $38 \mathrm{~cm}$; pale brown (10YR 6/3) cherty silt loam; weak fine granular structure; friable; clear smooth boundary; $46 \%$ sand, $7 \%$ clay, $47 \%$ silt, $29 \%$ frags., $15 \%$ base sat.

EB $\quad 38$ to $48 \mathrm{~cm}$; light yellowish brown (10YR 6/4) cherty silt loam; weak medium subangular blocky structure; friable; gradual wavy boundary; $32 \%$ sand, $4 \%$ clay, $64 \%$ silt, $29 \%$ frags., $23 \%$ base sat.

BE $\quad 48$ to $55 \mathrm{~cm}$; yellowish red (5YR 5/6) cherty silt loam; weak medium subangular blocky structure; friable; gradual wavy boundary; $33 \%$ sand, $7 \%$ clay, $50 \%$ silt, $27 \%$ frags., $9 \%$ base sat.

Btl $\quad 55$ to $65 \mathrm{~cm}$; yellowish red (5YR 5/6) cherty silt loam; moderate medium subangular blocky structure; friable; few patchy clay films; clear wavy boundary. $33 \%$ sand, $9 \%$ clay, $58 \%$ silt, $32 \%$ frags., $11 \%$ base sat.

Bt2 65 to $102 \mathrm{~cm}$; red (2.5YR 4/8) cherty clay loam; strong medium subangular blocky structure; very firm; continuous clay films; clear wavy boundary; $24 \%$ sand, $27 \%$ clay, $49 \%$ silt, $14 \%$ frags., $11 \%$ base sat.

2Bt3 $102 \mathrm{~cm}$; red (2.5YR 4/8) clay.

\section{ANCIENT COLLUVIUM}

Soil Series No. 436

Location:

Classification:

Geomorphic Position:

Slope and Aspect:

Parent Material(s):

Vegetation:

Described By:

Date:
East Chestnut Ridge 'Site. E58850, N27630

Typic Hapludults; loamy-skeletal over clayey; siliceous, thermic

Topoinverted toeslope

5-6\% SW

Ancient colluvium over truncated Chepultepec residuum

Hardwoods

Lietzke

July 11, 1989

\section{Soil Description}

Oi 2 to $0 \mathrm{~cm}$; leaf litter.

Oe-Oa 0 to $5 \mathrm{~cm}$; dark reddish brown (5YR 2/2) hemic and sapric materials with dense root mat.

A 5 to $9 \mathrm{~cm}$; dark brown (1 OYR 3/3) extremely cherty silt loam; strong fine granular structure; very friable; common fine roots; 50 to $60 \%$ chert fragments; clear wavy boundary. 
E $\quad 9$ to $27 \mathrm{~cm}$; olive brown (2.5Y 4/4) extremely cherty silt loam; weak fine granular structure; very friable; common fine roots; 50 to $60 \%$ chert fragments; gradual wavy boundary.

Btl 27 to $50 \mathrm{~cm}$; light yellowish brown (1 OYR-2.5Y 6/4) extremely cherty silty clay loam; moderate medium subangular blocky structure: friable; few fine and few medium roots; 60 to $70 \%$ chert fragments: abrupt wavy boundary.

2Bt2 50 to $70 \mathrm{~cm}$; yellowish red (5YR 5/6) cherty silty clay loam or cherty clay; moderate medium subangular blocky structure; firm; few fine roots; 25 to $35 \%$ chert fragments; gradual wavy boundary.

2Bt3 70 to $92 \mathrm{~cm}$; yellowish red (5YR 5/6) and red (2.5YR 4/8) cherty clay; moderate medium subangular blocky structure; very firm; few yellowish saprolite splotches in lower part; few fine roots; 25 to $35 \%$ chert fragments; gradual wavy boundary.

2BC 92 to $135 \mathrm{~cm}$; yellowish red (5YR 5/6) and red (2.5YR 4/6) cherty silty clay loam; weak medium subangular blocky structure; firm; common yellowish saprolite splotches; few fine roots; 25 to $35 \%$ chert fragments.

NOTES: Most of the surficial colluvium is from older and younger materials that have been reworked and spread over a truncated residual surface. The abrupt boundary at $50 \mathrm{~cm}$ indicates the presence of a discontinuity. Depth of ancient colluvium in mapping varied from less than $50 \mathrm{~cm}$ to more than $100 \mathrm{~cm}$.

\section{DOLNE SOILS}

\section{Soil Series No. 437}

Location:

Classification:

Geomorphic Position:

Slope and Aspect:

Parent Material(s):

Vegetation:

Described By:

Date:

Highest hill on south side of Walker Branch Watershed. The pit is located just outside the watershed boundary. Approx 200' grid south of grid point 6338, 5734. Typic Fragiudults; fine-silty over loamy-skeletal; siliceous, thermic

Within a very shallow sidehill doline

3 to $4 \%$ S

Loess over ancient colluvium

Pine and oaks of old field succession

Lietzke

April 27, 1989

Soil Description

- 3 to $0 \mathrm{~cm}$; oak leaf litter.

A $\quad 0$ to $7 \mathrm{~cm}$; grayish brown (2.5Y 5/2) silt loam; moderate fine granular structure; very friable; many fine and common medium roots; 1 to $5 \%$ chert fragments; clear wavy boundary. 
E $\quad 7$ to $21 \mathrm{~cm}$; olive; (5Y 5/3) silt loam; weak fine granular structure; very friable: few fine and common medium roots; 2 to $5 \%$ fragments; gradual wavy boundary.

EB 21 to $36 \mathrm{~cm}$; yellowish brown (1 OYR 5/4) silt loam; 'weak fine subangular blocky structure; very friable; few fine and common medium roots: 2 to $5 \%$ fragments; clear wavy boundary.

Btl 36 to $50 \mathrm{~cm}$; dark yellowish brown (10YR 4/6) light silty clay loam; moderate fine subangular blocky structure; very friable; few fine and medium roots; 2 to $5 \%$ fragments; gradual wavy boundary.

Bt2 50 to $65 \mathrm{~cm}$; dark yellowish brown (1OYR 4/6) cherty silty clay loam; weak fine subangular blocky structure; friable; dark yellowish brown (1 OYR 4/4) clay on ped surfaces; few fine roots; 15 to $30 \%$ fragments; gradual wavy boundary. (Mixed zone between loess and colluvium.)

2Bt3 65 to $87 \mathrm{~cm}$; strong brown (7.5YR 4/6) extremely cherty silty clay loam; weak fine subangular blocky structure; friable; few fine roots; 50 to $70 \%$ fragments: abrupt wavy boundary.

2Bx 87 to $94 \mathrm{~cm}$; pale brown (1 OYR $6 / 3$ ) extremely cherty silt loam to silty clay loam, with dark yellowish brown (1 OYR 4/6) clay coatings; massive?; firm and brittle; no roots; 50 to $70 \%$ fragments.

NOTES: Depth of pit $94 \mathrm{~cm}$. Could not auger any deeper.

Soil Series No. 438

Location:

Classification:

Geomorphic Position:

Slope and Aspect:

Parent Material(s):

Vegetation:

Described By:

Date:

ORR. Intersection of Gasline Road and Telephone line.

First pit south of intersection. E30000, N26000

Typic Hapludults; fine-silty, mixed or siliceous, thermic Bottom of partially breached upland karst depression

2 to $5 \% \mathrm{~S}$

Loess over ancient cherty fragipan paleosol

Hardwoods

Lietzke

April 22, 1988

Soil Description

Oi $\quad 5$ to $0 \mathrm{~cm}$; leaf litter and root mat.

C $\quad 0$ to $10 \mathrm{~cm}$; yellowish red (5YR 4/6) cherty clay loam; moderate fine granular structure; very friable; common fine and medium roots; many pores; 15 to $25 \%$ chert fragments; abrupt wavy boundary. (Overwash from pipeline construction.) 
A $\quad 10$ to $20 \mathrm{~cm}$; olive brown (2.5Y 4/3) silt loam; weak fine granular structure; very friable; common fine and medium roots; many pores; 5 to $10 \%$ chert fragments; clear wavy boundary.

E 20 to $33 \mathrm{~cm}$; light olive brown (2.5Y 5/4) silt loam: weak medium subangular blocky structure; very friable; common fine and medium roots; many pores; less than $5 \%$ chert fragments; clear wavy boundary.

Btl $\quad 33$ to $67 \mathrm{~cm}$; light olive brown (2.5Y 5/6) silt loam-silty clay loam; moderate medium subangular blocky structure: very friable; common fine and medium roots; many pores; less than $5 \%$ chert fragments; clear wavy boundary. (Base of loess)

Bt2 67 to $79 \mathrm{~cm}$; mixed light olive brown (2.5Y 5/4) and yellowish brown (1 OYR 5/4) cherty silty clay loam; weak medium subangular blocky structure; friable; few fine roots; common pores; 15 to $25 \%$ chert fragments; gradual wavy boundary. (Mixed zone)

Agb 79 to $90 \mathrm{~cm}$; light brownish gray (2.5Y 6/2) cherty silt loam or cherty silty clay loam; weak medium subangular blocky structure; friable; few fine roots; common pores: 25 to $35 \%$ chert fragments; gradual wavy boundary. (Old A horizon)

Egb 90 to $104 \mathrm{~cm}$; light brownish gray (2.5Y 6/2) very cherty silt loam or very cherty silty clay loam; weak medium subangular blocky structure; friable; few light olive brown (2.5Y 5/6) drainage mottles; few fine roots; common pores; 30 to $50 \%$ chert fragments; gradual wavy boundary.

Btgb 104 to $115 \mathrm{~cm}$; light brownish gray (2.5Y 6/2) extremely cherty silty clay loam; weak medium subangular blocky structure tending towards massive; very firm; cracks, ped faces, and pores coated with yellowish brown (10YR 5/8) and strong brown (7.5YR 4/6) iron plasma; few fine roots; few pores; greater than $50 \%$ chert fragments.

NOTES: - Standing water in pit at $115 \mathrm{~cm}$, probably perched.

- Parent materials are recent subsoil overwash, thin cherty slope wash (A horizon), over loess over cherty slope wash, over ancient cherty paleosol similar to the ancient cherty No. 436 paleosol in the next pit to the south.

Soil Series No. 439

Location:

Classification:

Geomorphic Position:

Slope and Aspect:

Parent Material(s):

Vegetation:

Described By:

Date:
East Chestnut Ridge, small wet doline with well No. 571. E58940, N27660

Aeric or Typic Ochraquults; fine-silty, siliceous, thermic Bottom of clay-plugged doline

$2 \%$

Slope wash and loess over cherty colluvium

Hardwoods

Lietzke

July 11, 1989 
Soil Description

O 2 to $0 \mathrm{~cm}$; leaf litter.

A $\quad 0$ to $12 \mathrm{~cm}$ : black (10YR 2/1) silt loam; strong medium granular structure; very friable; many fine and common medium roots; 5 to $10 \%$ chert fragments; clear wavy boundary.

Btl 12 to $35 \mathrm{~cm}$; olive (5Y 5/4) heavy silt loam; moderate medium subangular blocky structure; friable; slightly sticky; many medium and common fine roots; 5 to $10 \%$ chert fragments; clear wavy boundary.

Bt2 35 to $63 \mathrm{~cm}$; olive ( $5 Y$ 5/3) silty clay loam; moderate medium subangular blocky structure; firm; slightly sticky; grayish brown (1 OYR 5/2) coatings on ped faces; few medium and common fine roots; 5 to $10 \%$ chert fragments; clear wavy boundary.

Ab $\quad 63$ to $82 \mathrm{~cm}$ : grayish brown (1 OYR $5 / 2$ ) very cherty silty clay loam; moderate fine subangular blocky structure; firm; slightly sticky; dark gray (10YR 4/1) ped coatings; 40 to $50 \%$ chert fragments; clear wavy boundary.

Eg 82 to $103 \mathrm{~cm}$ : gray (1 OYR 6/1) very cherty silt loam; weak fine subangular blocky structure; friable with brittle areas; light yellowish brown (2.5Y 6/4) mottles and strong brown (7.5YR 5/6) iron streaks; few fine roots; 30 to $40 \%$ chert fragments; clear wavy boundary.

Btg 103 to $135 \mathrm{~cm}$; light gray (10YR 7/1) cherty silty clay loam; moderate medium subangular blocky structure; firm; slightly sticky; 20 to $35 \%$ chert fragments; clear wavy boundary.

Bg 135 to $145 \mathrm{~cm}$ : light gray (1 OYR 7/1) extremely cherty silt loam; friable; strong brown (7.5YR 5/6) iron streaks and stains.

NOTES: The well log of well No. 571 indicates the presence of a high silt content soil to a depth of about 5 feet. From 5 to about 20 feet the material is a gray cherty or very cherty clay loam colluvium. From 28 to 40 feet there is cherty or very cherty clay colluvium. From about 40 feet to 50 feet was clayey reddish saprolite, with gray streaks in flow zones. A dolomite fragment was encountered at a depth of 48 to 50 feet. The saprolite was very wet with red and gray colors. Below 52 feet the saprolite was redder and less wet, but had gray water flow streaks. The hole penetrated to 80 feet with auger refusal in oxidized and slightly leached dolomite fragments. The hole collapsed at about the 10 foot depth, the base of the first perched zone. 


\section{ANCIENT ALLUVIUM}

Soil Series No. 990

Location:

Walker Branch Watershed. Upper left part of seven fingered subwatershed in the only delineation of this soil. Approx. 100 feet grid east of grid point 7054,

Classification: 7658.

Geomorphic Position:

Rhodic Paleudults; clayey; kaolinitic, thermic

Slope and Aspect:

Ancient topographically inverted dissected terrace

Parent Material(s):

10 to $12 \%$ SE

Ancient alluvium

Vegetation:

Described By:

Date:

Pines and hardwoods of old field succession

Lietzke

May 22, 1989

Soil Description

O 2 to $0 \mathrm{~cm}$; leaf litter.

A $\quad 0$ to $3 \mathrm{~cm}$ : dark reddish brown (5YR 3/2) silty clay loam; moderate fine granular structure; very friable: few fine and few medium roots; 0 to $2 \%$ fragments; abrupt wavy boundary.

Ap 3 to $16 \mathrm{~cm}$; dark reddish brown (2.5YR 3/4) silty clay loam; weak fine subangular blocky structure; friable; few fine and few medium roots; 0 to $2 \%$ fragments; abrupt wavy boundary.

Bt 16 to $150 \mathrm{~cm}$; dark red (2.5YR 3/6) clay; strong fine subangular blocky structure; friable; no fragments.

Soil Series No. 991

Location:

Classification:

Geomorphic Position:

Slope and Aspect:

Parent Material(s):

Vegetation:

Described By:

Date:
Walker Branch Watershed in seven-fingered subwatershed of West Fork. Approx. 80 feet grid east of grid point 7318, 7658 .

Typic Paleudults; fine-silty, siliceous, thermic

Topographically inverted loess covered terrace $5 \%$ SW

Loess over old local alluvium over Chepultepec residuum

Pines and hardwoods of old field succession Lietzke

May 22, 1989 
Soil Description

O 2 to $0 \mathrm{~cm}$; leaf litter and root mat.

A $\quad 0$ to $4 \mathrm{~cm}$; very dark grayish brown (10YR 3/2) silt loam; moderate fine granular structure; very friable; many fine and few medium roots; 2 to $5 \%$ chert fragments; clear wavy boundary.

AP 4 to $15 \mathrm{~cm}$; dark brown (10YR 3/3) silt loam; weak fine granular structure; very friable; common fine and common medium roots; 2 to $5 \%$ chert fragments; clear wavy boundary.

EB 15 to $33 \mathrm{~cm}$; yellowish brown (10YR 5/4) silt loam; weak fine granular structure; very friable; very porous; common fine and common medium roots; 2 to $5 \%$ chert fragments; clear wavy boundary.

Btl 33 to $50 \mathrm{~cm}$; dark yellowish brown (1 OYR 4/6) heavy silt loam; moderate fine subangular blocky structure; very friable; few fine roots; 2 to $5 \%$ chert fragments; gradual wavy boundary.

Bt2 50 to $69 \mathrm{~cm}$; dark yellowish brown (1 OYR 4/6) silty clay loam; moderate fine subangular blocky structure; very friable; few fine roots: 2 to $5 \%$ chert fragments; gradual wavy boundary.

2Bt3 69 to $86 \mathrm{~cm}$; strong brown (7.5YR 5/6) silty clay loam; weak coarse subangular blocky structure; very friable; many soft red and dark red bodies where iron oxide is accumulating; few fine roots; 10 to $15 \%$ chert fragments; clear wavy boundary. (Perched water at base of horizon.) (Mixed zone of soil above and that beneath)

2Bt4 86 to $110 \mathrm{~cm}$; yellowish red (5YR 4/6) silty clay loam with yellowish brown mottles; 10 to $15 \%$ weathered chert. (augered)

2Bt5 110 to $160 \mathrm{~cm}$; red (2.5YR 4/8) silty clay loam; 10 to $15 \%$ weathered chert. Base of old alluvium and toeslope colluvium.

3Bt6 160 to $190 \mathrm{~cm}$; highly mottled red and yellowish brown clay. Chepultepec residuum.

Soil Series No. 994

Location:

Classification:

Geomorphic Position:

Slope and Aspect:

Parent Material(s):
ORR. Chestnut Ridge area in Roane County. Pit located between ,new borrow area and Reeves Road. E33950, N28150

Typic Paleudults; fine-loamy, siliceous, thermic Upper colluvial footslope $35 \%$ east

Mixture of ancient alluvium and toeslope colluvium over Copper Ridge residuum 
Vegetation:

Tulip poplar, redbud, dogwood, and pines of old field

Described By:

Date: succession

Lietzke

May 18, 1988

\section{Soil Description}

Oi 4 to $0 \mathrm{~cm}$; leaf litter.

Al 0 to $20 \mathrm{~cm}$; dark brown (7.5YR 3/2) silt loam; strong fine granular structure; very friable; many fine and medium roots; many pores; 10 to $15 \%$ chert fragments; many hard dark nodules; clear wavy boundary.

A2 20 to $34 \mathrm{~cm}$; dark brown (7.5YR 3/4) silt loam; moderate medium granular structure; very friable; many fine and medium roots; many pores; 10 to $15 \%$ chert fragments; many hard dark nodules; clear wavy boundary.

E $\quad 34$ to $57 \mathrm{~cm}$;' strong brown (7.5YR 4/6) cherty silt loam; weak fine subangular blocky structure: very friable; common fine and medium roots; many pores; 15 to $25 \%$ chert fragments; many hard dark nodules; clear wavy boundary.

BE 57 to $75 \mathrm{~cm}$; brown (7.5YR 4/4) cherty silt loam-cherty silty clay loam; moderate fine subangular blocky structure; very friable; few fine roots; many pores; 25 to $30 \%$ chert fragments; many hard dark nodules; clear wavy boundary.

Btl $\quad 75$ to $92 \mathrm{~cm}$; yellowish red (5YR 4/6) cherty silty clay loam; moderate medium and fine subangular blocky structure; very friable; few fine roots; many pores: 20 to $30 \%$ chert fragments: many hard dark nodules; gradual wavy boundary. Base of cherty alluvium and toeslope colluvium.

Bt2 92 to $129 \mathrm{~cm}$; mixed yellowish red (5YR 4/6) and red (2.5YR 4/8) cherty silty clay loam; moderate medium subangular blocky structure; friable: few fine roots; many pores; 30 to 35\% chert fragments; few hard dark nodules; clear irregular boundary. [mixed zone]

2Bt3 129 to $150 \mathrm{~cm}$; red (2.5YR 4/8) cherty clay; firm; few fine and medium roots; 20 to $30 \%$ chert fragments; no dark nodules. Copper Ridge residuum.

NOTES: Chert fragments in the upper $129 \mathrm{~cm}$ of the soil are 'soft and highly weathered. This soil, on east aspects, has an umbric epipedon. 
HOLOCENE ALLUVIUM

Soil Series No. 999

Pit No. 13 from TM-2968, Pages 79 to 82

Al 0 to $5 \mathrm{~cm}$; grayish brown (1 OYR $5 / 2$ ) silt loam; weak fine granular structure; very friable; abrupt smooth boundary: $24 \%$ sand, $7 \%$ clay, $69 \%$ sift, $11 \%$ frags., $43 \%$ base sat.

A2 5 to $23 \mathrm{~cm}$; grayish brown (10YR 5/2) cherty silt loam; weak fine granular structure; friable; abrupt smooth boundary; $25 \%$ sand, $4 \%$ clay, $71 \%$ silt, $17 \%$ frags., $57 \%$ base sat.

Btl 23 to $30 \mathrm{~cm}$; light yellowish brown (10YR 6/4) silt loam; moderate fine subangular blocky structure; friable; gradual wavy boundary; $25 \%$ sand, $9 \%$ clay, $65 \%$ silt, $12 \%$ frags., $17 \%$ base sat.?

Bt2 30 to $50 \mathrm{~cm}$; brownish yellow (1 OYR 6/8) silt loam; moderate medium subangular blocky structure; friable to firm; clear smooth boundary; $24 \%$ sand, $12 \%$ clay, $63 \%$ silt, $13 \%$ frags., $66 \%$ base sat.

Bt3 50 to $68 \mathrm{~cm}$; brownish yellow (1 OYR 6/8) silt loam: moderate medium subangular blocky structure; friable to firm; mottled, some brittle areas; abrupt smooth boundary; $22 \%$ sand, $17 \%$ clay, $60 \%$ silt, $7 \%$ frags., $48 \%$ base sat.

2c $\quad 68 \mathrm{~cm}$; extremely cherty silt loam.

Classification: Typic Hapludults; fine-loamy; siliceous, thermic.

Soil Series: No. 999

Note: Not a typical example of this soil.

MODERN ALLUVIUM

KNOX ALLUVIUM

Soil Series No. 981

Location:

Walker Branch Watershed approx. 60 feet grid east of grid point 6602, 6526, then about 20 feet grid north.

Classification: Close to remains of old cabin

Geomorphic Position: Slope and Aspect: Fluventic Dystrochrepts; loamy-skeletal, siliceous, thermic Floodplain Nearly level 
Parent Material(s):

Vegetation:

Described By:

Date:
Modern alluvium overlying an older truncated very cherty paleosol that either formed in Pleistocene alluvium or colluvium

Hardwoods

Lietzke

1986

Soil Description

A 0 to $8 \mathrm{~cm}$; very dark grayish brown (1 OYR 3/2) loam; moderate fine granular structure; very friable; common medium roots; $10 \%$ chert fragments; abrupt wavy boundary.

C 8 to $15 \mathrm{~cm}$; $60 \%$ dark brown (1 OYR $3 / 3$ ) and $40 \%$ brown (1 OYR $4 / 3$ ) sandy loam; massive and stratified; very friable; few fine roots; 10 to $15 \%$ chert fragments; abrupt wavy boundary.

$\mathrm{Ab} \quad 15$ to $30 \mathrm{~cm}$; dark brown (1 OYR 3/3) loam; weak fine granular structure; very friable; few fine roots; 5 to $10 \%$ chert fragments; clear wavy boundary.

Bwl 30 to $65 \mathrm{~cm}$; brown (10YR 4/3) cherty loam; weak fine subangular blocky structure; friable; few fine roots; 30 to $35 \%$ chert fragments; gradual wavy boundary.

Bw2 65 to $93 \mathrm{~cm}$ : dark yellowish brown (1 OYR 4/4) very cherty loam; weak medium subangular blocky structure; friable; no roots; 35 to $40 \%$ chert fragments; gradual wavy boundary.

Bw3 93 to $118 \mathrm{~cm}$; dark yellowish brown (1 OYR 4/6) very cherty loam-clay loam; weak medium subangular blocky structure; friable; 35 to $40 \%$ chert fragments; some manganese stains and charcoal fragments and a few yellowish red (5YR 5/6) peds.

Soil Series No. 982 (Site No. 6 W.B.)

Location:

Classification:

Physiography:

Geomorphic Position:

Slope and Aspect:

Parent Material(s):

Vegetation:

Described By:

Date:
Walker Branch Watershed near 320 meter marker above weirs

Typic Humaquepts; loamy-skeletal, siliceous, thermic Recently overwashed gravel bar in floodplain

Top of bar

3 to $4 \%$

Cherty alluvium from Knox

Hardwoods

Lietzke

October 8, 1987 
A.3 SOIL CORRELATION FROM TM-2968 (Peters et al. 1970)

\begin{tabular}{|c|c|c|c|}
\hline Pito. & \multicolumn{2}{|c|}{ New soil no. Old name } & Comments \\
\hline 1 & 430 & Fullerton & $\begin{array}{l}\text { Hillside phase with } 50 \text { to } 80 \mathrm{~cm} \text { of colluvium } \\
\text { over Chepultepec residuum }\end{array}$ \\
\hline 2 & 430 & Bodine & $100 \mathrm{~cm}$ to discontinuity. Loamy-skeletal phase \\
\hline 3 & 434 & Fullerton & $\begin{array}{l}\text { Greater than } 100 \mathrm{~cm} \text { to discontinuity. Mottled } \\
\text { zone but no pale brown mottle and no evident } \\
\text { brittleness. Intergrade to No. } 430 \text { soils }\end{array}$ \\
\hline 4 & 408 & Fullerton & $\begin{array}{l}\text { Chepultepec soil form in residuum of chert } \\
\text { beds. (Inclusion in colluvial delineation.) }\end{array}$ \\
\hline 5 & 408 & Bodine & $\begin{array}{l}\text { Chepultepec soil formed in residuum of chert } \\
\text { beds. Upper } 60 \mathrm{~cm} \text { of soil is creep materials }\end{array}$ \\
\hline 6 & 434 & Bodine & Discontinuity at $130 \mathrm{~cm}$ \\
\hline 7 & 434 & Bodine & Discontinuity at $80 \mathrm{~cm}$ \\
\hline 8 & 402 & Fullerton & Good example of Chepultepec soil \\
\hline 9 & 430 & Bodine & Hillside phase with $72 \mathrm{~cm}$ to discontinuity \\
\hline 10 & 406 & Fullerton & Good example of Kingsport soil \\
\hline 11 & 433 & Claiborne & Typical morphology with thick, dark surface \\
\hline 12 & 981 & Lindside & Typical soil of the floodplain \\
\hline 13 & 999 & Tarklin & Fan terrace phase from local alluvium \\
\hline
\end{tabular}

Pit No. 1, Page 14, TM-2968

Description has been modified by using current horizon designations, lab data to verify soil textures, and changing depths from inches to centimeters.

02 to $0 \mathrm{~cm}$; hardwood litter, the lower part partially decomposed.

El $\quad 0$ to $8 \mathrm{~cm}$; grayish brown (2.5Y $5 / 2)$ cherty silt loam; weak fine granular structure; friable; clear smooth boundary; $36 \%$ sand, $2 \%$ clay, $62 \%$ silt, $24 \%$ frags., $16 \%$ base sat.

E2 8 to $25 \mathrm{~cm}$; light yellowish brown (1 OYR 6/4) very cherty silt loam; weak fine granular structure; friable; clear smooth boundary; $25 \%$ sand, $9 \%$ clay, $66 \%$ silt, $39 \%$ frags., $9 \%$ base sat. 
E3 25 to $45 \mathrm{~cm}$; light yellowish brown (10YR 6/4) very cherty sift loam; weak medium granular structure; friable; the lower part streaked with very pale brown (10YR 8/4); clear irregular boundary; $32 \%$ sand, $7 \%$ clay, $62 \%$ sand, $40 \%$ frags., $19 \%$ base sat.

Btl $\quad 45$ to $55 \mathrm{~cm}$; reddish yellow (7.5YR 6/6) very cherty silt loam; weak fine subangular blocky structure; firm to friable; few thin patchy clay films; clear irregular boundary; $31 \%$ sand, $9 \%$ clay, $60 \%$ silt, $47 \%$ frags., $11 \%$ base sat.

2Bt2 55 to $65 \mathrm{~cm}$; yellowish red (5YR 5/8) cherty silty clay loam; moderate medium subangular blocky structure; firm; continuous clay films; clear irregular boundary; $31 \%$ sand, $33 \%$ clay, $50 \%$ silt, $17 \%$ frags., $10 \%$ base sat.

2Bt3 65 to $115 \mathrm{~cm}$; red (2.5YR 5/8) clay; strong medium angular blocky structure; very firm; continuous clay films; $12 \%$ sand, $39 \%$ clay, $49 \%$ silt, $2 \%$ frags., $6 \%$ base sat.

Classification: Fragic Paleudults; loamy-skeletal, siliceous, thermic. Soil Series No. 430, skeletal, hillside phase.

Additional data for this soil is on pages 16,17 , and 18 of TM-2968.

Soil Pit No. 2, Pages 21-24 of TM-2968

- 1 to $0 \mathrm{~cm}$; hardwood litter, the lower part partially decomposed.

A $\quad 0$ to $5 \mathrm{~cm}$; very dark grayish brown (10YR 3/2) cherty silt loam: weak medium granular structure; friable; abrupt smooth boundary: $36 \%$ sand, $2 \%$ clay, $62 \%$ silt, $19 \%$ frags., $33 \%$ base sat.

EI $\quad 5$ to $15 \mathrm{~cm}$ : pale brown (1 OYR 6/3) cherty silt loam; weak fine granular structure; friable; clear smooth boundary; $24 \%$ sand, $14 \%$ clay, $61 \%$ silt, $27 \%$ frags., $10 \%$ base sat.

E2 15 to $50 \mathrm{~cm}$ : light yellowish brown (1 OYR 6/4) cherty silt loam; weak fine granular structure; friable; clear smooth boundary; $11 \%$ sand, $4 \%$ clay, $84 \%$ silt, $25 \%$ frags., $17 \%$ base sat.

Btl $\quad 50$ to $68 \mathrm{~cm}$; reddish yellow (7.5YR 6/6) very cherty silt loam; moderate medium subangular blocky structure; friable; few patchy clay films; gradual smooth boundary: $37 \%$ sand, $7 \%$ clay, $56 \%$ silt, $51 \%$ frags., $15 \%$ base sat.

Bt2 68 to $90 \mathrm{~cm}$ : reddish yellow (7.5YR 6/6) very cherty silt loam; moderate medium subangular blocky structure; friable; few thin patchy reddish yellow (5YR 6/8) clay films; gradual wavy boundary; $13 \%$ sand, $13 \%$ clay, $75 \%$ silt, $16 \%$ base sat. 
NOTE: Additional examination of this pit in 1989 showed a discontinuity at about $100 \mathrm{~cm}$ to the clayey Chepultepec residuum beneath.

Pit No. 3 from TM-2968, Pages 25-28

$0 \quad 3$ to $0 \mathrm{~cm}$; hardwood litter, the lower part partially decomposed.

El $\quad 0$ to $5 \mathrm{~cm}$; grayish brown (10YR 5/2) cherty silt loam; weak fine granular structure: friable; clear smooth boundary; $41 \%$ sand, $2 \%$ clay, $57 \%$ silt, $17 \%$ frags., $20 \%$ base sat.

E2 5 to $38 \mathrm{~cm}$; pale brown (1 OYR 6/3) cherty silt loam; weak fine granular structure; friable; clear smooth boundary; $46 \%$ sand, $7 \%$ clay, $47 \%$ silt, $29 \%$ frags., $15 \%$ base sat.

EB $\quad 38$ to $48 \mathrm{~cm}$; light yellowish brown (1 OYR 6/4) cherty silt loam; weak medium subangular blocky structure; friable; gradual wavy boundary; $32 \%$ sand, $4 \%$ clay, $64 \%$ silt, $29 \%$ frags., $23 \%$ base sat.

BE $\quad 48$ to $55 \mathrm{~cm}$ : yellowish red (5YR 5/6) cherty silt loam; weak medium subangular blocky structure; friable; gradual wavy boundary; $33 \%$ sand, $7 \%$ clay, $50 \%$ silt, $27 \%$ frags., $9 \%$ base sat.

Btl $\quad 55$ to $65 \mathrm{~cm}$; yellowish red (5YR 5/6) cherty silt loam; moderate medium subangular blocky structure; friable; few patchy clay films; clear wavy boundary: $33 \%$ sand, $9 \%$ clay, $58 \%$ silt, $32 \%$ frags., $11 \%$ base sat.

Bt2 65 to $102 \mathrm{~cm}$; red (2.5YR 4/8) cherty clay loam; strong medium subangular blocky structure; very firm; continuous clay films; clear wavy boundary; $24 \%$ sand, $27 \%$ clay, $49 \%$ silt, $14 \%$ frags., $11 \%$ base sat.

2Bt3 $102 \mathrm{~cm}$; red (2.5YR 4/8) clay.

Classification: Typic Paleudults; fine-loamy, siliceous, thermic.

Soil Series: No. 434 (Minvale)

Pi No. 4 from TM-2968, Pages 31 to 35

$0 \quad 2$ to $0 \mathrm{~cm}$; hardwood litter, the lower part partially decomposed.

A $\quad 0$ to $8 \mathrm{~cm}$; dark grayish brown (1 OYR 4/2) very cherty silt loam; weak fine granular structure; friable: clear smooth boundary; $47 \%$ sand, $4 \%$ clay, $49 \%$ silt, $44 \%$ frags., $40 \%$ base sat.

El $\quad 8$ to $33 \mathrm{~cm}$ : pale brown (1 OYR 6/3) very cherty silt loam; weak medium granular structure; friable; clear smooth boundary; $34 \%$ sand, $12 \%$ clay, $54 \%$ silt, $44 \%$ frags., $6 \%$ base sat. 
E2 33 to $43 \mathrm{~cm}$; light yellowish brown (10YR 6/4) very cherty silt loam; weak fine granular structure; friable; abrupt smooth boundary: $31 \%$ sand, $9 \%$ clay, $60 \%$ silt, $40 \%$ frags., $11 \%$ base sat.

EB $\quad 43$ to $50 \mathrm{~cm}$; strong brown (7.5YR 5/6) extremely cherty silt loam; weak fine subangular blocky structure; friable; clear smooth boundary; $28 \%$ sand, $9 \%$ clay, $63 \%$ silt, $53 \%$ frags., $5 \%$ base sat.

Btl $\quad 50$ to $69 \mathrm{~cm}$; yellowish red (5YR 5/6) cherty silty clay; weak medium subangular blocky structure; firm; patchy clay films: gradual smooth boundary; $19 \%$ sand, $40 \%$ clay, $40 \%$ silt, $27 \%$ frags., $7 \%$ base sat.

Bt2 69 to $90 \mathrm{~cm}$; red (2.5YR 5/8) extremely cherty clay variegated with reddish yellow (7.5YR 6/8); strong medium subangular blocky structure; firm; continuous clay films; $19 \%$ sand, $49 \%$ clay, $33 \%$ silt, $65 \%$ frags., $8 \%$ base sat.

Classification: Typic Paleudults; clayey-skeletal, kaolinitic, thermic.

Soil Series: No. 408.

Pit No. 5 from TM-2968, Pages 37 to 40

- 3 to $0 \mathrm{~cm}$; hardwood litter, lower part partially decomposed.

A $\quad 0$ to $8 \mathrm{~cm}$ : dark grayish brown (1 OYR 4/2) cherty loam; moderate fine granular structure; friable; clear smooth boundary; $47 \%$ sand, $4 \%$ clay, $49 \%$ silt, $27 \%$ frags., $34 \%$ base sat.

El 8 to $20 \mathrm{~cm}$; brown (10YR 5/3) cherty loam; weak fine and medium granular structure; friable, clear smooth boundary; $47 \%$ sand, $12 \%$ clay, $41 \%$ sift, $34 \%$ frags., $16 \%$ base sat.

E2 20 to $60 \mathrm{~cm}$; light yellowish brown (1 OYR 6/4) very cherty loam; weak fine and medium granular structure; friable; clear smooth boundary; $49 \%$ sand, $9 \%$ clay, $41 \%$ silt, $40 \%$ frags., $16 \%$ base sat.

BE $\quad 60$ to $73 \mathrm{~cm}$; reddish yellow (5YR 6/8) extremely cherty loam; friable; clear wavy boundary; $38 \%$ sand, $20 \%$ clay, $43 \%$ silt, $65 \%$ frags., $10 \%$ base sat.

Btl $\quad 73$ to $163 \mathrm{~cm}$ : yellowish red (5YR 5/8) 'very cherty clay loam; strong medium angular blocky structure; very firm; continuous clay films; $25 \%$ sand, $38 \%$ clay, $37 \%$ silt, $57 \%$ frags., $8 \%$ base sat.

Classification: Typic Paleudults; clayey-skeletal, kaolinitic, thermic. (This profile was not described deep enough to get into the clayey argillic beneath. The upper $60 \mathrm{~cm}$ of the soil formed in creep materials.)

Soil Series: No. 408. 
Pit No. 6 from TM-2968, Pages 41 to 44

O 3 to $0 \mathrm{~cm}$; hardwood litter, the lower part partially decomposed.

.A $\quad 0$ to $8 \mathrm{~cm}$; very dark grayish brown (1 OYR $3 / 2$ ) cherty silt loam; weak fine granular structure; friable; abrupt smooth boundary; $20 \%$ sand, $2 \%$ clay, $78 \%$ silt, $33 \%$ frags., $19 \%$ base sat.

E $\quad 8$ to $30 \mathrm{~cm}$; pale brown (10YR 6/3) cherty silt loam; weak fine and medium granular structure; friable: clear smooth boundary; $19 \%$ sand, $7 \%$ clay, $75 \%$ silt, $24 \%$ frags., $6 \%$ base sat.

EB $\quad 30$ to $45 \mathrm{~cm}$; light yellowish brown (1 OYR 6/4) cherty silt loam; weak fine granular structure; friable; clear smooth boundary; $19 \%$ sand, $7 \%$ clay, $75 \%$ silt, $29 \%$ frags., $15 \%$ base sat.

BE $\quad 45$ to $65 \mathrm{~cm}$ : strong brown (7.5YR 5/6) cherty silt loam; weak fine and medium subangular blocky structure; friable; pockets of pale brown (10YR 6/3) around fragments and roots; few patchy clay films; clear smooth boundary; $21 \%$ sand, $12 \%$ clay, $68 \%$ silt, $25 \%$ frags., $10 \%$ base sat.

Btl $\quad 65$ to $85 \mathrm{~cm}$; yellowish red (5YR 5/8) very cherty silt loam; weak medium subangular blocky structure; firm to friable; common clay films; clear smooth boundary; $16 \%$ sand, $17 \%$ clay, $66 \%$ silt, $41 \%$ frags., $7 \%$ base sat.

Bt2 85 to $105 \mathrm{~cm}$; red (2.5YR 4/8) very cherty silt loam; strong medium angular blocky structure; firm; continuous clay films; $14 \%$ sand, $25 \%$ clay, $61 \%$ silt, $41 \%$ frags., $6 \%$ base sat.

NOTE: The discontinuity to clayey residuum occurs at a depth of about $130 \mathrm{~cm}$.

Classification: Typic Paleudults; fine-loamy, siliceous, thermic.

Soil Series: No. 434 (Minvale)

Pi No. 7 from TM-2968, Pages 47 to 50

01 to $0 \mathrm{~cm}$; the surface litter has been burned.

A $\quad 0$ to $33 \mathrm{~cm}$; light brownish gray (10YR 6/2) very cherty sift loam; weak fine granular structure; friable; clear smooth boundary; $24 \%$ sand, $4 \%$ clay, $71 \%$ silt, $43 \%$ frags., $30 \%$ base sat.

Bt $\quad 33$ to $43 \mathrm{~cm}$; brown (10YR 5/3) cherty silt loam, with a few pockets of strong brown (7.5YR 5/6) and pale brown (1 OYR 6/3); weak medium granular structure; friable; clear smooth boundary; $16 \%$ sand, $20 \%$ clay, $64 \%$ sift, $29 \%$ frags., $14 \%$ base sat. 
2E1 43 to $55 \mathrm{~cm}$; yellowish red ( 5 YR $5 / 6)$ cherty silt loam; weak medium subangular blocky structure; friable; patchy clay films; clear smooth boundary; $19 \%$ sand, $9 \%$ clay, $72 \%$ silt, $26 \%$ frags., $15 \%$ base sat.

2E2 55 to $65 \mathrm{~cm}$ : yellowish red (5YR 5/8) cherty silt loam; weak medium subangular blocky structure; friable; continuous clay films; clear smooth boundary; $13 \%$ sand, $9 \%$ clay, $77 \%$ silt, $32 \%$ frags., $27 \%$ base sat.

2B't $\quad 65$ to $80 \mathrm{~cm}$; red (2.5YR 4/8) cherty silty clay loam: strong medium angular blocky structure; firm; continuous clay films; clear smooth boundary; $13 \%$ sand, $35 \%$ clay, $51 \%$ silt, $23 \%$ frags., $27 \%$ base sat.

3B't 80 to $123 \mathrm{~cm}$; red (2.5YR 4/8) clay. (This discontinuity to the clayey residuum was noted in 1989.)

Classification: Typic Paleudults; fine-loamy, siliceous, thermic.

Soil Series: No. 434

Pit No. 8 from TM-968, Pages 53 to 56'

O 3 to $0 \mathrm{~cm}$; hardwood litter, the lower part partially decomposed.

EI $\quad 0$ to $25 \mathrm{~cm}$; pale yellow (2.5Y $7 / 4)$ cherty silt loam; weak fine granular structure; friable; clear smooth boundary; $22 \%$ sand, $7 \%$ clay, $72 \%$ silt, $27 \%$ frags., $6 \%$ base sat.

EB 25 to $85 \mathrm{~cm}$; pale yellow (2.5Y 7/4) silt loam; weak 'fine granular structure; friable; abrupt smooth boundary; $14 \%$ sand, $30 \%$ clay, $56 \%$ silt, $11 \%$ frags., $2 \%$ base sat.

BE $\quad 35$ to $40 \mathrm{~cm}$; strong brown (7.5YR 5/6) silty clay loam; weak medium subangular blocky structure; friable to firm; few clay films; clear smooth boundary; $15 \%$ sand, $28 \%$ clay, $58 \%$ silt, $8 \%$ frags, $4 \%$ base sat.

Btl $\quad 40$ to $50 \mathrm{~cm}$ : yellowish red (5YR 5/8) clay; moderate medium subangular blocky structure; firm; common clay films; clear smooth boundary; $8 \%$ sand, $64 \%$ clay, $28 \%$ sift, $4 \%$ frags., $3 \%$ base sat.

Bt2 $\quad 50$ to $100 \mathrm{~cm}$; yellowish red (5YR 5/8) clay; strong medium subangular blocky structure; firm to very firm; continuous clay films; $4 \%$ sand, $75 \%$ clay, $22 \%$ sift, $2 \%$ frags., $1 \%$ base sat.

Classification: Typic Paleudults; clayey, kaolinitic, thermic.

Soil Series: No. 402, Excellent example of a Chepuitepec soil 
Pit No. 9 from TM-2968_Pages 57 to 60

03 to $0 \mathrm{~cm}$; hardwood litter, with a very thin partially decomposed layer.

A $\quad 0$ to $8 \mathrm{~cm}$; very dark gray (10YR 3/1) extremely cherty silt loam. (This layer consists mostly of chert fragments.) $35 \%$ sand, $4 \%$ clay, $61 \%$ silt, $84 \%$ frags., $4 \%$ base sat.

E $\quad 8$ to $50 \mathrm{~cm}$; pale yellow (2.5Y $7 / 4)$ very cherty silt loam; weak medium granular structure; friable; clear smooth boundary; $31 \%$ sand, $14 \%$ clay, $55 \%$ silt, $41 \%$ frags., $8 \%$ base sat.

Btl $\quad 50$ to $73 \mathrm{~cm}$; yellow (1 OYR 7/6) very cherty silt loam; weak medium to fine subangular blocky structure; friable: few patchy clay films; clear wavy boundary; $25 \%$ sand, $17 \%$ clay, $58 \%$ silt, $51 \%$ frags., $3 \%$ base sat.

2Bt2 73 to $80 \mathrm{~cm}$; yellowish red (5YR 5/6) silty clay; moderate medium subangular blocky structure; firm; continuous clay films; clear smooth boundary; $11 \%$ sand, $43 \%$ clay, $46 \%$ silt, $6 \%$ frags., $2 \%$ base sat.

2Bt3 80 to $103 \mathrm{~cm}$; yellowish red (5YR 5/8) clay; strong medium angular blocky structure; very firm; continuous clay films; $4 \%$ sand, $72 \%$ clay, $24 \%$ silt, $3 \%$ frags., $3 \%$ base sat.

Classification: Fragic Paleudults; fine-loamy, siliceous, thermic.

Soil Series: Soil No. 430., hillside phase.

NOTES: A discontinuity to the underlying Chepultepec clayey residuum was noted in 1989 at a depth of $72 \mathrm{~cm}$.

Pit No. 10, from TM-2968, Pages 61 to 64

0 \& $\mathrm{A} \quad 0$ to $5 \mathrm{~cm}$; these layers have been almost destroyed by fire; $23 \%$ sand, $2 \%$ clay, $76 \%$ silt, $38 \%$ frags., $4 \%$ base sat.

E $\quad 5$ to $23 \mathrm{~cm}$; light yellowish brown (10YR 6/4) cherty silt loam; weak fine granular structure; friable; abrupt smooth boundary; $21 \%$ sand, $4 \%$ clay, $74 \%$ sift, $21 \%$ frags., $7 \%$ base sat.

BE 23 to $28 \mathrm{~cm}$; yellowish red (5YR 5/6) to strong brown (7.5YR 5/6) cherty silt loam: weak medium granular structure; friable; pockets of light yellowish brown (1 OYR 6/4); clear smooth boundary; $17 \%$ sand, $14 \%$ clay, $68 \%$ silt, $34 \%$ frags., $4 \%$ base sat.

Btl $\quad 28$ to $35 \mathrm{~cm}$; yellowish red (5YR 5/6) cherty silty clay; weak medium angular and subangular blocky structure; firm; patchy clay films; clear smooth boundary; $12 \%$ sand, $46 \%$ clay, $42 \%$ silt, $18 \%$ frags., $1 \%$ base sat. 
Bt2 35 to $50 \mathrm{~cm}$; red $(2.5 Y R ~ 4 / 8)$ clay; strong coarse angular blocky structure; firm or very firm; continuous clay films; highly weathered light gray chert; gradual smooth boundary; $8 \%$ sand, $55 \%$ clay, $37 \%$ silt, $10 \%$ frags., $2 \%$ base sat.

Bt3 50 to $73 \mathrm{~cm}$; red (2.5YR 4/8) variegated with yellow (10YR 7/8) cherty clay; strong coarse and medium angular blocky structure; very firm; continuous clay films; highly weathered light gray chert; gradual smooth boundary; $5 \%$ sand, $67 \%$ clay, $29 \%$ silt, $3 \%$ rags., $2 \%$ base sat.

BC $\quad 73$ to $105 \mathrm{~cm}$; prominently mottled red (2.5YR 4/8) and yellow (1 OYR 7/8) silty clay; strong coarse and medium angular blocky structure; very firm; continuous clay films; highly weathered light gray chert; $6 \%$ sand, $48 \%$ clay, $46 \%$ silt, $11 \%$ frags., $1 \%$ base sat.

Classification: Typic Hapludults; clayey, kaolinitic, thermic.

Soil Series: No. 406.

NOTE: Good example of a Kingsport soil.

Pit No. 11 from TM-2968, Pages 67 to 71

- 2 to $0 \mathrm{~cm}$; hardwood litter, the lower part partially decomposed.

Al $\quad 0$ to $5 \mathrm{~cm}$; dark brown (7.5YR 3/2) cherty silt loam; strong medium granular structure; friable; abrupt smooth boundary; $27 \%$ sand, $7 \%$ clay, $66 \%$ silt, $19 \%$ frags., $34 \%$ base sat.

A2 5 to $23 \mathrm{~cm}$; dark brown (7.5YR 4/2) cherty silt loam; weak medium granular structure; friable; clear smooth boundary; $26 \%$ sand, $7 \%$ clay, $67 \%$ silt, $20 \%$ frags., $55 \%$ base sat.

Btl $\quad 23$ to $38 \mathrm{~cm}$; strong brown (7.5YR 5/6) cherty silt loam; weak medium subangular blocky structure; friable; patchy clay films: clear smooth boundary; $22 \%$ sand, $12 \%$ clay, $66 \%$ silt, $17 \%$ frags., $29 \%$ base sat.

Bt2 38 to $60 \mathrm{~cm}$; strong brown (7.5YR 5/6) cherty silt loam; moderate fine and medium subangular blocky structure; friable; common clay films; clear smooth boundary; $18 \%$ sand, $20 \%$ clay, $63 \%$ silt, $23 \%$ frags., $71 \%$ base sat.

2Bt3 60 to $80 \mathrm{~cm}$; yellowish red (5YR 4/8) cherty silt loam; moderate medium subangular blocky structure; firm; patchy clay films; gradual smooth boundary; $18 \%$ and $17 \%$ clay, $65 \%$ silt, $22 \%$ frags., $58 \%$ base sat.

2Bt4 80 to $110 \mathrm{~cm}$; yellowish red (5YR 4/8) cherty silt loam; strong medium subangular blocky structure: firm; patchy clay films; $19 \%$ sand, $20 \%$ clay, $61 \%$ silt, $34 \%$ frags., $27 \%$ base sat. 
Classification: Humic Hapludults; fine-loamy, siliceous, thermic.

Soil Series: No. 433

Pit No. 12 from TM-2968, Pages 73 to 76

Al $\quad 0$ to $5 \mathrm{~cm}$; very dark grayish brown (10YR 3/2) cherty silt loam; strong medium granular structure; very friable; abrupt smooth boundary; $24 \%$ sand, $14 \%$ clay, $61 \%$ silt, $27 \%$ rags., $56 \%$ base sat.

A2 5 to $18 \mathrm{~cm}$; dark brown (10YR 4/3) cherty silt loam; weak fine granular structure; friable; clear smooth boundary; $40 \%$ sand, $9 \%$ clay, $51 \%$ silt, $35 \%$ frags., $55 \%$ base sat.

AC $\quad 18$ to $38 \mathrm{~cm}$; dark grayish brown (1 OYR 4/2) very cherty sift loam; weak fine granular structure; firm to friable; clear smooth boundary; $29 \%$ sand, $12 \%$ clay, $59 \%$ silt, $38 \%$ frags., $47 \%$ base sat.

$\mathrm{Cl} \quad 38$ to $55 \mathrm{~cm}$; yellowish brown (1 OYR 5/4) extremely cherty loam; weak fine granular structure; friable; gradual smooth boundary; $50 \%$ sand, $14 \%$ clay, $36 \%$ silt, $64 \%$ frags., $59 \%$ base sat.

c2 55 to $88 \mathrm{~cm}$; yellowish brown (1 OYR $5 / 8$ ) extremely cherty sandy loam; weak fine subangular blocky structure; friable; $64 \%$ sand, $17 \%$ clay, $19 \%$ silt, $64 \%$ frags., $46 \%$ base sat.

Classification: Typic Udifluvents; loamy-skeletal, siliceous, thermic.

Soil Series: No. 981

Pit No. 13 from TM-2968, Pages 79 to 82

Al $\quad 0$ to $5 \mathrm{~cm}$; grayish brown (10YR 5/2) silt loam; weak fine granular structure; very friable; abrupt smooth boundary; $24 \%$ sand, $7 \%$ clay, $69 \%$ silt, $11 \%$ frags., $43 \%$ base sat.

A2 5 to $23 \mathrm{~cm}$; grayish brown (1 OYR 5/2) cherty silt loam; weak fine granular structure; friable; abrupt smooth boundary; $25 \%$ sand, $4 \%$ clay, $71 \%$ silt, $17 \%$ frags., $57 \%$ base sat.

Btl 23 to $30 \mathrm{~cm}$; light yellowish brown (1 OYR 6/4) silt loam; moderate fine subangular blocky structure; friable; gradual wavy boundary; $25 \%$ sand, $9 \%$ clay, $65 \%$ sift, $12 \%$ frags., $17 \%$ base sat.?

Bt2 30 to $50 \mathrm{~cm}$; brownish yellow (1 OYR 6/8) silt loam; moderate medium subangular blocky structure; friable to firm; clear smooth boundary; $24 \%$ sand, $12 \%$ clay, $63 \%$ silt, $13 \%$ frags., $66 \%$ base sat. 
Bt3 50 to $68 \mathrm{~cm}$; brpwnish yellow (1 OYR 6/8) silt loam; moderate medium subangular blocky structure; friäble to firm; mottled, some brittle areas; abrupt smooth boundary; $22 \%$ sand, $17 \%$ clay, $60 \%$ silt, $7 \%$ frags., $48 \%$ base sat.

2c $\quad 68 \mathrm{~cm}$; extremely cherty silt loam.

Classification: Typic Hapludults; fine-loamy; siliceous, thermic.

Soil Series: No. 999

NOTE: Not a typical example of this soil. 
$=$

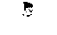




\section{INTERNALDISTRIBUTION}

1. S. I. Auerbach, Building 1505, Mail Stop 6036

2. L. D. Bates, Building K-I 001, Mail Stop 7169

3. H. L. Boston, Building 7078-A, Mail Stop 6402

4. J. W. Chason, Building 1505, Mail Stop 6036

5. R. B. Clapp, Building 1505, Mail Stop 6036

6. L. W. Cooper, Building 1505, Mail Stop 6036

7. J. H. Cushman, Building 1503, Mail Stop 6352

8. R. Dreier, Building 1503, Mail Stop 6352

9. N. T. Edwards, Building 1506, Mail Stop 6034

10. N. D. Farrow, Building 3504, Mail Stop 6317

11. T. A. Fontaine, Building 1505, Mail Stop 6036

12. D. E. Fowler, Building 1505, Mail Stop 6035

13. C. W. Francis, Building 3504, Mail Stop 6317

14. C. T. Garten, Building 1505, Mail Stop 6036

15. C. W. Gehrs, Building 1505, Mail Stop 6036

16. P. J. Hanson, Building 1506, Mail Stop 6034

17. R. D. Hatcher, Building 1503, Mail Stop 6352

18. S. G. Hildebrand, Building 1505, Mail Stop 6037

19-73. M. A. Huston, Building 1505, Mail Stop 6036

74. P. M. Jardine, Building 1505, Mail Stop 6036

75. J. D. Joslin, Building 1506, Mail Stop 6034

76. P. Kanciruk, Building 0907, Mail Stop 6490

77. R. H. Ketelle, Building $4500 \mathrm{~N}$, Mail Stop 6165

78. B. L. Kimmel, Building 7078-A, Mail Stop 6402

79. I. L. Larsen, Building 1505, Mail Stop 6036

80. P. J. Lemiszki, Büilding 1503, Mail Stop 6352

81-90. D. A. Lietzke, Building 1505, Mail Stop 6036

91. J. M. Loar, Building 1504, Mail Stop 6351

92. R. J. Luxmoore, Building 1505, Mail Stop 6036

93. L. K. Mann, Building 1505, Mail Stop 6036

94. W. M. McMaster, Building 1503, Mail Stop 6352

95. P. J. Mulholland, Building 1505, Mail Stop 6036

96. R. J. Norby, Building 1506, Mail Stop 6034

97. E. G. O'Neill, Building 1506, Mail Stop 6034

98. A. V. Palumbo, Building 1505, Mail Stop 6036

99. P. D. Parr, Building. 1506, Mail Stop 6034

100. B. S. Pedersen, Building 1506, Mail Stop 6034

101. W. M. Post, Building 1000, Mail Stop 6335

102. D. E. Reichle, Building $4500 N$, Mail Stop 6253

103. F. E. Sharples, Building 1505, Mail Stop 6036

104. D. S. Shriner, Building 1505, Mail Stop 6036

105. D. K. Solomon, Building 1503, Mail Stop 6352

106. S. H. Stow, Building 1505, Mail Stop 6036

107. J. Switek, Building 3504, Mail Stop 6317

108. S. P. Timmins, Building 1505, Mail Stop 6036

109. D. E. Todd, Building 1505, Mail Stop 6036

110: R. R. Turner, Building 1505, Mail Stop 6036 
INTERNAL DISTRIBUTION (Continued)

111. R. S. Turner, Building 1505, Mail Stop 6638

112-113. Central Research Library, Building 4500 N, Mail Stop 6191

114-128. ESD Library, Building 1505, Mail Stop 6635

129-I 30. Laboratory Records Department, Bullding 4500N, Mail Stop 6285

131. Laboratory Records, ORNL-RC, Building 4500N, Mail Stop 6285

132. ORNL Patent Section, Building 4500N, Mail Stop 6285

133. ORNL Y-I 2 Technical Library, Building 971 1-1, Mail Stop 8104 


\section{EXTERNAL DISTRIBUTION}

134. J. W. Elwood, Office of Energy Research, ER-74, U.S. Department of Energy, Washington, DC 26845

135. R. N. Farvolden, Professor, Department of Earth Sciences, University of Waterloo, Waterloo, Ontario N2L 3G1, Canada

136. D. W. Freckman, Director, College of Natural Resources, 101 Natural Resources Building, Colorado State University, Fort Collins, CO 86523

137. D. Genereux, Department of Civil Engineering, Building 48, Room 419, Massachusetts Institute of Technology, Cambridge, MA 02139

138. R. C. Harriss, Institute for the Study of Earth, Oceans, and Space, Science and Engineering Research Building, University of New Hampshire, Durham, NH 03824

139. D. W. Johnson, Biological Sciences Center, Desert Research Institute, P. 0. Box 60220, Reno, NV 89506-0220

140. G. Y. Jordy, Director, Office of Program Analysis, Office of Energy Research, ER-30, G-226, U.S. Department of Energy, Washington, DC 20545

141. C. D. Jorgensen, Environmental Sciences Division, ER-74, Office of Health and Environmental Research, U.S. Department of Energy, Washington, DC 20585

142. J. D. O'Dell, Plant and Soil Science Department, The University of Tennessee, Knoxville, TN 37996-4500

143. R. H. Olsen, Professor, Microbiology and Immunology Department, University of Michigan, Medical Sciences II, \#5605, 1301 East Catherine Street, Ann Arbor, Ml 48109-0620

144. A. Patrinos, Director, Environmental Sciences Division, Office of Health and Environmental Research, ER-74, U.S. Department of Energy, Washington, DC 20585

145. A. D. Steinman, Science Applications International Corporation, 10260 Campus Point Road, M/S C-2, San Diego, CA 92121-1578

146. H. Van Miegroet, Department of Forest Resources, Utah State University, Logan, UT 84322-5215

147. F. J. Wobber, Environmental Sciences Division, Office of Health and Environmental Research, ER-74, U.S. Department of Energy, Washington, DC 20585

148. Office of Assistant Manager for Energy Research and Development, U.S. Department of Energy Oak Ridge Operations, P. 0. Box 2001, Oak Ridge, TN 37831-8600

149-I 50. Office of Scientific and Technical Information, P. 0. Box 62, Oak Ridge, TN 37831 
5 